\author{
UNIVERSIDADE DE SÃO PAULO \\ FACULDADE DE FILOSOFIA, LETRAS E CIÊNCIAS HUMANAS \\ DEPARTAMENTO DE FILOSOFIA
}

\title{
RAZÃO E LIBERDADE EM LEIBNIZ
}

\author{
André Chagas Ferreira de Souza
}

Dissertação apresentada ao Programa de Pós-Graduação em Filosofia, na Faculdade de Filosofia, Letras e Ciências Humanas da Universidade de São Paulo, para obtenção do título de Mestre em Filosofia.

Orientador: Prof. Dr. Luiz Henrique Lopes dos Santos

São Paulo

2006 


\section{UNIVERSIDADE DE SÃO PAULO \\ FACULDADE DE FILOSOFIA, LETRAS E CIÊNCIAS HUMANAS \\ DEPARTAMENTO DE FILOSOFIA}

\section{RAZÃO E LIBERDADE EM LEIBNIZ}

André Chagas Ferreira de Souza 
Dedico este trabalho

à Dona Euzira, aos meus pais e aos meus amigos 


\section{AGRADECIMENTOS}

A realização desta dissertação tornoutse menos árdua a partir do apoio recebido de muitas pessoas que me acompanham há algum tempo. Em primeiro lugar, não poderia deixar de agradecer aos meus familiares, sobretudo à minha avó, Dna. Euzira.

Em seguida, gostaria de agradecer aos meus sempre amigos (extra-academia): Manso, César, André, Alex, Augusto; e também aos novos: Will, Flávio, Koich KK (e a todo o pessoal da "Caravana...").

Em relação ao meio acadêmico, queria dedicar este trabalho a toda nossa turma de 2000-2001, e a alguém do período anterior, mas que sempre será especial. Mas queria agradecer principalmente a duas pessoas que me foram mais próximas, meus amigos Renato dos Santos Belo e Alberto Moniz da Rocha Barros Neto, que sempre me foram de grande ajuda. E não poderia esquecer-me do meu mais novo parceiro de estudos, que inclusive trouxe fôlego novo para este trabalho: você Ricardo Cruz.

Ora, é óbvio que não poderia deixar de agradecer infinitamente aos Professores Carlos Alberto, que me apresentou a filosofia leibniziana e me orientou no período da graduação, ao Professor e meu grande amigo Enéias Forlin, que me ajudou a iniciar esta dissertação, ao Professor Franklin Leopoldo e Silva, que sempre esteve envolvido no meu trabalho direta ou indiretamente. Agradeço em especial ao Professor Luiz Henrique Lopes do Santos, pois permitiu a elaboração desta pesquisa com o seu expediente e paciência infinita, e com quem aprendi muito sobre a filosofia em geral

Não poderia deixar de agradecer à minha amiga Ana Amélia, que me auxiliou na evisão, e ao professor Flávio Néri, que me ajudou nos assuntos referentes à língua francesa.

Devo muito aos funcionários da nossa Secretaria: Marie e Cia., muito obrigado!

Este trabalho foi realizado com o financiamento da Fundação de Amparo à Pesquisa do Estado São Paulo (FAPESP). 


\title{
RESUMO
}

O principal objetivo desta pesquisa é analisar alguns das principais idéias envolvidas no labirinto da liberdade, um dos assuntos de grande destaque dentro da filosofia leibniziana. Por um lado, Leibniz sempre defendeu a máxima racionalidade de todos os fatos, o que acaba por indicar que todos estes estão absolutamente predeterminados. Por outro, ele procurou mostrar que todos os seres racionais são moralmente responsáveis pelos seus atos conforme suas vontades. Por meio de um grande esforço conceitual, Leibniz procurou conciliar a idéia de um destino, racionalmente delineável, junto à idéia de liberdade das ações dos seres racionais; ele não quis defender nem a pura necessidade e nem o puro acaso. O principal aliado nessa tarefa foi o Princípio de Razão Suficiente. Este princípio ganhou foi fortalecido a partir do desenvolvimento do conceito das infinitas substâncias completas (entelechia, substância individuais, mônadas), que foi elaborado gradualmente ao longo da sua vida filosófica. Uma reconstrução básica de algumas das principais teses da metafísica leibniziana permite observar como as criaturas (especialmente as racionais) passaram a ser consideras as legítimas responsáveis por suas ações, sem que o mundo representasse uma espécie de caos.

Palavras chaves: razão, substância, liberdade, necessidade, contingência.

\begin{abstract}
The main goal of this dissertation is to investigate some aspects of the Labyrinth of Freedom, a key subject in the Philosophy of Leibniz. On one hand, Leibniz supported the maximum rationality of all events, meaning that they are all absolutely predetermined. On the other, he tried to show that rational beings are morally responsible for their actions, and that requires free will. Through an act of great intellectual effort Leibniz tried to conciliate an idea of all embracing destiny (rationally understood) and the concept of freedom. He resisted admitting a vision of the world driven either by absolute necessity or lost to pure chance. His main ally in this task was the Principle of Sufficient Reason. This principle gained strength from the development of the concept of infinite substances (entelechia, individual substance, monades) that was gradually forged throughout the philosopher's life. A brief reconstruction of some of the main features of Leibniz's metaphysics allows us to perceive how all creatures (especially rational ones) could be seen to be truly responsible for what they do and the choices they make in a rationally structured world.
\end{abstract}

Key-words: reason, substance, freedom, necessity, contingency. 


\section{SYNTHÈSE}

Cette recherche a pour but d'analyser quelques idées sur le labyrinthe de la liberté, un sujet qui joue un rôle spécial dans la philosophie leibinizienne. D'une part, Leibniz a toujours défendu l'existence d'une raison pour tous les faits, et il a conclu qu'ils sont totalement determinés. D'autre part, il a essayé de montrer que tous les êtres raisonnables sont moralement résponsables, ce qui exige l'idée de liberté des ses actes et une vraie utilisation de leur volonté. Comment pourrait-on défendre deux thèses si distinctes en même temps, sans qu'il y ait une contradiction? Leibniz a soutenu l'existence d'un destin, totalement intelligible, et l'existence de la liberté des êtres raisonnables. Il n'a pas cogité l'existence de la pure necessité ni le pur hasard. Dans cette tâche, le Principe de Raison Suffisante a été un grand allié. Ce principe a été fortifié par le nouveau concept de substance (entelechia, substance individuelle, monade), qui a été developpé peu à peu das la vie philosophique de l'auteur. Une reconstruction des principales thèses metaphysiques leibniziennes sur ce labyrinthe permet de remarquer comment les créatures (les raisonnables en particulier) sont devenues les responsables légitimes sur leurs actes, sans que le monde exprime quelque sort de désordre.

Mots-clés : raison, substance, liberté, necessité, contingence. 


\section{ÍNDICE}

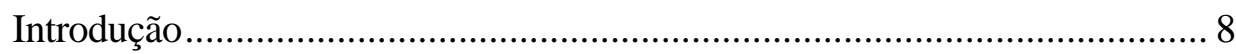

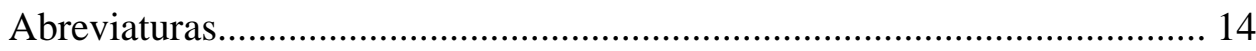

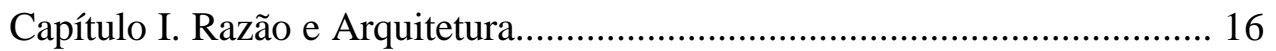

1.1. O Princípio de Razão e o Jogo dos Requisitos......................... 16

1.2. Verdade, Substância e Ação................................................... 32

Capítulo II. O Problema da Contingência...................................................... 54

Capítulo III. Necessidade Moral e Liberdade................................................. 78

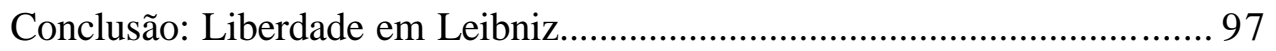

Referências Bibliográficas................................................................... 100 


\section{INTRODUÇÃO}

"O mais incompreensível do mundo é que ele seja
compreensível" (A. Einstein).

Livre arbítrio e destino são duas idéias que dificilmente são tratadas em conjunto ma ótica do senso comum. É óbvio que as opiniões do dia-a-dia não devem ser menosprezadas, mas quando se trata de olhar as coisas mais a fundo, é possível elaborar um discurso que vai de encontro às crenças quotidianas. Isso é perceptível no caso dos dois, de agora em diante, conceitos que abrem este texto. Outro detalhe chama atenção, pois muitos dos mais competentes pensadores corroboraram aquela opinião: se tudo está predeterminado, não há liberdade, mas apenas domínio da pura necessidade. Outros defenderam a liberdade, apesar de distanciá-la de qualquer idéia de predestinação. Assim, torna-se visível a dimensão do grande desafio tomado por Leibniz para provar que liberdade e predeterminação não são idéias auto-excludentes. Ele se viu na situação de enfrentar tanto os fatalistas, defensores da necessidade absoluta de todos os eventos, quanto os partidários da liberdade irrestrita.

Minha proposta é realizar uma reconstrução da estratégia leibniziana de dissolução do labirinto da liberdade. Esse tema perpassa boa parte dos seus escritos direta ou indiretamente, tendo sido tratado em momentos distintos e de maneiras diversas. Mas antes é preciso indicar algumas das primeiras dificuldades para todo aquele que se propõe a tratar tal assunto. Em primeiro lugar, há um problema de ordem prática - reconhecido por praticamente todos os estudiosos: a falta de um corpus leibniziano, ao contrário do que ocorre com outros autores. Em relação à extensão da sua obra, há pouquíssimo material, por assim dizer, bem acabado. Há uma infinidade de opúsculos e rascunhos que, além da grande quantidade, são difíceis de serem analisados, visto que não eram destinados ao grande público. É certo que existem vários textos centrais que suprem as principais necessidades acerca do tratamento das principais questões de Leibniz. Entretanto, 
dificilmente alguém alcança sucesso nesta tarefa sem passar por alguns dos opúsculos "mais obscuros" ou mesmo por parte da extensa correspondência deste autor.

Fora esse problema de ordem prática, que não deixa de influenciar o próximo, para todo aquele que passa rapidamente os olhos sobre os escritos desse autor, existe a impressão de uma uniformidade nas suas teses desde os primeiros trabalhos. No entanto, como virá abaixo, uma leitura mais detalhada revela a ocorrência de variações das mais consideráveis. Daí as dificuldades em sustentar a idéia de um único sistema leibniziano, apesar de muitos conceitos já se apresentarem de maneira intuitiva desde a fase seminal do seu pensamento.

Sem dúvida, a palavra liberdade é um termo que merece ter o seu sentido delimitado, e o próprio autor pode ajudar neste caso. Nos Novos Ensaios (II 21 8), ele reconhece que a palavra liberdade tem um sentido ambíguo. Não me deterei em todos os aspectos, pois não é o meu propósito esgotar a todos (se é que seja possível esgotar algum deles). Um dos sentidos refere-se à liberdade de fazer, aquela liberdade em que todos estão acostumados no dia-a-dia, principalmente quando se refere às ações do corpo. Neste caso, um prisioneiro, p. ex., não pode ser considerado livre. Há um segundo sentido, que se liga à liberdade da vontade, a qual pode ser dividida em duas modalidades: liberdade do espírito e livre arbítrio. Segundo Leibniz, a primeira é defendida pelos estóicos. Para tornar-se livre, dizem eles, basta eliminar as paixões da alma, mas sem que o espírito delibere sobre algo, pois como é sabido, para o estóico, tudo é absolutamente necessário, e qualquer impressão de contingência ou acaso não passam de uma ignorância do sujeito. Apenas uso do entendimento permitiria a liberdade, pois ele seria o remédio para as paixões; assim, apenas o sábio poderia ser livre.

Leibniz interessourse mais pelo outro sentido da liberdade da vontade, o livre arbítrio, que:

“...consiste no fato de querermos que as razões ou impressões mais fortes que o entendimento apresenta à vontade não impeçam o ato da vontade de ser contingente $\mathrm{e}$ não dêem uma necessidade absoluta e, por assim dizer, metafísica. É neste sentido que costumo dizer que o entendimento pode determinar a vontade, segundo a prevalência das percepções e razões, de uma forma que, mesmo quando é certa e infalível, inclina sem obrigar." 
Esta passagem sintetiza o sentido de liberdade e o foco do que será visto doravante, sobretudo no que se refere à distinção entre vontade e entendimento, e de como ocorre a relação entre ambos. Feitas essas pequenas ressalvas, é possível passar para a apresentação geral do que virá a seguir.

Basicamente, para Leibniz, a definição geral de liberdade é composta de três ingredientes, cujas denominações podem sofrer variações: inteligência, espontaneidade $e$ contingência. Essas idéias estão muito próximas daquilo que, no pensamento aristotélico, é conhecido como escolha deliberada. Uma ação é considerada livre caso o agente reconheça e almeje um objeto. Em seguida, ele deve agir por si, i. é, ele próprio deve ser sua fonte de ação. E, em último lugar, ele deve ter a capacidade de escolher entre opções contrárias, igualmente possíveis, ou mesmo deve poder interromper o seu ato. Essa definição de liberdade deve valer tanto para o criador, como para os seres racionais, visto que são os que mais se aproximam de Deus. Isso oferece o panorama do que deve ser tratado.

Antes de entrar em cada ponto da liberdade, foi notada a necessidade de entender a outra face do problema: o que Leibniz entende pela determinação (certeza, previsão, necessidade moral etc.), que tem como principal foco o princípio de razão suficiente (PRS)? "Nada é sem razão" é a grande máxima que perpassa toda sua obra e de onde aqueles ingredientes são derivados. O PRS - sem deixar de lado o princípio de não contradição (PNC) - é fundamental para a constituição de tudo aquilo que existe. Como há diversas coisas que não apresentam uma razão suficiente para existir no seu próprio conceito, é preciso retroceder até o ponto em que o princípio ganha sustentação, que pode ser apenas algum ente de existência necessária: Deus. O PRS oferece as regras do que pode ser chamado de arquitetura do mundo, as quais apenas Deus pode operar.

Entretanto, o grau de importância do PRS é proporcional à complexidade que ele envolve. Conforme o aviso anterior, não se pode dizer que ele tem sempre a mesma fisionomia nos vários momentos em que é invocado pelo autor. A partir desse ponto, a minha proposta será seguir um roteiro que o próprio Leibniz oferece no De Libertate. Num primeiro momento, ele mesmo reconheceu que estava muito próximo do pensamento espinosista. No meu entender, este problema o assolava quando ele pensava a arquitetura 
apenas em termos de elementos simples (elementae simplices), sem que a vontade divina tivesse participação efetiva na própria criação das coisas. Todo existente era visto como resultado da reunião dos elementos simples, os atributos positivos, o mesmo valendo para ações. Se ocorresse a união (suficiente) dos requisitos, contanto que nada impedisse este processo, tudo levava a crer na ocorrência (necessária) das ações. Assim como no espinosismo bastava que algo aparecesse na mente divina para ser efetivado; quando se tratava do estado mais harmônico, tudo indicava que este já seria conduzido à sua eleição. Segundo Leibniz, para Espinosa, a "possibilidade" de algo já significava a existência; Deus, como ser absoluto, não precisaria ponderar entre alternativas (a idéia de vontade em Deus pressuporia a imperfeição deste), pois como imanente ao mundo, tudo não passaria de um processo interno ao mesmo. Devido às insuficiências metafísicas do seu sistema e da sua intenção de manter uma conduta moral que fosse adequada ao criador, Leibniz aproximouse do abismo necessitarista (espinosista). Não era difícil comprovar algo desastroso, pois como esse mecanismo era imputado apenas ao criador, Deus era visto como o único responsável por todos os atos, inclusive pelos maus, ou seja, Ele tornava-se o único pecador. O PRS gerava grandes problemas. Tudo indicava que a contingência também estava descartada em tal sistema.

É fato que a fase que este trabalho toma de início equivale àquela em que Leibniz afirma ter incorporado os possíveis. Ele pensa ter sido salvo do abismo espinosista por ter assumido a contingência dos fatos, em função dos possíveis não realizados. Não obstante, isso também não oferecia a saída final para tal problema, visto que ele ainda estava preso à região dos primitivae simplices ou das puras essências. Tudo indica que o grande salto se dá na reformulação do arcabouço ontológico, e o primeiro passo para esta mudança é dado a partir de uma nova idéia geral de verdade: o predicado contido na noção do sujeito de toda proposição verdadeira, ou princípio de in-esse. A noção geral da verdade é o que prepara a nova idéia de substância, a começar pela substância individual. Todo o ser passa a ser definido em termos de completude de sua noção, seja existente, seja possível. Esta tese ocasiona várias implicações, a saber: a unidade, a compossibilidade, a máxima distinção entre os seres, a perenidade e a própria espontaneidade. Tudo isto oferece o novo tom da arquitetura elaborada pelo criador. A partir daí, Leibniz busca assegurar a ação das criaturas e uma verdadeira idéia de vontade em Deus, apesar das 
outras dificuldades que surgem em tal pensamento; basta ver as discussões do autor com um dos seus principais interlocutores, Arnauld.

Aparentemente, o princípio de in-esse não assegurava a contingência dos fatos, pois como toda criatura passou a ter uma natureza composta pela totalidade dos seus predicados, algo comprovado a priori, é difícil aceitar a possibilidade de algo ser feito diferentemente do que está programado na noção completa. Provavelmente, este é o centro do nó a ser desfeito. As dificuldades são menores quando se trata de associar a nova face do PRS à inteligência e à espontaneidade; o mesmo não se pode dizer no caso da contingência. Como garantir a não necessidade dos fatos sem prejudicar a máxima inteligibilidade do conceito de todos os seres? É visível a dificuldade em querer manter as verdades de fato, quando todo predicado é intrínseco a alguma noção, pois a contingência exige uma maleabilidade na atribuição de uma parte dos predicados ao conceito. Caso tal conciliação seja comprovada (PRS e contingência), será possível fazer a passagem da dimensão da arquitetura para o reino da moralidade.

Mesmo que aqui se fale em arquitetura divina e em reino divino, não é necessário separá-los em absoluto. Quando se trata da armação do mundo, é importante ver como operam os atributos divinos: a onisciência, a onipotência e a bondade. Leibniz entende que a construção do mundo foi orientada por aquilo que foi reconhecido como o ótimo, mas sem que o criador fosse forçado a se dirigir para tal alternativa, a não ser pela própria natureza daquele. Antes de tudo, ele quer o objeto melhor acabado, que foi previamente identificado dentre diversas possibilidades de criação, as quais foram descartadas por não alcançarem o máximo, como no caso da opção escolhida. Como ele é dotado de máximo poder - nada pode impedilo - ele não deixa de realizar sua melhor obra. Todo o processo da construção metafísica é importante não apenas para resolver os problemas que Leibniz se deparou a partir das suas antigas bases ontológicas, como também para alcançar o paradigma da liberdade.

Da mesma forma que o criador age em função do verdadeiro bem, neste caso o melhor, todo ser se dirige ao seu próprio objeto, o que lhes parece um bem. Entretanto, apenas os seres dotados de razão (apercepção) podem imitar o seu criador, a despeito das imperfeições que os envolvem. Apenas o criador persegue o verdadeiro bem, ao passo que todas as criaturas procuram o que lhes parece ser um bem. Assim como Deus pondera entre 
várias alternativas de criação, até alcançar o que lhe parece digno de escolha, os homens também perseguem aquilo que lhes é mais favorável; isto é previsto pelo criador. Eles não apenas agem por si, mas deliberam sobre o objeto almejado. Ao contrário de Deus, eles estão presos aos sentidos (simples aparências), os quais podem servir de empecilho no momento de reconhecer o que seria um bem mais adequado para a ação. Sem entrar em todos os detalhes envolvidos aqui, é importante notar que não existe ação sem motivo ou sem que haja reconhecimento de um bem, mesmo que em aparência; a vontade é inútil sem a presença de qualquer coisa que atraia sua atenção.

Deus opera a partir do seu máximo intelecto e identifica o que é o melhor, sem que nada interfira na sua escolha final. Apesar dos defeitos (essenciais) das criaturas, de alguma maneira, parece que sempre haverá algum grau de liberdade nas ações humanas. No desenrolar dessa dissertação, será possível notar que mesmo o sentido de liberdade não se limita a apenas um.

Leibniz também entendeu que o fato dos atos dos homens serem predeterminados deve afligi-los menos do que possam imaginar, pois as criaturas não deixam de contribuir positivamente com a construção dos seus destinos. 


\begin{abstract}
ABREVIATURAS*
A - Sämtliche Schriften und Briefe, hrsg. von der Preussischen, bzw. der Deutschen Akademie der Wissenschaften zu Berlin. (citado na seguinte seqüência: série, tombo e página).

C - Opuscules et fragments inédits de Leibniz, org. par L. Couturat.

Conf. - Confessio Philosophi - La profession de foi du Philosophe, ed. e trad. por Y. Beleval

DM - Discurso de Metafísica (in A VI 4B, citado por artigo; tradução a partir da edição: Leibniz, G.W., Discurso de Metafísica e outros escritos).

DSR - De Summa Rerum, Metaphysical Papers 1675-1676 (citado por página; versão original in A VI iii; alguns opúsculos trad. in Rech. 9-37).

FC - F. de Careil: Lettres et opuscules inédits de Leibniz, précédées d'une introduction par A. Foucher de Careil. Paris, 1854.

GP -Die Philosphischen Schriften von Gottfried Wilhem Leibniz (citado por volume e página).

Gr - Textes inédits : d'après les manuscrits de la Bibliothèque provinciale de Hanovre, publiés et annotés par Gaston Grua.

L - Philosophical papers and letters, ed. Leroy E. Loemker.

Mon. - Monadologia (in: GP VI, citado por parágrafo, tradução a partir da edição de Discurso de Metafísica e outros escritos).

LP - Leibniz - Coleção Os Pensadores (1978)

NE - Novos Enasios acerca do Entendimento Humano (in: GP V, citado por livro, capítulo e parágrafo; me valerei exclusivamente do II, 21 ; tradução a partir de Leibniz -1999).

O - Escritos Filososficos, edición de Ezequiel de Olaso.

Rech. - Recherches générales sur l'analyse des notions et des vérités 24 thèses métaphysiques.
\end{abstract}

\footnotetext{
* As citações serão acompanhadas, em primeiro lugar, pelas referências das edições padrões e, após a barra, pela referência de uma outra edição ou tradução.
} 
Th - Essais de Théodicée ( in: GP VI, citado por parágrafo; apêndices: Thr Resumo da Controvérsia; Thk - Comentário sobre um livro que trata a origem do mal..., The - La causa de Dieu). 


\section{RAZÃO E ARQUITETURA}

\section{1. O PRINCÍPIO DE RAZÃO E O JOGO DOS REQUISTOS}

O Princípio de Razão Suficiente (doravante: PRS) é invocado ao longo de praticamente toda a obra leibniziana. Simplesmente, segundo o pensamento de Leibniz, ele é base da própria constituição de tudo o que existe e para a própria inteligibilidade das coisas do mundo. Os anos de Paris (1670-1676) podem ser úteis para iniciar o contato com o PRS, pois apresentam escritos determinantes para a filosofia de Leibniz. Nesse período, ele pôde ter contato com figuras importantes da época, pondo fim à sua sensação de isolamento naquela Alemanha ainda tão longe da ilustração. Paris também propiciou um melhor contato de Leibniz com a obra cartesiana, o que foi fundamental para o desenvolvimento do seu pensamento, seja pela influência direta desta, seja pelas objeções dirigidas ao ilustre pensador francês.

Sua grande tarefa foi claramente demarcada em terras francesas, ou melhor, em Paris iniciourse um processo que resultaria na fase madura da filosofia leibniziana. Mesmo sem possuir um papel predominante ${ }^{1}$, sua metafísica foi contemplada com escritos preciosos neste período (incluindo correspondências; grande parte da A II), dentre os quais dois merecem destaque. O primeiro deles é uma seleção de opúsculos conhecida como $D e$ Summa Rerum ${ }^{2}$. Essa série de textos se caracteriza por apresentar um grande projeto de Leibniz, principalmente por envolver questões de conhecimento e método, que pode ser sintetizado pelos três programas: a enciclopédia, a ciência geral e a característica ${ }^{3}$. A

\footnotetext{
${ }^{1}$ Um aspecto que merece destaque é o fato de ter sido um período em que Leibniz teve grande preocupação com as disciplinas exatas. Foi em Paris que as idéias do cálculo e as novas leis da dinâmica apresentaram-se com grande força, abrindo o caminho para o que viria a ser o seu tão conhecido "sistema metafísico". Mercer, in Jolley (1995), p.84.

2 A VI iii/ DSR/ Rech. 9-37.

3 "In writings from his early Hanover years, Leibniz formulates his scheme for universal knowledge in terms of the three projects (...): the encyclopedia, which would serve as a repository for all acquired knowledge and would include a complete catalogue of the most basic concepts and principles; the general science, which would supply a method for arranging and relating the contents of the encyclopedia according to a strict logical order; and, closely associated with the general science, the universal
} 
outra obra metafísica que merece destaque é a Confessio Philosophi. Em poucas páginas deste diálogo, Leibniz consegue não apenas apresentar os elementos exclusivos do período de Paris, mas também uma infinidade de questões que foram moeda corrente no seu pensamento futuro, principalmente as relacionadas ao território teológico-moral. A parte inicial deste capítulo se deterá principalmente nestes textos, já que apresentam alguns pontos limites que esse autor deveria aprimorar ${ }^{4}$.

$\mathrm{Na}$ Confessio, as velhas questões da justiça divina e a autoria do mal abrem o diálogo entre o Teólogo e o Filósofo. Como Deus poderia estar na origem do mal? Essa objeção merece ser observada mais a fundo. A onisciência e a onipotência são perfeições associadas diretamente a Deus que, por portá-las de maneira exclusiva, se apresenta como o próprio fundamento de todas as criaturas presentes no mundo. Logo, é permitido afirmar (não ainda de maneira conclusiva) que Deus é o único ser que existe com absoluta necessidade, visto que no processo regressivo de busca pelas causas, ou razão, apenas ele se apresenta como senhor de uma realidade em si, independente de qualquer outro ser. Tudo o que faz parte deste mundo encontra-se na sua mente, enquanto possuidora de máxima ciência, e existe porque o ser necessário tem o poder de criar aquilo que é apresentado pelo seu intelecto, o que já não é tão óbvio. O fundamento da existência (e das essências) não se encontra nas coisas mesmas, mas está numa fonte externa (A VI iii 514/ DSR 69).

Neste ponto as dificuldades começam a aparecer. Como não pensar que tal ser seja, indistintamente, responsável pelas coisas boas deste mundo, como também pelas más. Isso resume drasticamente o problema que a teodicéia busca resolver (termo cunhado pelo próprio Leibniz). Todavia, essa questão tem uma armação peculiar na Confessio. Antes de tudo, o texto começa com a idéia de Harmonia, que significa a identidade no interior do mundo aparentemente caótico (Conf. 30/31). Tudo é abarcado pela máxima harmonia, i. é, nenhuma ação ou qualidade presentes no mundo foge a esse conceito.

Deus e harmonia refletem um ao outro. Como isso se dá? Ora, para Leibniz, a harmonia envolve o mundo na medida em que este é assimilado pela própria ciência divina.

characteristic, which would supply it with appropriate symbols, such that all the reasoning associated with the encyclopedia could be transformed into purely formal deductions, thereby ruling out the possibility of error" (Rutheford, p.101). Estes primeiros anos de Hanover são precedidos exatamente pelos anos de Paris. A partir do seu método, Leibniz quis tornar a metafísica uma ciência demonstrativa, a começar pelos fundamentos desta (o que havia de elementar no pensamento) para, então, alcançar as verdades mais complexas ( síntese). A inspiração se dava, sobre tudo, a partir da sua ars combinatória.

${ }^{4}$ Parkinson, in DSR, pp. XIII-XIV. 
Tudo se mostra ao intelecto perfeito. Eis a grande máxima leibniziana aparece de imediato: 'Rien n'a lieu sans raison' (Conf. 13435). Não há nada ininteligível ou que não tenha uma causa. Entretanto, mesmo que a fisionomia do princípio seja semelhante à encontrada no restante dos textos desse autor, ela não deixa de apresentar as peculiaridades dos anos parisienses. Tudo tem uma razão, pois:

«Celui qui nie cela (qu'il y a une raison) détruit la distinction entre l'être lui-même et le non-être. La chose, quelle quelle soit, qui existe, aura assurément tous les réquisits pour exister ; or, tous les réquisits pour exister pris ensemble sont la raison suffisante d'exister; donc tout ce qui existe a une raison suffisante d'exister » (Conf. 34/35 ; grifo meu).

Aqui, o PRS é associado à noção de requisito, que exige uma análise de outros textos (DSR) para ser entendido. Além de oferecer alguma luz aos problemas envolvidos na Confessio, os outros trabalhos deste período deixam ainda mais claro o que Leibniz pensa acerca do PRS na sua estrutura elementar.

A noção de requisito é um assunto bastante delicado; o pensamento de Leibniz estava principalmente sob o domínio da ars combinatoria ${ }^{5}$. Contudo, o importante é notar o momento em que o autor afirma que a combinação suficiente de requisitos primitivae simplices) fundamenta a razão de algo; a falta de qualquer um deles impossibilita qualquer existência ${ }^{6}$. Requisito é idêntico ao conceito de razão ou à própria razão suficiente ${ }^{7}$; ele é a própria razão mínima daquilo que existe. Algo pode ser efetivado somente com a união das suas notas. Eles fundamentam tudo o que pode aparecer no mundo. Quanto maior o índice de essência, mais a coisa tende a existir (A VI iii 491/ Rech. 21) . $^{8}$.

Outro detalhe que deve ser ressaltado é o fato dos requisitos não possuírem sua fonte na própria criatura, enquanto existente ou enquanto possível. Há um único suporte para todos eles.

\footnotetext{
${ }^{5}$ Fichant (1998), p.86. Não me deterei nos aspectos de ordem técnica deste assunto. Para uma visão geral ver Kneale, Cap. V, 2-3. O importante será notar que os requisitos são inspirados pela lógica atomista (primitivae simplices)/combinatória de Leibniz. Mas a passagem da concepção lógica para a metafísica não está livre de problemas.

${ }^{6}$ Parkinson, p. xxiii, in DSR.

7 Ibidem.

${ }^{8}$ É a primeira maneira como Leibniz pensou o critério para a distinção entre os possíveis, o que abriu o espaço de disputa entre eles.
} 
«Il est nécessaire pour l'exister que soit présent l'agrégat de tous les réquisits. Un réquisit est ce sans quoi la chose ne peut pas être. L'agrégat de tous le réquisits est la cause pleine de la chose. Rien n'est sans raison. Car rien n'est sans l'agrégat de touts les réquisits. Dans les corps il n'y a pas de raison d'existir. On le montrerait facilement : même si, en effet, on devait régresser à l'infini, on ne ferait que multiplier les corps, on ne comprendrait pas la raison pour laquelle il en est ainsi pluôt qu'autrement. Pour corps quelconque donné, l'agrégat de tous se réquisits est en dehors des corps. L'agrégat de tous les réquisits d'un corps et l'agrégat de tous les réquisits d'un autre corps sont dans un seul et même Être. Cet Être unique, quel qu'il soit, est la raison ultime des choses.(...)L'Être necessaire contient en soi les réquisits de toutes choses » (A VI iii 587/ Rech. 30 - grifo meu).

Esta longa passagem sintetiza de modo extraordinário a noção de requisito e mostra a presença de apenas uma origem para todos eles. Isso demonstra o principal modo como Leibniz procurou assegurar um lugar para a figura divina nesta época. Deus seria a sede, ou sujeito, de todos os elementos que entrariam na composição do mundo e das coisas possíveis. Sua existência seria consequiência direta ou idêntica à sua essência. Isso foi apenas para apresentar uma visão geral do assunto. O importante é ver no que resulta esse primeiro sistema combinatório, o jogo dos requisitos.

É válido lembrar a preocupação de Leibniz em sustentar que tudo seria fundamentado, essencialmente, a partir de certos elementos, tanto as coisas existentes quanto "as possíveis", ou seja, o mundo seria uma coleção de partes elementares indecomponíveis, que se expressariam de diversas maneiras. Mesmo que na maioria das vezes os pensamentos e as percepções humanas não consigam detectá-los diretamente, Leibniz afirmou que eles devem ser pressupostos. Apenas Deus pode abarcar e detectar todos esses elementos, além de igualar-se essencialmente à totalidade dos mesmos. Ele é idêntico à totalidade de todos os requisitos. Tudo depende da associação de partículas elementares, o que deve ser entendido da maneira mais geral possível ${ }^{9}$.

\footnotetext{
9 A noção de requisito pode ser associada ao que chamo de elementos (atributos positivos, notas ou perfeições). Através de um processo regressivo, os requisitos apresentariam várias pistas. No pensamento, $\mathrm{p}$. ex, o ponto final estaria nas proposições idênticas, ou indemonstráveis, que são suficientes no que diz respeito ao campo do intelecto; elas podem ser reduzidas a elementos mais básicos do pensar, mas isso já estaria muito além dos limites do que é cognoscível para as criaturas (A VI iii 504-505/ Rech. 21-22; cf. O 190ss). Na percepção, também é de se supor a presença dos elementos simples, mas eles se perdem na massa perceptiva, que vê tudo como um grande oceano (Fichant - 1998, p.85).

«La raison est la somme des réquisits. Les sensibles ne peuvent être parfaitement compris par nous parce qu'une infinité de choses concourent à leur constitution, du fait de la divisibilité à l'infini du temps et de l'espace. Il suit que la perception d'une qualité sensible n'est pas une perception mais
} 
Após essa apresentação brusca da noção dos elementae simplices, é importante entender um pouco das noções de possibilidade e impossibilidade para Leibniz neste período. A idéia de impossibilidade pode ser desdobrada em dois casos (A VI iii 464-465/ Rech. 19). No primeiro deles quando algo é essencialmente impossível. O caso de contradição expressa ilustra o que seriam estes impossíveis. São situações completamente inconcebíveis, visto que portam uma contradição absolutamente essencial, como "1 + 2 diferente de 3". Pode-se falar no maior de todos os números, mas isso não será verdadeiro de maneira alguma (A VI iii 462/ DSR 3), pois mesmo o suposto maior dentre eles, p. ex., pode ser elevado ao quadrado e, assim, seria o mesmo que considerar a parte (uma fração da série) maior que o todo (a própria série), o que não tem nenhum cabimento. Este caso de incompatibilidade fundamentará o conceito de impossibilidade absoluta, que se opõe ao absolutamente necessário ${ }^{10}$.

A outra maneira de identificar impossibilidade ocorre quando algo se encontra fora da existência. Isso está diretamente relacionado com as idéias de compatibilidade e de incompatibilidade dos atributos positivos. Aquilo que foi contemplado com a existência tem esse privilégio por ser mais harmônico, ou seja, existe porque contribui para a beleza daquilo que é criado ${ }^{11}$. Aquilo que não é atualizado pode deixar existir não propriamente pelo fato de ter um conceito auto-contraditório, mas exatamente porque não apresenta um nível de compatibilidade que o habilite a vir para este mundo, o mais rico em compatíveis $^{12}$. Logo, se não é compatível com o que foi realizado, isso significa que não

l'agrégat d'une infinité de perceptions » («Sur les formes ou atributs de Dieu», in Rech 26, grifo meu).

Isso já envolve algumas questões acerca do conhecimento e das idéias (e até das percepções não apercebidas), pois é possível compreender algo em vários níveis a partir do grau de clareza "perceptiva" dos elementos que entram na composição de algo ("Meditaions sobre el conocimento..." in O 271s; DM XXIV). Como poderá ser visto, a noção de vontade também será entendida em termos de soma de requisitos (face psico-moral, por assim dizer), pois a ocorrência de tudo depende da somatória mínima de elementos positivos (cf. ambos textos de Gueroult - 1970: "La constitution de la substance chez Leibniz" e "Substance and the primitive simple notion in the philosophy of Leibniz") .

10 "Carta de Leibniz a Malebranche", 22 de junho de 1679 (G I 33); c.f. A VI iii 462/ DSR 3.

11 Este segundo caso é o mais importante para entender os futuros conceitos de compossibilidade e incompossibilidade.

${ }^{12}$ Esta passagem resume parte dessas duas espécies de impossibilidade:

« La notion de l'impossible est double : ce qui n'a pas essence et ce qui n'a pas d'existence, c'est-àdire qui n'a pas été, n'est pas et ne sera pas, ce qui est incompatible avec Dieu, ou avec l'existence, ou avec la raison qui fait que les choses sont plutôt qu'elles ne sont pas. Il faut voir si l'on peut démontrer qu'il y a des essences auxquelles manque l'existence. Afin que l'on ne dise pas que l'on ne peut rien concevoir qui ne doive être à un moment quelconque dans toute l'eternité. Tout ce qui est, sera et a été constitue un tout. Ce qui est incompatible avec le nécessaire est impossible. Raison qui fait que ceci est 
combina com o estado mais harmônico, ou seja, é algo com baixo nível de essência. Deus é absolutamente perfeito e sede de todos (os requisitos e de todos) os possíveis. O mundo é fruto da harmonia dos seus elementos, e essa arquitetura é originada no próprio entendimento de Deus, que identifica a melhor circunscrição em meio aos atributos positivos. Se algo não se encaixa no melhor dos planos, será recusado pelo grande artesão, mesmo que não seja absolutamente impossível; o que não existe não apresenta o mais alto grau de essência.

«Or mon principe est que toute chose qui peut exister et qui est compatible avec les autres existe, parce que la raison pour laquelle existent tous les possibles ne doit être limitée par aucune autre raison, si ce n'est qu'ils ne sont pas compatibles(...)» (A VI iii 582/ Rech. 29) ${ }^{13}$.

No "Diálogo entre Teófilo e Poliandro" (Gr 258-257 - que é datado por Grua como do final de 1670), Leibniz ilustra bem a idéia de compatibilidade e incompatibilidade e da riqueza de essência. As questões da necessidade e da razão da existência orientam a discussão entre as duas personagens. Poliandro, no início, tende a entender que a existência deste mundo é necessária, pois ele tem uma posição semelhante à dos estóicos; ele defende uma anima mundi ${ }^{14}$, donde tudo é fruto operação interna desta. Teófilo, por outro lado, quer mostrar que se fosse desta forma, não haveria uma verdadeira razão para o existente, ou seja, não haveria uma maneira de mostrar porque as coisas são assim e não de outra forma (uma idéia chave para a manutenção da moralidade de qualquer ação). Teófilo procura assegurar um critério para a existência de certas coisas em detrimento de outras ${ }^{15}$, e isso seria fundamentado no conceito da riqueza de essência, o que combinaria com o ser perfeito. Então, ele exemp lifica isso da seguinte forma $(\mathrm{Gr} 285-286)^{16}$ : se fossem tomados os elementos possíveis A B C D E F G, igualmente perfeitos e passíveis de existir, dentre os quais fossem incompatíveis os seguintes elementos: A com B, B com D, D com G, G com C, C com F e F com E, seria possível formar: quinze conjuntos compostos de dois elementos (AC, AD, AE, AF, AG, BC, BE, BF, BG, CD, CE, DE, DF, EG, FG), nove

plutôt qu'autre chose. Double origine de l'impossibilité ; l'une à partir de l'essence, l'autre à partir de l'existence ou position» (A VI iii 463-464 / Rech. 18).

${ }^{13}$ Cf. A VI iii 587-588/Rech 30.

${ }^{14}$ Como será visto, nos anos parisienses, o próprio Leibniz não esteve tão longe da opinião de Poliandro.

${ }_{15}^{15}$ Logo, ele também procura assegurar os possíveis, mas isso ainda não é o ponto.

${ }^{16}$ Cf. Fichant (1998), p. 89. 
conjuntos de três elementos (ACD, ACE, ADE, ADF, AEG, AFG, BCE, BEG, BFG) e, finalmente, um conjunto de quatro elementos (ACDE). Teófilo, então, conclui que o conjunto ACDE:

“(...) será escolhido entre todos os outros, pois a partir deste obtém-se o melhor que se pode; por conseguinte, os quatro elementos ACDE serão preferidos em detrimento de BFG, que serão excluídos, pois não poderiam formar um conjunto com quatro elementos" (Gr 286).

O ser onisciente reconhece a melhor combinação de tudo o que forma o mais belo mundo, ou seja, a mente divina reconhece a melhor armação de todos os atributos positivos. O critério para a formulação e, em seguida, para a própria criação é a simplicidade associada ao resultado geral. Da mesma maneira que a esfera é o sólido de maior capacidade, a composição mais simples e superior em efeitos é o alvo imediato de Deus; logo, existir será: “ ser concebido por Deus como o melhor, isto é, como o mais harmônico" ${ }^{17}$. Em linhas gerais, mesmo com alguns problemas em aberto, era assim que Leibniz entendia o fundamento da organização do mundo. Em primeiro lugar, os atributos positivos deviam engendrar uma essência que fosse consistente, ou seja, que não fosse autocontraditória. Em seguida, a melhor junção dos requisitos, a mais harmônica, cuja identificação fosse puramente intelectual, seria o objeto direto da criação divina. Por outro lado, a própria existência de tal mundo comprovava a presença do ser onisciente e onipotente, o que propiciava também uma prova (mais consistente) da existência de Deus, sede intelectual dos requisitos ${ }^{18}$ e o responsável pela melhor associação dos mesmos, que viriam a existir em função dele. Um mundo como esse podia ser apenas uma criação divina.

Se o critério de compatibilidade já cria limites para as coisas que podem existir, ele é um argumento ainda mais forte contra os que afirmavam que todo o possível seria contemplado com o decreto. Já que a totalidade dos possíveis não é totalmente compatível entre si no plano real - apenas na composição da essência do criador -, nem todos eles podem vir a existir (FC 178-179). Se existisse tudo o que é possível, não haveria motivo para afirmar a idéia de uma máxima razão, pois tudo surgiria automaticamente.

\footnotetext{
17 Ibidem, idem.

${ }^{18}$ Mercer, op. cit., p.85.
} 
«Si tous les possibles existaient, il n'y aurait pas besoin d'une raison d'existence, et la seule possibilité suffirait. Et dans ce cas même Dieu ne serait qu'en tant qu'il est possible. Mais un Dieu comme celui auquel croient les personnes ne serait pas possibles, si l'opinion de ceux qui pensent que tous les possibles existent était vraie» (A VI iii 582/ Rech. 29 - grifo meu).

Não é porque A e B são possíveis individualmente que eles existem automaticamente, pois se ambos forem incompatíveis, eles não poderão existir simultaneamente. Deus se vale dessa regra. A totalidade do espaço de possibilidades não é absolutamente realizável.

É preciso acrescentar que se faltasse algum critério de distinção essencial entre A e B, seria indiferente escolher entre ambos, o que também seria inconsistente com qualquer princípio racional-moral que entrasse no mundo, pois se as possibilidades são essencialmente idênticas ou portadoras dos mesmos requisitos, não há critério de valor e não há o que escolher ${ }^{19}$. Assim, no caso de Deus, também não haveria motivo para louválo, já que a identidade dos objetos não permitiria uma eleição. Não ocorreria a guerra dos possíveis, e qualquer coisa escolhida daria no mesmo. Uma igualdade absoluta entre essências caracterizaria uma situação de indiferença entre as alternativas. Por sorte, ao contrário disso, a razão criadora se depara com diferentes situações possíveis, distintamente constituídas, o que permite a aplicação de juízos de valor sobre as diferentes opções, pois são moldadas de diversas maneiras ${ }^{20}$.

Todos esses detalhes (metafísicos) são considerados importantes já em vista de uma adequação moral da figura divina. A compatibilidade-incompatibilidade e a máxima discernibilidade estão no pano de fundo (framework) do caráter louvável de Deus. Leibniz procurava mostrar, há um bom tempo, que a criação não foi realizada de uma maneira indiferente. Há critérios envolvidos nesse mecanismo que permitem a formação de diferentes níveis de essência, que entram na formação de uma escala moral para as diferentes possibilidades de criação. Deve haver diferentes valores intrínsecos às alternativas.

\footnotetext{
19 "Existem graus de vontade, pois queremos mais uma coisa que outra. E queremos mais o que parece melhor, pois quanto maior a semelhança entre as coisas, tanto menos preferimos uma à outra, em suma, acabamos por não querer nada" ("Conversación con el Obispo Stenon acerca de libertad”, in Escritos em torno..., pp. 178-179). Isso reforça a importância da tese sobre a máxima distinção das coisas.

${ }^{20}$ Lopes dos Santos (1998), pp.98-99.
} 
«Rien n'est aussi inepte que d'imaginer qu'il n'y aurait dans le monde non seulement aucun monstre, mais encore aucune âme mauvaise et misérable, pas non plus d'injustice, et qu'il n'y aurait aucune raison pour laquelle Dieu pourrait être dit bon plutôt que méchant, juste plutôt qu'injuste. Il y aurait un monde dans lequel tous les honnêtes gens seraient punies de châtiments éternels et tous les malhonnêtes seraient récompensés ou expieraient le crime par la felicité »(A VI iii 581/ Rech. 29).

Até aqui, foi possível traçar o panorama da estrutura metafísica do jovem Leibniz, uma espécie de primeiro atomismo leibniziano, ainda fortemente inspirado pela simples combinatória. Foi possível ver o papel dos requisitos para a criação; isso com o auxílio das noções de compatibilidade e incompatibilidade, dois conceitos predominantes nesta fase, que se relacionam às idéias de consistência e de essência/existência. Isso pôde apresentar Deus como a sede de todos os elementos mais simples. O intelecto divino comporta tudo que há de positivo - simbolizado pelas coisas mais simples - e extrai um determinado conjunto dentre eles, ligando-se diretamente ao estado mais harmônico: o mundo mais rico em essência e, portanto, o existente. Isso oferece o panorama de parte do pensamento de Leibniz em meados de 1670.

Nada é sem razão por apresentar todos os requisitos suficientes. O que existe só pode estar presente no mundo se alcançar uma quantidade suficiente de combinações das suas notas. Em seguida, deve ser compatível com os outros "seres" que também compõe o mundo mais elegante. As complicações da Confessio aparecem pelo fato de Deus ser a sede de todos requisitos e também principal (único) responsável por reuni-los. Procurar a razão ou causa das coisas é orientar-se diretamente para o Criador, inclusive quando se pensa o estado harmônico daquelas. Deus seria, então, a causa indistinta de tudo? Ele seria tanto causa do que é bom quanto do que ocorre de mau no mundo? Isso retoma aquele problema anunciado inicialmente: Deus como o único responsável pelo mal, pois as supostas ações livres do restante dos seres apenas encobririam uma razão do mundo (PRS), que assegurava formalmente o lugar de tudo o que ocorre no universo criado.

Leibniz toma um velho exemplo: a traição e condenação de Judas (Conf. 36/37). Por que Judas cometeu o seu grande erro? Ele realizou por si mesmo, ou o seu ato 
foi algo inevitável? O Filósofo Catecúmeno afirma que o discípulo realizou a sua má ação porque pôde e porque quis (Conf. 38/39), ou seja, este detinha os principais elementos que orientavam a ação. Devido uma inversão e por uma espécie de ódio em relação às coisas divinas, Judas teria buscou o seu erro, o que lhe tornou a ação digna de "escolha". Mas com aquele conceito de harmonia, tributário do PRS, que orienta o mundo, e por Deus apresentar-se como a fonte exclusiva de racionalidade, o outro personagem, o Teólogo Catequista, elaborou a grande objeção do texto:

«Le péché provient d'un pouvoir et d'une volonté. Le pouvoir vient de Dieu, la volonté de l'opinion ; l'opinion, tout ensemble de empérament et de l'objet l'un et l'autre venus de Dieu; donc tous les réquisits du péché viennent de Dieu; donc la raison dernière du péché comme toutes les autres choses, donc, aussi, de la damnation, c'est Dieu $\gg($ Conf. 40/41 - grifo meu).

Logo, ao ser a última razão das coisas, sujeito de todos atributos simples, Deus não deixava de ser a razão do mau. Se ele é o autor do mundo, ele parece participar da autoria das imperfeições inerentes à sua criação ${ }^{21}$. A justificativa do Filósofo se desintegra na argumentação do seu interlocutor; as razões da ação de Judas não estariam realmente em sua posse, pois a sede destas estaria numa fonte exterior, e não no "próprio agente". Tanto o objeto de escolha e o ambiente do seu ato já lhe aguardavam de maneira fixa e intocável, sem que algo pudesse mudar a ocorrência dos fatos, ou seja, tudo estava em completo acordo com o estado harmônico. As ocorrências que aguardavam Judas se enquadravam na armação subjacente ao mundo, pensado e criado por Deus. Como aquela criatura poderia ser culpada de tal peso que caía sobre suas costas? Leibniz procurou salvar a figura divina ao tentar mostrar que a sua primeira resposta, "poder e vontade em Judas", podia ser mantida. Será que o fundamento metafísico sustentava suas pretensões morais?

Em linhas gerais, a Confessio apresenta idéias próximas às argumentações formuladas posteriormente por Leibniz ${ }^{22}$. Mas se é justo afirmar que algumas respostas já estavam razoavelmente delineadas na perspectiva teológico-moral, o mesmo não se pode dizer em relação à metafísica. Para resolver essa disparidade, Leibniz lutou para alcançar

\footnotetext{
21 A disposição do espírito de Judas, o objeto de escolha, as circunstâncias nas quais ele se deparou e a própria vontade de errar teriam como fonte o próprio arquiteto do mundo, e não qualquer outro ser. Essas características, inerentes a qualquer ação livre, ainda não poderiam ser realmente atribuídas às criaturas.

22 A Confessio já faz referência ao próprio Aristóteles, assim como foi feita na Teodicéia em 1710 (Conf. 60/69 e T 34 e 288).
} 
uma formulação metafísica que corroborasse com implicações morais desejáveis, como no caso da absolvição de Deus. É preciso notar mais pontualmente, por meio da Confessio e dos outros textos parisienses, onde estariam as falhas que precisavam ser revistas.

O PRS, dominado pela simples somatória dos requisitos, não parecia assegurar de maneira absoluta a presença de uma legítima noção de vontade tanto do lado de Deus, e ainda menos do lado das criaturas. Deus existe porque é a totalidade dos requisitos, os atributos positivos, ou seja, ele tem máxima essência; tudo o que existe segue o mesmo princípio, não por ter a totalidade dos requisitos, como o criador, mas por se aproximar do máximo. O mundo existe porque atinge o maior grau de essência dentro da combinação dos elementos simples e, aparentemente, ganha o direito de efetivação. Há uma impressão de que a máxima inteligência identifica o plano mais rico, e de que este existe quase de imediato. Deus opera internamente esse mecanismo, ou melhor, ele praticamente se iguala a este. Várias coisas levam a uma aproximação muito forte entre harmonia e vontade (e praticamente à suplantação desta), sem que haja uma distinção entre ambas (A VI iii 588/ DSR, 113). Porém, haverá realmente uma vontade neste caso?

Leibniz não deixa de citar conceitos como o de vontade, contingêncialpossibilidade e liberdade (Conf. 54/55). Teria ele direito? É preciso retroceder até a mente divina para comp rovar se esses três elementos ainda participaram efetivamente da origem do mundo. Alguns pontos ainda conspiram contra os propósitos do autor.

Deus não seria o autor do mal porque apenas identifica a presença dessa falha nas partes do mundo mais harmônico. Dentro da combinação dos elementos positivos, o mundo mais rico em compatíveis aparece de imediato. Mas ao contrário do criador, os próprios constituintes do mundo não alcançam o máximo de essência, sobretudo quando são tomados numa perspectiva particular. Isso abrirá espaço para as imperfeições, e junto a elas, o mal. Assim, mesmo o melhor plano possui o mal, ou as más ações, que além de fazer parte da essência do mesmo, ele contribui exatamente para a principal característica daquele: ser o melhor. Assim como as sombras e as dissonâncias auxiliam a produção artística, o mal integra o mundo mais rico.

Entretanto, a máxima ciência não é a única responsável pela perfeição de Deus. Ele é perfeito porque alcança o topo de tudo o que é passível de receber um valor máximo; 
ele alcança o último grau naquilo que se dá a tal característica ${ }^{23}$. Assim, ele não apenas deve perceber o melhor, como também deve efetivar o melhor, por ser o Ser que é. O estado de harmonia do mundo também reflete Deus, pois o estado de perfeição daquele espelha a onisciência deste. Há um jogo de reciprocidade da razão entre Deus e o mundo criado; a razão (intelectual) é o ponto de identidade entre ambos ${ }^{24}$. A própria natureza divina caracteriza-se por ligar-se ao que há de perfeito. E se isso ocorre pelo lado de Deus, isso deverá valer para o oposto, ou seja, se este mundo não for como tal, o mais harmônico e possuidor do mal, isso poderá significar que o seu arquiteto é outro, e não Deus. Esse argumento já seria dos mais fortes, visto que é de forte inspiração lógica ${ }^{25}$.

A vontade divina não participaria de maneira alguma na elaboração da criação? Tudo apareceu apenas porque Deus existe? Como Deus poderia querer algo? Com a argumentação que foi apresentada, fica difícil sustentar a presença de vontade em Deus, o que não permitiria a idéia de uma origem moral do mundo. Deus não criou tudo o que era possível, mas tudo que existe parece ter sido a única opção de escolha. Pode-se dizer que a totalidade do espaço de possibilidades não é realizável - a idéia de compatibilidadeincompatibilidade e o próprio princípio de não contradição (PNC) asseguram isso - , mas aquilo que não foi efetivado ainda não mereceria a denominação de possível. $\mathrm{O}$ intelecto $e$ o poder divinos não deixariam tanto espaço para o seu querer. Um não seria realmente destacado do outro. Seria indiferente se fosse a vontade ou o entendimento que governasse as coisas existentes. Além disso, no mínimo, a vontade é "arrastada" pelo entendimento; ao final, bastava ao mundo ser orientado exclusivamente pelo princípio da harmonia (Conf. 64/65).

Judas ainda poderia ilustrar a responsabilidade das criaturas? Não era necessária a ocorrência da traição? As coisas complicar-se-iam ainda mais. Em contraposição a isso, Leibniz já tentava atenuar o peso da necessidade por meio da necessidade alterius

\footnotetext{
${ }^{23}$ Cf. DM I e GP VI 602.

24 Como está escrito acerca da criação no Discurso:

"Isto (as palavras das Escrituras) é tanto mais verdadeiro quanto é pela consideração das obras que se pode descobrir o operário. Portanto, é preciso que estas obras tragam em si o caráter de Deus” (DM, II).

Mas a Confessio não mostra argumentos suficientes quando procura atribuir o caráter de louvável para a criação.

${ }^{25}$ Isso pode ser facilmente explicado da seguinte maneira: se A implica existência de B, a não efetivação de B pode implicar a não existência de A (Conf. 46/47).
} 
hypothesis. Como se pôde notar, por não possuírem uma razão em si mesmas, as criaturas dependem de uma razão externa, ou ser de existência necessária, que garanta a estruturação do mundo e a existência daque las.

«( ...) il est faux que tout ce qui suit de l'être par soi nécessaire soit par soi nécessaire. Certes, il est constant que de propositions vraies ne résulte que le vrai.(...) Des choses existantes ne suit nécessairement que Dieu; tout le reste que suit de la série de choses supposée, c'est-à-dire de l'harmonie des choses, ou de l'existence de Dieu, est par soi contingent et seulment hypothétiquement nécessaire, encore qu'il n'y ait rien de fortuit, puisque tout découle de la destinée, c'est-à-dire d'une raison déterminée de la providence» (Conf. 54/55).

Essa argumentação também aparece no pensamento maduro de Leibniz: necessidade em si e necessidade ex hypothesis; esta depende da realidade necessária de uma causa. Porém, ela não saía ilesa da objeção anterior pelo fato das criaturas não serem suas próprias razões. Elas acabavam por receber um destino inflexível, que as acompanha desde a origem do mundo. A transitividade de necessidades seria fatal, pois quando há identificação estritamente intelectual de uma opção, o estado mais harmônico, que constrange a vontade (divina) a criá-la em vista da perfeição, tudo o que está no interior de tal alternativa não deixará de se efetivar de uma maneira absoluta. Os próprios requisitos bastam para engendrar a existência. Ao final, e este será o grande problema a ser resolvido: o que a onisciência mostra é o que será realizado, sem que haja a intervenção de uma verdadeira escolha.

As ações das criaturas corroboram a composição deste mundo da pior maneira para elas e mesmo para Deus. O mundo é o que é porque elas são necessariamente de tal e tal maneira, antes mesmo do decreto. Para adiantar outro detalhe, os objetos almejados e as supostas disposições daquelas são constitutivos da ordem das coisas. Seria, então, o fim da liberdade? Não é o que Leibniz procurou mostrar, pelo contrário, elas deveriam agir da maneira como quiserem, mesmo que estejam numa série totalmente arrematada. As ações também ocorrem em meio às coisas existentes devido a presença suficiente dos requisitos. Como Deus tem acesso a todos os atributos positivos, ele conhece cada ação e sabe que todas fazem parte deste plano harmônico.

Ainda na Confessio, O Teólogo queria entender como poderia haver liberdade junto à máxima ciência divina. Então, num último esforço, ele lançou um grande dilema. 
Frente a frente com Deus, o que ocorreria se o perguntasse: "para qual direção moverei meu braço" (Conf. 70/71)? Se ele apontasse para um lado e o movimento realizado fosse diferente, a liberdade estaria assegurada, mas Deus apresentaria uma imperfeição. Se o movimento fosse absolutamente aquele que Deus apontou, sua ciência seria conservada às custas da liberdade da criatura. "Ou a pré-ciência ou a liberdade é suprimida" (Conf. 72/73).

A resposta do Filósofo Catec úmeno foi imediata, sem que trouxesse a resolução cabal do problema. Quando Leibniz fala em liberdade, ele entende ser "impossível" (incompatível) não realizar o melhor quando este é identificado e quando nada impede sua realização; no geral, essa idéia será preservada posteriormente (e será visto na parte final). Contudo, é dada uma ênfase a outro detalhe, através do Filósofo, que parece responder porque Deus antevê tal ação e porque esta não poderá ocorrer de maneira contrária à previsão. Ainda continuando aquela passagem sobre "o movimento do braço", o Teólogo afirma ser livre na medida em que pode fazer um movimento diferente do previsto e afirmado por Deus; o Filósofo responde o seguinte:

«Cette chicanerie est subtile, mais, de toute manière, elle n'aboutit qu'à ceci: l'âme qui serait de cette nature, qu'elle veuille et qu'elle puisse faire ou vouloir le contraire de ce qui pourrait être prévu par quiconque, est au nombre des entités qui sont incompatibles avec l'existence de l'Être omniscient, c'est-à-dire avec l'harmonie des choses, et qui, par suite, n'ont pas existé, n'existent pas, n'existeront pas»(Conf. 72/73, grifo meu).

Tudo indica que o tom final da resposta é dado pelo mesmo jogo dos requisitos da arquitetura. Apesar de referir-se à vontade das criaturas, esta não está apartada da soma dos atributos positivos. A existência depende apenas do grau das essências, o mesmo ocorrendo no caso das ações, sem que haja "preferência" por qualquer coisa. Se algo é feito por tal criatura, é porque houve a convergência de certos atributos, que estão de acordo com o estado harmônico deste mundo, o melhor e, consecutivamente, o existente.

Leibniz, após algum tempo, ficou ciente dos riscos que estava correndo. No De Libertate, ele próprio compreendeu que não estava no caminho certo para associar a liberdade ao PRS. 
«Pour ma part, à l'epoque où je considérais que rien n'est fait au hasard ou par accident, si ce n'est relativement à certaines substances particulières, que la fortune separée du destin n'est qu'un nom vide de sens et que rien n'existe si ce n'est lorsque sont posés les réquisits singuliers (or il suit de ces réquisits, lorsqu'ils sont tous conjoints les uns aux autres, que la chose existe); j'étais peu éloigné de l'opinion de ceux qui jugent que tout est absolument nécessaire, qu'il suffit que la liberté soit préservée de la contrainte bien qu'elle demeure soumise à nécessité, et qui ne distinguent pas le nécessaire et l'infaillible, c'est-à-dire du vrai lorsqu'il est connu avec certitude » (FC 178/ Rech. 329- grifo meu).

O resultado disso para a liberdade, principalmente a divina, seria sua redução a praticamente dois dos seus ingredientes: inteligência e espontaneidade (talvez nem isso no caso das criaturas). Bastava a convergência de certos elementos e a falta de qualquer empecilho para a ação; este seria o critério geral de existência e, portanto, das ações das criaturas. Na continuação dessa passagem, Leibniz afirma que foi retirado do abismo em que estava prestes a cair por oferecer uma verdadeira cidadania aos possíveis não realizados.

A Confessio já apresentava alguns avanços. Ela delineava claramente o que já eram as principais pretensões de Leibniz acerca da liberdade (além de uma eodicéia), apesar de não mostrar tal paridade entre suas intenções e o arcabouço metafísico. O filósofo não mostrou ir muito além do que fora escrito a Wedderkopf (1671 - A II i 117-118/ L 146$147)^{26}$, p. ex., onde, mesmo a contragosto, a necessidade absoluta se mostrava inevitável para Deus. Nesta carta, Leibniz apresenta uma idéia de liberdade com toque fortemente intelectualista. Não realizar o melhor seria fruto de ignorância ou fraqueza. Essa era a forma que ele encontrou para combater a liberdade caprichosa. No caso de Deus, não havia outra saída: Ele tem posse do melhor, identifica-se com ele e é impossível que faça diferente; o oposto existe apenas enquanto nome, e não como alternativa legítima, mesmo com a postulação daquela segunda incompatibilidade (o conceito de incompossibilidade ainda inconsistente, como será visto). Era inconcebível cogitar qualquer coisa que arranhasse o ser perfeito: se ele viu o melhor, mas não realizou, foi por fraqueza, e perde a onipotência; se não ponderou tudo previamente e apenas criou qualquer coisa, não é onisciente. Em poucas palavras: "se não faz o melhor, não é Deus". Na Confessio, mesmo que a contingência não seja um ingrediente fundamental para a liberdade, ela já tem algum

\footnotetext{
${ }^{26}$ Indicação de Adams (1993, pp.129-130).
} 
destaque, mas ainda inferior ao que virá nos escritos posteriores. Mas isso ainda não é o ponto central a ser perseguido neste momento.

O próximo passo é notar como Leibniz procurou mostrar que o mundo não é um processamento interno ao seu artífice (sujeito de todas as perfeições), ou um mero combinador, em que os diferentes níveis de essência implicam uma realidade imediata, ou seja, onde se apresentar como o melhor seria idêntico a ser decretado. Também há necessidade de assegurar um verdadeiro modelo de ação das criaturas, única maneira de mostrar que elas não são meros acidentes, mas contribuem para o resultado do mundo como verdadeiros agentes. É preciso ver como Leibniz buscará recuperar a idéia de moralidade na própria origem do mundo, pois Deus ainda está reduzido à onisciência e à onipotência. Resumindo: para que Deus seja totalmente inocentado, novos detalhes devem ser acrescentados no intuito de garantir sua vontade. Se ele não for causa do erro, quem seria(m)? Quem seria(m) o(s) verdadeiro(s) pecador(es), que poderiam eliminar a culpabilidade divina? É preciso notar até que ponto as criaturas têm o poder sobre suas ações. 


\section{2. VERDADE, SUBSTÂNCIA E AÇÃO}

A soma suficiente dos requisitos e o forte teor intelectualista não foram as melhores soluções, ou pelo menos as mais completas para realizar a distinção das ações, o que levava àquele grande problema moral: Deus como causa indistinta de tudo, inclusive do que há de ruim. Se uma ação é fruto absoluto do encontro suficiente dos atributos positivos, sediados no intelecto divino, sem que nenhum outro ser participe dessa composição, o único responsável nessa história seria o próprio criador. Na Confessio, o autor procurou mostrar que Deus não participaria do mal por não ser causa imediata do mesmo, e sim as criaturas. São nítidas as dificuldades em tal afirmação, pois como foi visto, tornar Deus causa da totalidade das coisas por um lado, e limitar esse poder por outro, não é algo muito viável, principalmente no campo dos atributos positivos. Tornou-se difícil sustentar que Deus é causa moral de qualquer coisa, inclusive do bem. Enquanto construtor do mundo mais harmônico, Deus não seria muito diferente daquele ser uno, para quem tudo não passaria de sua operação interna, sem que as idéias de vontade e possibilidade tivessem relevância.

Leibniz entendeu que foi resgatado do precipício quando realmente incorporou os possíveis ao seu sistema (FC 178-179/ Rech. 329-330); mesmo as coisas não coroadas com o decreto deviam permanecer possíveis (impossibilidade apenas acidental), o que já era afirmado nos anos parisienses. Entretanto, é difícil não pensar que Leibniz "fora salvo" daquela espécie de necessitarismo, oriunda do puro jogo dos requisitos, devido às infinitas substâncias. Como foi visto, os elementae simplices eram operados apenas por Deus, no seu intelecto. Ao final, o melhor (adequado à perfeição geral divina) não oferecia outra real alternativa que a efetivação.

É possível começar a entender os motivos das mudanças realizadas no campo metafísico ao serem observadas as críticas endereçadas à Espinosa. Em uma correspondência enviada a Bourguet, em dezembro de 1714, Leibniz afirma se distanciar de qualquer acusação de espinosismo devido o seu conceito de substâncias, distinto do monismo (GP III 575). Segundo Leibniz, para Espinosa, havia uma única substância, da qual tudo era ontologicamente indistinto. Leibniz, ao contrário, veio a entender que existem infinitas substâncias, verdadeiros seres. A crítica seria basicamente a seguinte: 
«Il (Spinosa) aurait raison, s'il n'y avait point de monades; alors tout, hors de Dieu, serait passager et s'evanouirait en simples accidents ou modifications, puisqu'il n'y aurait point la base des substances dans les choses, laquelle consiste dans l'existence des monades »( GP III 575 - grifo meu).

A substância espinosista não abre espaço para a afirmação de outra(s) substância(s), e tudo se reduz às simples modificações daquela. O homem, por exemplo, seria formado pelo modo pensamento e pelo modo extensão. Na Ética, os homens não têm uma substancialidade própria, mas apenas participam da totalidade do mundo, onde a substância se encontra imanente. Seria um erro falar em seres. Fora o único ser, haveria apenas acidentes ou simples desdobramentos da única substância, sem que tivessem uma verdadeira realidade por si. Isso foi um grande alvo para as críticas de Leibniz ${ }^{27}$.

Leibniz procurou distinguir a realidade e as ações dos seres simples com relação à sua fonte de realidade. Ele entendeu que no caso da "substância una" espinosana, é visível a não separação entre as ações desta e as ações dos modos, pois seriam um único e mesmo ato, ou seja, tudo seria interno ao único ser. No sistema espinosista, as ações são originadas da própria auto-realização da substância, que também pode ser chamado de Deus.

Outro detalhe, criticado por Leibniz, acerca do Ser espinosista é a sua não operação a partir de um campo de possibilidades, visto que tudo aquilo que existe não deixa de ser único; se é "possível", não deixará de ser real. Para Espinosa, a idéia de algo na mente divina já é portadora de realidade de modo semelhante às propriedades que derivam do conceito de triângulo. Ser uma idéia em Deus é sinônimo de existir ${ }^{28}$. Não há possíveis (não realizados) para Deus, sem contar que ele não tem vontade, um atributo que ilusoriamente faz parte das mentes fantasiosas das criaturas. Deus possui apenas poder e intelecto, pois com a ausência de vontade, ele não precisa ponderar entre vários caminhos

\footnotetext{
27 «La 'Nature naturante' produit en elle, en son sein des modes infinis comme elle, et qu'il est très difficile, remarque Leibniz, de différencier d'elle; ces modes infinis comprennent en eux un ensemble infini de modes finis ; cepedant chacun de ces modes n'est produit que par un autre mode, selon une série de causes dont la produtivité n'est autre que celle de la substance elle-même, à la fois causa rerum et causa sui. On conçoit bien que cela donne lieu à l'interrogation cruciale de Leibniz dans notre texte : 'Mais comment sortiront-elles enfin de Dieu ?' (Leibniz, p.38), si elles ne peuvent sortir ni médiatement ni immédiatement de Dieu. L' existence est en effet, pour Leibniz comme pour les scolastiques, un « être hors de sa cause'» (M. de Gaudemar (1999), in: Réfutation inédite de Spinoza, p. 73).

${ }^{28}$ «L'enjeu est massif: assurer l'autonomie des existants singulier concrets, distingués d'êtres purement notionnels comme les êtres géométriques. Une séparation doit avoir lieu entre les individus et leur origine, 'ens realissimum', de façon à fonder l'individuation et l'existence réelle de ces êtres» (M. de Gaudemar, idem, p. 70)
} 
possíveis de criação; basta que “algo", única via, lhe venha à mente para que seja contemplado com a realidade.

No período parisiense, Leibniz estava muito próximo das características do seu oponente. Mesmo que as idéias de um Deus extrínseco ao mundo e a de possibilidade não tenham demorado a ter lugar no seu sistema, ele via muitas coisas do judeu ateu entrarem no seu próprio sistema. A carta endereçada a Wedderkopf (A II i 117/ L 146-147) ainda apresenta um pouco dessa característica. Mesmo falando em possíveis, Deus, ao se deparar com o melhor, não teria outra (verdadeira) alternativa que criar o objeto do seu intelecto ${ }^{29}$, sem que pudesse fazer diferente. $\mathrm{O}$ melhor mundo seria praticamente associado a Deus, e qualquer alteração naquele podia acarretar uma mudança no conceito do segundo ${ }^{30}$. Porém, essas questões dos possíveis e da vontade divina devem ser tratadas melhor mais à frente, pois antes é preciso mostrar como Leibniz pôde desprender realmente as infinitas substâncias de Deus e, assim, os outros detalhes aparecerão naturalmente.

Leibniz diz em outra passagem:

«Quant à ce que dit Spinoza (Ethique, I, prop. 34) que Dieu est de la même nécessité cause de soi et cause de toutes choses, et (Traité politique, chap. II, §2) que la puissance des choses est la puissance de Dieu, je ne l'admets pas. Dieu existe nécessairement, mais il produit librement les choses. Dieu a produit la puissance des choses, mais elle est distincte de la puissance divine. Les choses opèrent elles-mêmes, bien qu'elles aient reçu les forces d'agir» ${ }^{31}$.

Leibniz sempre concordou com Espinosa no ponto em que Deus é um ser necessário, i. é, Ele tem uma realidade absoluta (único ser em que a essência se identifica à existência). Entretanto, eles se divergem quanto ao significado do poder de ação das criaturas, além da própria noção de possíveis. Para Leibniz, não seria adequado falar em ação das criaturas no sistema de outro dos seus melhores inimigos, pois tudo seria mera reprodução do poder divino, e jamais uma ação distinta deste.

Contra tudo isso, Leibniz notou a necessidade de criar um espaço de equilíbrio entre as ações divinas e as das criaturas, sem a ocorrência de um conflito entre os dois campos. Assim, ele encontrou uma saída nas infinitas substâncias, ou como se encontra no

\footnotetext{
${ }^{29}$ cf.C 24. Como também foi afirmado por M. de Gaudemar (1999, p. 79), há uma diferença entre o fiat possível, obtido pelo cálculo, e o fiat efetivo: "lá décision de créer n'est pas lé résultat du calcul".

${ }^{30}$ Cf. supra n. 25.

${ }^{31}$ Réfutatio inédite de Spinoza, 27.
} 
oitavo artigo do DM: "Para distinguir as ações de Deus e das criaturas, explica-se em que consiste a noção de uma substância individual" (grifo meu). As substâncias individuais foram o marco para que as criaturas deixassem de ser meros acidentes. Num sentido geral ${ }^{32}$, os infinitos seres possuem como principais características a completude, a unidade e uma legítima espontaneidade. Eles também são dotados de máxima distinção e são indestrutíveis (imperecíveis).

A primeira intenção de Leibniz foi pensar em algo que livrasse os seres dos prejuízos da matéria e da extensão e, assim, não sofressem as mesmas instabilidades que ocorrem no campo sensível (GP IV 473, 478 e 482); e isso vem de longa data.

Quem vier acompanhando até este ponto, pode pensar que a idéia madura de substância é absolutamente inédita até meados de $1680^{33}$. Antes de prosseguir, é preciso responder negativamente. Não se pode ignorar que, inicialmente, o pensamento leibniziano é totalmente permeado por teses que se apresentam de maneira intuitiva, mas que pouco a pouco ganham lugar efetivo no seu sistema ${ }^{34}$. Um destes casos será visto agora.

A formulação da substância individual tem o seu esboço já nos textos teológicos de Leibniz nos anos de 1668 - 1669. No Sobre a Transubstanciação (L 115), Leibniz já mostrava a insuficiência de se tomar apenas a matéria como base para a explicação da transformação do pão e do vinho no corpo e sangue do Deus filho; nesse escrito, ele já invocou aquilo que estava fora de moda para os modernos: as formas substanciais, mas ainda igualadas às substâncias corporais. Havia substâncias compostas a partir de uma matéria e de uma alma. No caso dos homens, sua substância era pensada como composta por sua alma e seu corpo, e no caso do restante dos seres, havia uma matéria somada ao espírito divino que gerava sua substancialidade.

Logo, em seguida, já nos seus primeiros anos de Paris, Leibniz se dedicou fortemente aos estudos sobre a origem do movimento. Sem se contentar que as explicações de tal assunto fossem baseadas apenas na extensão e na geometria, ele percebeu a necessidade de incluir seres indivisíveis e inextensos que fossem capazes de fundamentar o movimento dos corpos, como pode ser lido na sua Teoria Motus Abstracti (GP IV 228/ L 138). Mesmo com a manutenção da matéria na formulação das substâncias (corporais) - o

\footnotetext{
${ }^{32}$ Que já deixo claro: é o mais importante para o meu propósito.

${ }^{33}$ Cf. Garber (1982).

${ }^{34}$ Leinkauf, pp. 260-262.
} 
que levou muito tempo para o autor abandoná-las (o que perdurou inclusive no DM XVI XVII) -, um elemento do campo metafísico se tornou essencial na conceitualização dos movimentos, já que os estudos inspirados apenas na geometria estavam longe de alcançar um nível satisfatório de explicação. O filósofo alemão também já procurava resolver os problemas envolvidos no labirinto do contínuo.

Assim, "a nova" concepção de ser, a substância individual, tem muitas características vindas desde os períodos indicados até aqui, das quais Leibniz nunca abriu mão. Entretanto, o seu aparecimento não deixa de ser um dos momentos de grande relevo no seu sistema, ou um momento em que Leibniz levou várias das suas primeiras idéias ao limite. Em primeiro lugar, o ponto chave está na infinidade de indivíduos completos. $\mathrm{O}$ ponto alto da explicação do conceito de substância individual ocorre com o princípio de inesse, uma idéia absoluta de verdade: "o predicado contido na noção do sujeito de toda proposição verdadeira” (FC 179; C 16-17/ Rech. 339). Tudo isso não era algo tão fácil de ser aceito, chegando a assustar um dos principais interlocutores de Leibniz, Antoine Arnauld, pois ao contrário do que desejava Leibniz, a sua tese não afastaria a idéia de um fatalismo de tudo o que surge no plano existente, além de pôr um fim à libe rdade das ações de Deus. Vale a pena acompanhar um pouco dessa discussão.

O princípio de in-esse foi pensado como válido universalmente na concepção de Leibniz, ou melhor, ele deveria valer tanto para as verdades expressas ou necessárias, como para as verdades de fato (C 16-18/ Rech. 339-341). A característica geral da verdade é a inserção do predicado no conceito do sujeito, independente da modalidade de proposição (FC 179). E essa conexão, sempre a priori, permite que um ser, dotado de máximo intelecto, possa ver todas as verdades, inclusive as que se dão no campo da existência e que podem ser entendidas apenas de maneira empírica no caso das criaturas (indemostrabilidade), portadoras de um intelecto limitado. A partir do dito princípio, é possível dizer que toda substância contém a totalidade das suas propriedades na sua natureza, i. é, um conceito completo. Dito isso, é possível introduzir as duas modalidades de proposições que acompanharão esta dissertação até o seu desfecho.

Existem as verdades de razão, cujo predicado é abarcado pela noção do sujeito de maneira expressa. Uma proposição necessária mostra claramente a conexão que ela representa, p. ex., "a soma dos ângulos do triângulo resulta em $180^{\circ}$ " pode ser claramente 
identificado a partir da própria proposição ou ser demonstrado, independente da existência ou não de triângulos. Basta a identificação do enunciado para que a verdade logo apareça. Nesse tipo de proposição, a afirmação oposta é absolutamente falsa, pois que "a soma dos ângulos internos do triângulo seja diferente de $180^{\circ}$ "é algo visivelmente contraditório. O in-esse se revela automaticamente (DM XIII; FC 181- 182/ Rech. 332; C 16- 17/ Rech. 339- 340).

Por outro lado, há proposições relacionadas a uma suposta existência, e que não são idênticas ao modelo de proposição anterior, já que a afirmação oposta não é eliminada. Que "Leibniz viaje para Paris" não exclui a opção pela "sua não viagem”, pois esta permanece possível. Todavia, conforme o princípio do in-esse, uma das opções ("a viagem” ou "a não-viagem") já participa da "noção de Leibniz", assim como todos os demais predicados desta modalidade. Como é um ser de visão infinita, Deus conhece a priori cada predicado que se encontra na noção da criatura ou não (GP II 19). Assim como há convergência de proposições necessárias, também há convergência de um determinado conjunto de proposições relacionadas à existência em algum sujeito, até que este seja o ponto de junção da totalidade dos seus predicados. Inspirado por esse pensamento, Leibniz começa a delinear a substância individual. Uma substância individual tem a totalidade das suas propriedades em sua natureza, e a partir disso, o autor procurou trilhar uma maneira de escapar dos problemas vistos acima (DM VIII).

Porém, não é difícil perguntar: o que validaria a idéia do in-esse? Em termos de método, Arnauld não concordou muito com essa idéia porque considerava imprudente, visto que Leibniz desenvolveu um conceito de substância que tem como fundamento um conhecimento fora de si mesmo, via intelecto divino (base do PRS), e não a partir do critério de clareza e distinção, base adequada para o conhecimento verdadeiro por parte do sujeito. Nessa linha de inspiração cartesiana, Arnauld entendia que os seres deveriam ser pensados apenas em função daquilo que "posso ter certeza", neste caso, daquilo que lhes é absolutamente essencial. "Ser homem” ou "ser que pensa” são exemplos de propriedades que poderiam integrar "Adão", pois seria contraditório pensá-lo sem qualquer um deles. Isso pode ser distintamente entendido. Mas a "a viagem" ou "a não-viagem" de "Leibniz" não contribuem de maneira permanente para o ser de Leibniz, não passando de meros acidentes. 
Leibniz não tirava os méritos de uma investigação interna, mas também não considerou que isso fosse suficiente no que diz respeito às verdadeiras unidades substanciais $^{35}$. O autor da Teodicéia valeu-se da mente de Deus sem maiores problemas. Como ser indiferente ao conhecimento de Deus em relação às coisas? Era certo que não se deveria buscar os motivos que impeliram Deus a construir as coisas, porém não ser tocado pelo máximo símbolo da razão parecia uma irracionalidade. Desta maneira - também por inspiração teológica - Leibniz levou o princípio do in-esse até as últimas consequiências. A substância individual ganhou cidadania, pois a nova idéia de verdade assegurou a completude da noção de todas as legítimas substâncias. Pode-se dizer que a falta da propriedade "ser racional" que se conceba "Leibniz", e que "a sua não realização da viagem" não tem o mesmo efeito, ainda no que se refere à sua noção específica (neste momento, pensada em termos de propriedades necessárias). No entanto, se Leibniz "não realizar a sua vigem", que está definida para ocorrer no momento $t$, ele desaparecerá enquanto indivíduo, reconhecido por Deus, cuja noção indicava "a ocorrência da viagem" em tal dia. Como escreveu Leibniz em 14 de julho de 1686:

«(...) si je ne fais pas ce voyage, cela ne combattra aucune vérité éternelle ou nécessaire. Cependant puisqu'il est certain que je le ferai, il faut bien qu'il y ait quelque connexion entre moi, qui suis le sujet, et l'execution du voyage, qui est le predicat, semper enim notio predicati inest subjecto in propositione vera. Il y aurait donc une fausseté, si je ne le faisais pas, qui detruirait ma notion individuelle ou complète, ou ce que Dieu conçoit ou concevoit de moi avant même que de resoudre de me créer ;(...) (GP II 52).

\footnotetext{
35 (GP II 53). Arnauld não deixou de valer-se dos preceitos cartesianos com relação ao conhecimento. Como afirma C. A. Moura, Leibniz combate constantemente essa idéia de "sentimento interno", visto que não é tão evidente quanto postula ser. A suposta noção de "clareza e distinção" fundamentou a cisão do conhecimento, fazendo com que houvesse um tipo de saber pertencente a Deus, que deveria ser apartado das investigações filosóficas. Mas a "luz natural" não se valeria de critérios tão rigorosos quanto se pensava. Ela é que se aproximaria mais da "imaginação". C. A. Moura, ao tratar da questão da "liberdade de indiferença" entre Descartes e Leibniz, deixa isso bem claro (2004, p.262):

"O método já tinha de tal forma sancionado o seu uso, este 'sentimento interno' já se confundia de modo tão integral com a própria evidência, a 'interiorid ade' já se identificava de tal forma à racionalidade, que não havia nada de mais 'natural' do que consultá-lo em qualquer ocasião. Do ponto de vista leibniziano, era este extravio básico que condicionava todos os demais" (neste caso, seria 'a liberdade de indiferença', mas isso também vale para o caso das verdadeiras substâncias e, mais adiante, para os possíveis).

Esse assunto exige uma análise mais acurada de ambas as obras, de Descartes e de Leibniz, acerca do método. Os textos de C.A. Moura (2000, 2003 e 2004) e de E. Forlin (2003, cap. VI) oferecem um bom panorama sobre essa controvérsia.
} 
As substâncias são resguardadas por seus conceitos (GP II 52), trazendo todas as suas propriedades, independentes da suas existências ou não, e estão abertas ao intelecto divino. Manter estas formas de unidade é extremamente importante para que se possa dizer que "o Leibniz que foi para Paris" é o mesmo "Leibniz que está na Alemanha" (GP II, 4243). "Todos os predicados devem estar num mesmo sujeito (insunt eidem subjecto)" e, assim, todo ser é conservado em virtude do seu conceito. Essa é uma das principais intenções do autor.

As palavras de Leibniz esclarecem a importância do princípio de in-esse para a viabilidade da formulação das substâncias individuais. Quando passaram a ser entendidas em termos de completude (sujeitos completos), as substâncias puderam receber uma explicação consistente ${ }^{36}$. E esse princípio oferecia o novo tom do lema leibniziano: nada é sem razão. Agora, deve-se dizer que, em qualquer verdade, sempre haverá uma razão ( $a$ priori) na conexão de um sujeito com certo predicado, seja uma verdade de razão, cuja conexão é manifesta, seja uma verdade de fato, cuja inserção do predicado no sujeito caracteriza-se como virtual (DM VII e XVIII).

O in-esse é critério geral para qualquer proposição verdadeira e é garantido pelo intelecto divino, que tem acesso direto a qualquer verdade. Todos os seres possíveis têm conceitos absolutamente completos. Disso implica que a falta de qualquer um dos predicados nos seus interiores ocasiona o desaparecimento dos seus conceitos de seres. Assim, cada substância tem uma noção integral e indivisível. Nada pode ser extraído da sua idéia seja enquanto possível, ou enquanto existente. Se Deus cria, tal fato ocorrerá, visto que tal noção já inclui os predicados que indicam previamente o seu futuro.

Uma substância deve ter um conjunto absoluto de atributos suficientes para lhe dar o caráter de unidade, sem que haja o risco de ser dividida em outros seres, ou ainda de poder compartilhar o seu conceito com mais de um uma substância, o que seria impossível $^{37}$. Qualquer conjunto de predicados que não conseguisse engendrar uma única

\footnotetext{
${ }^{36}$ Isso vai além da definição por simples distinção (sujeito independente): a substância como sujeito de vários predicados sem que ela seja predicado de outro sujeito (DM VIII); o princípio apareceu para acabar com qualquer definição apenas nominal. Caracterizar a substância individual daquela forma não fornecia uma resposta conclusiva. Com isto, Leibniz vai além dos pensamentos de Aristóteles: a substância é definida intrinsecamente por todas as suas propriedades (Lopes dos Santos, 1998, pp. 107-109; Moura, 2000, pp. 3537).

${ }^{37}$ Agora a distinção não se dá em termos de espaço e tempo da forma em que aparecia ao final da Confessio $(104 / 105)$.
} 
noção absolutamente completa poderia ser caracterizado como conceito para mais de um sujeito (sub ratione generalitatis). Ao contrário disso, "cada substância é o exemplar único do seu conceito". O princípio do in-esse oferecia ao conceito de cada substância as noções de completude, a máxima inteligibilidade e a máxima distinção. O mundo e o campo dos possíveis foram enriquecidos pela diversidade infinita dos seres que os compõem. Uma substância individual se destaca completamente das outras. Por isso, era inaceitável o modelo de substância proposto por Arnauld, já que não delimitava um indivíduo em termos de totalidade predicativa. A suposta noção de substância, para o francês, seria formada a partir da eliminação de todos os predicados que não são, por assim dizer, orientados pelo princípio de não contradição. No sistema leibniziano, a substância sugerida por Arnauld, noção específica (“...comme je n’ai qu'à consulter la notion spécifique d’une sphère...”; GP II 32), não servia como critério de diferenciação, pois assim como as espécies, aquela pode ser compartilhada por mais de uma substância. Pelo lado de Deus, como este tem uma visão perfeita de tudo, ele deve identificar qualquer noção substancial de maneira integral e deve notar as diferenças entre elas. Portanto, se um dos predicados de uma substância não estiver presente no seu conceito, Deus percebe imediatamente que se trata de outro ser.

Deus é onisciente e a própria noção da verdade (in-esse) implica a completude das noções individuais. Essas duas teses são as faces da idéia de máxima inteligibilidade das coisas. Ele tem uma ciência perfeita porque elas se apresentam integralmente enquanto verdades, mesmo o que não é necessário. O criador representa a razão que abarca não apenas todo o mundo, como também todas as noções possíveis. O intelecto divino e o princípio do in-esse andam em paralelo. As noções, localizadas na mente divina, não são exatamente objetos da sua criação, ou seja, como Deus não é o próprio autor do seu intelecto, o que exigiria outro ser anterior para fundamentá-lo, aquelas não são criadas por serem contemporâneas a essa mente. Assim, elas surgem com o próprio pensamento de Deus. É possível perceber que a intervenção de Deus se dá de outra maneira e não diretamente sobre (todas) as verdades, ou ainda melhor, sobre os conceitos.

A inspiração cartesiana se instalou em Arnauld, enquanto ele discutia as questões do conhecimento humano e divino, porque ele pensava haver um problema ainda mais grave, oposto às pretensões de Leibniz: a substância individual não permitia a 
permanência de uma legítima vontade no horizonte divino. Para o filósofo alemão, as substâncias têm conceitos independentes, sediados no intelecto divino, sem que sejam montados voluntariamente. Já a vontade do criador tem a capacidade de efetivação dessas essências como foco principal. Na ótica do teólogo, isso impôs um limite ${ }^{38}$ para Deus, pois o criador, enquanto ser supremo, não precisava ter um intelecto destacado da vontade, pois o seu conhecimento caminharia em paralelo à mesma, ou melhor, a compreensão divina das coisas devia ocorrer de maneira simultânea à sua vontade e ação de criá-las.

Com efeito, Leibniz procurou provar o contrário ao responder esta grande inquietação de Arnauld: "os acontecimentos de uma substância individual, como no caso de Adão, dependem do arbítrio divino ou eles caem apenas sob o entendimento de Deus, como no caso da noção da figura do círculo?" Leibniz não viu a resposta como uma escolha entre as alternativas propostas, mas sim uma combinação de ambas (milieu). Mesmo que dependam da vontade divina para existir, a noção de uma substância independe de tal querer enquanto conceito completo. Um ser já mostra a integralidade da idéia existindo ou não. Deus é o único capaz de sediar essas noções passíveis de realização, mas esses seres não são simplesmente elaborados de modo volitivo ${ }^{39}$ (GP II 53). Deus é a principal (única) via para a compreensão e sustentação dos conceitos completos; ele é o único onisciente e é o único ente capaz de fornecer realidade aos mesmos. Apenas ele pode ser o responsável por duas formas de realidade, pela conceitual e pela efetiva.

«(...)c'est à mon avis, l'entendement divin qui fait la réalité des vérités éternelles, quoique sa volonté n'y ait point de part. Toute réalité doit être fondée dans quelque chose d'existant. Il est vrai qu'un athée peut être géomètre. Mais, s'il n'y avait point de Dieu, il n'y aurait point d'objet de la géométrie; et sans Dieu, non seulement il n'y aurait rien d'existent, mais il n'y aurait même rien de possible » (Th 184).

O arbítrio de Deus não participa de maneira ilimitada na constituição dos infinitos seres. Apesar das fortes diferenças entre essas duas zonas ontológicas, essa forma de pensar acerca das essências lembra, em parte, a maneira como Leibniz pensava o jogo dos requisitos (níveis de essência), já que a substância individual é pensada, num primeiro momento, em termos intelectuais. Não obstante, independente de Leibniz já ter pensado

\footnotetext{
${ }^{38}$ Marques (1998), p. 214

${ }^{39}$ Madouas, p. 375.
} 
numa dimensão de pura inteligência, onde há combinação dos possíveis, o in-esse possibilitou muitos avanços.

Já pode ser notado que o PRS não será mais oriundo de uma matriz apenas intelectual. O grande passo é mostrar que também há uma participação de uma vontade na origem do mundo, sem que ela seja a única que domine a produção de tudo, como no cartesianismo ${ }^{40}$. Logo, as infinitas substâncias já mostram a sua primeira função: colocar a vontade divina no seu devido lugar, sem renegar sua máxima ciência.

«(...) je dis donc, que la liaison entre Adam et les événements humains n'est indépendante de tous les décrets libres de Dieu, mais aussi elle n'en dépend pas entièrement de telle sorte, comme si chaque événement n'arrivait ou n'était prevû qu'en vertu d'un décret particulier primitif fait à son égard» (GP II 40).

Mesmo que sejam concebidas intelectualmente, as proposições de âmbito existencial podem tornar-se Verdadeiras através do decreto. As verdades contingentes estão sob a tutela do in-esse, mas sua possibilidade de efetivação depende do arbítrio divino para que se concretizem realmente como Verdades. Logo, o arbítrio de Deus opera exatamente neste campo de predicações, e não naquele em que a sua vontade não tem qualquer espaço de ação, nas proposições necessárias, ou mesmo no próprio espaço dos conceitos possíveis, visto que as verdades necessárias são absolutamente independentes e as noções, enquanto possíveis, dispensam a existência, ao contrário dos objetos (existentes) que elas integram (Th 184). A vontade divina se limita a efetivar o que o seu intelecto lhe apresenta: conjuntos de possíveis detalhadamente armados, dentre os quais um pode vir a ser decretado conforme o seu valor em relação aos restantes, ou como será visto, se for o melhor.

Leibniz considerava essa forma de vontade como satisfatória e adequada para Deus, ao mesmo tempo em que mostrou que o criador não concebe as coisas de modo fragmentado, e sim de uma maneira que combina com o seu intelecto; ele também pôde mostrar que Deus tem um verdadeiro espaço de volição, não de coisa por coisa, mas há eleição em meio a blocos possíveis. Entretanto, isso pressupõe outra implicação do conceito de in-esse: o que significam esses blocos de possíveis?

\footnotetext{
${ }^{40}$ Lopes dos Santos (1998), pp.100-101.
} 
"Cada substância reflete o seu mundo", ou melhor, é compossível em relação aos outros seres que o compõem. De alguma maneira, Arnauld negava a compossibilidade (agora não mais pensada apenas a partir de atributos simples, mas de substâncias), pois ele considerava que a idéia de expressão também estava no pacote de coisas abusivas em relação à liberdade divina. Pensar que uma substância é um sujeito portador todos os seus predicados, além de envolver todos os outros seres na sua noção, seria passar dos limites. Por outro lado, Leibniz entende que se uma substância já possui tudo no seu interior, inclusive os fatos contingentes, então, ela reflete as noções das outras substâncias que participarão com ela do grande teatro do mundo. Em suma, como as coisas não se apresentam de modo desconexo à mente divina, mas na forma de vários conjuntos possíveis - em função da noção de substância individual -, Deus opta por um desses blocos de substâncias (GP II 41). Isso parece gerar uma imposição das coisas à sua vontade, mas de fato é muito mais digno para ele. As substâncias possuem noções integrais e também trazem a compossibilidade no seu íntimo, sem que Deus precise pensar e criar coisa por coisa.

Um detalhe que o autor do $D M$ sempre ressaltou foi a característica divina de não tomar decisões isoladas, visto que Deus sempre optou por criar (ou simplesmente refletir) as substâncias em um conjunto que lhes fosse próprio. Ele não realiza o mundo de maneira miraculosa, ou seja, não toma decisões em paralelo aos acontecimentos. Como ele identifica os conceitos fora do tempo (Th 225$)^{41}$, de modo imediato, ele não precisa tratar cada uma das substâncias isoladamente, mas todas juntas e em harmonia. Não é porque Deus optou por este Adão que tudo seguirá a partir da noção do mesmo, como se as coisas fossem pensadas apenas em sua função. Se o futuro está assegurado após a criação do primeiro homem, é porque todas as outras personagens envolvidas no destino de Adão também foram objetos de uma reflexão prévia e simultânea. Como o próprio Leibniz exemplificou, Deus é como aquele príncipe sábio que opta pelo melhor general, não apenas pelo fato da competência deste, mas também porque um bom general optará por bons coronéis e bons comandantes para o exército que lhe será incumbido (GP II 19). Logo, a escolha do príncipe não se limitaria a uma, mas encadearia algo muito mais amplo, da mesma maneira como ocorre na mente de Deus.

\footnotetext{
${ }^{41}$ Lopes dos Santos (1998), pp. 96 e 111.
} 
As informações dadas acima indicam o campo de atuação da vontade de Deus e um pouco do modo como ela opera. Resta introduzir outros detalhes sobre o papel deste atributo importantíssimo. Ali, em meados dos anos parisienses, Leibniz estava muito ligado à região da compatibilidade e incompatibilidade no sentido estrito ${ }^{42}$, ou região das puras essências $^{43}$.

Pelo que já foi visto e conforme foi afirmado por Gueroult ${ }^{44}$, tudo indica que $a$ vontade de Deus tem lugar assegurado exatamente junto à configuração da região dos compossíveis, espaço que ganhou através das infinitas substâncias, apesar da primazia do intelecto divino. Mas além de participar da efetivação do melhor mundo, que é o seu ponto alto, a vontade não está totalmente apartada armação do universo. Em primeiro lugar, um mundo possível é montado na mente divina; ele pode ser pensado independente da sua existência desde que não esteja completamente alheio à possibilidade de existência, algo alicerçado na vontade do criador. Isso não era visto na região dos compatíveis, já que parecia haver o império de uma simples combinatória dos infinitos atributos positivos, que já tendia para o resultado mais harmônico e que engendrava uma existência de maneira imediata (ainda mais com o império absoluto do intelecto divino).

Uma substância é composta pela totalidade dos seus predicados, divididos entre os específicos (por exemplo: "ser que pensa para homem") e aqueles de âmbito espaçotemporal (o caso da suposta "viagem de Leibniz..."). Independentemente da modalidade de predicação, aquela ela todos os seus predicados. Mesmo que a noção daquela já indicasse que tal predicado lhe pertence, é preciso que Deus forneça lhe realidade. As verdades absolutamente necessárias se apresentam imediatamente, bastando serem pensadas, assim como o núcleo que elas formam. Já as noções completas (sub ratione possibilitatis - GP II 39), além de terem o seu núcleo necessário, também têm predicados de cunho espaçotemporal. $\mathrm{O}$ in-esse se liga às verdades necessárias devido uma razão intrínseca ao conceito destas; o que é garantido pelo próprio PNC. Já as verdades de fato dependem de algo que garanta a realidade efetiva destas. Em suma, é preciso que Deus queira a realidade do ser (de conceito completo) ao invés de outro (GP II 46).

\footnotetext{
${ }^{42}$ Para utilizar uma expressão de Fichant (1998, p. 111)

${ }^{43}$ Gueroult, "Substance and...", p. 247.

${ }^{44}$ Gueroult, op. cit. Conf. nota supra 9.
} 
Nas suas explicações para Arnauld, Leibniz mostrou como a vontade divina está no horizonte da armação de um mundo, e introduziu novamente o meio-termo da sua argumentação (associação entendimento e vontade) para manter a própria noção de possibilidade (uma escolha possível):

«(...)je dirai un mot de la raison de la différence qu'il y a en ceci entre les notions des espèces et cettes substances individuelles, plutôt par rapport à la volonté que par rapport au simple entendement. C'est que les notions spécifiques les plus abstraites ne contiennent que des vérités nécessaires ou éternelles, qui ne dépendent point des décrets de Dieu (quoiqu'en disent les Cartesiens, dont il semble que vous mêmes ne vous êtes pas soucié en ce point; mais les notions des substances individuelles, qui sont complètes et capables de distinguer entièrement leur sujet, et qui enveloppent par conséquent les vérités contingentes ou de fait, et les circonstances individuelles du temps, du lieu, et autres, doivent aussi envelopper dans leur notion, prise comme possible, les décrets libres de Dieu, pris aussi comme possibles parce que ces decrets libres sont les principales sources des existences ou faits; au lieu que les essences sont dans l'entendement divin avant la considération de la volonté» (GP II 49 - grifo meu).

Mesmo com a independência das noções, detectadas pelo (intelecto do) criador, é necessário pressupor a ocorrência de uma escolha de Deus enquanto este reflete acerca da melhor alternativa para a criação. "A viagem de Leibniz para Paris" é possível em função de um suposto decreto, mesmo que a noção daquele filósofo se apresente integralmente à mente do criador, junto aos seus outros predicados específicos e totalmente independentes, como o caso do "ser homem". Mesmo que a existência se lgue apenas a um grupo de proposições, isto é mais do que suficiente para demonstrar alguma relação de dependência da substância em relação à vontade de Deus, mas desde que feitas todas as ressalvas possíveis. O Deus leibniziano é distinto do cartesiano. Para este, a criação fica incumbida à vontade sem limites; naquele, o decreto ainda tem o máximo intelecto como eixo principal (não exclusivo).

Antes de prosseguir, é importante dizer que a passagem da região da compatibilidade (estrita) dos primitivae simplices para a dos compossíveis não está livre de dificuldades. As análises "astutas" de Gueroult procuraram comprovar que o núcleo está exatamente na aparição da vontade divina, que não tinha muito espaço no campo dos elementos simples (visto na primeira parte). Esta zona mostrava problemas na maneira de 
combinar seus elementos ${ }^{45}$. Sem uma resposta clara de Leibniz para a grande transição territorial, o que me força a realização de um salto, o fundamental é guardar o papel da vontade divina (o momento em que aparece e como se efetiva) e notar como a combinação, nos mundos possíveis, ocorre por meio de seres completos (sujeitos da totalidade de seus respectivos predicados $)^{46}$ em um processo intelectual que pressupõe uma criação possível.

É fato que Deus deve agir da maneira que melhor lhe convém, enquanto ser perfeito. Antes, parecia que o intelecto e o máximo poder eram suficientes para representar o criador. Mas o ganho seria muito restrito se tal processo fosse tratado de maneira imediata, ou seja, "ver o melhor e, caso nada impeça, realizá-lo" não permitia um julgamento moral da obra divina. A criação não passaria de um processo mecânico. Com as infinitas substâncias, é possível afirmar a presença de um campo de possibilidades, detectadas pelo intelecto, que se apresentam de maneira ordenada à vontade divina em função dos seus graus de essência, ou de riqueza ontológica; como o criador é predisposto a perseguir o melhor, devido à sua bondade, ele busca aquilo que está no topo dessa pirâmide de possíveis: o melhor (Th 414). Portanto, o PRS não se limita à associação entre conhecimento e poder. Como afirma Leinkauf ${ }^{47}$ : o mundo criado não depende apenas de uma razão lógica, mas também de uma razão moral.

\footnotetext{
${ }^{45}$ Basta ver os problemas que são gerados ao se falar da compatibilidade e incompatibilidade dos elementos simples (cf. os textos de Gueroult, o de Fichant -1998 e o de C. A. Moura - 2003 mostram isso). Qual seria o critério de negação na compatibilidade? Eles se apresentam como totalmente compatíveis entre si, e até mesmo convergem na prova da existência de Deus: sujeito de todos atributos positivos (A VI iii 575s/ DSR 97s); por outro lado, Leibniz não negava a idéia de incompatibilidade no campo dos elementae simplices.

${ }^{46}$ Isso não eliminou o espaço dos elementos estritamente simples na seqüência da filosofia leibniziana, eles ainda eram base de tudo. Leibniz não os renegou, basta conferir alguns textos em que ele teorizou sobre o conhecimento, mesmo os posteriores aos anos parisienses (GP VII 205/ O 190; GP IV 422/ O 271; DM XXIV); porém, não tiveram o mesmo destaque que recebiam inicialmente. As partículas elementares ainda foram vistas como os fundamentos do conhecimento ("ideal goal for science", Gueroult, "Substance and...", p. 237). Em muitos casos, mesmo quando se tratava do PRS, ele ainda utilizava o vocabulário dos elementae simplices. É visível que eles tiveram o seu papel diminuído ao longo do desenvolvimento da filosofia do filósofo alemão. Belaval resume bem o teor de todoa adificuldade em se conhecer o que há de mais simples, algo que é transmitido para o próprio conceito das substâncias (1962, pp. 266-267):

«La realité de l'essence individuelle s'exprime en une forme immanente à lindividu ; et cette forme d'une species infima doit, comme tout forme spécifique, exister (...) indépendamment de tou entendement créé. Nous pouvons connaître l'essence, mais, encore une fois nous ne pouvons connaitre que par prédicats, nous n'obtenons jamais que des pensées du réel: nous ne sommes pas créateurs, nous ne saisissons l'exprimé que par son expression. Toute union réelle, tout vinculum substantiale demeure pour nous un mystère. Nous ne saurions appréhender séparément le proprium quid qui fait de la substance un sujet véritable, et que Dieu pourrait « extraordinairement » séparer de ses prédicats ».
}

${ }^{47}$ p. 273 
Até aqui, viu-se a importância do novo conceito de substância na perspectiva divina. Por outro lado, já é preciso entrar no mundo das criaturas para compreender o que Leibniz quer dizer quando fala que cada substância representa o seu mundo ao contribuir para a elaboração deste, em função dos atributos que ela possui. Feito isto, será possível começar a entender como as ações podem ser imputadas às criaturas e de como é possível afirmar a presença de ligação entre elas. Por outro lado, não é muito claro como conceito de substância pode permitir qualquer idéia de relação.

Leibniz responde que, neste último ponto, existe uma maneira de dizer, visto que todos os seres são independentes uns dos outros; Deus apenas os vê todos em conjunto, mas mantém a particularidade de cada um. A partir da indepe ndência de cada noção, poderá ser dito que as infinitas substâncias têm apenas um encontro marcado, quando se pensa em suas ações, sem que uma tenha verdadeira influência sobre as outras. Surge outro aspecto do conceito de substância (individual): todo ser tira a ação do seu próprio fundo, sem qualquer influência externa, a não ser Deus, que fornece realidade (GP II 58; DM XIV e XXXII; GP IV 484). Assim, Leibniz pôde afirmar que qualquer ser agiria da mesma maneira se nenhum dos outros existisse, a não ser ele e o seu criador (DM XXXII; GP IV 485). O que o filósofo alemão fez foi atribuir para todos eles o que considerava uma outra conseqüência da nova noção de substância. Não é possível que nenhuma substância afete outra de maneira direta. O que há é um encontro de todas as ações com as das outras. A não impele, realmente, algum movimento sobre B; A se desloca para um certo ponto, onde B se encontra, e este se desloca por si, sem que A seja responsável pelo ato alheio.

O conceito de uma substância espelha um mundo no qual ela faz parte e age em conformidade com os outros seres a que ela se associa (GP IV 484). Leibniz afirmou isso para garantir a independência das ações (ou das noções), a espontaneidade, junto à dependência em relação ao criador, mas sem negar que houvesse uma relação harmônica entre todas as criaturas em um determinado mundo.

"É necessário, então, dizer que Deus criou primeiramente a alma - ou qualquer outra unidade real desse tipo - de um modo tal que tudo nela surge de sua própria natureza, por uma perfeita espontaneidade em relação a ela mesma e, entretanto, em perfeita 
conformidade com as coisas fora dela" (GP IV 484/ Sistema novo da natureza.., p. 26 grifo meu).

Não é difícil notar que algo chama imediatamente a atenção: como pensar uma substância como unida ao seu mundo, e o princípio que garante sua total autodeterminação? O conceito de compossibilidade parece propiciar uma idéia de causalidade no conceito da substância, o que feriria a sua noção. Esse problema é bastante tratado pelo autor quando este se depara com o ocasionalismo (Deus ex machina), um pensamento, não tão distante do espinosismo, e defendido principalmente por Malebranche. Grosso modo, o ocassionalismo é inspirado na filosofia de Descartes que, ao tratar do "problema moderno" da união alma e corpo - duas substâncias neste caso -, ele se valeu de Deus como o intermediador dessa relação. Quando a alma supostamente age sobre o corpo, seria na verdade Deus que realizaria o movimento deste; a alma seria encarregada apenas pela mudança de direção do seu corpo. Não é difícil perceber as críticas de Leibniz a tal pensamento, pois também seria difícil realizar a distinção entre as ações do Criador e as das criaturas.

Sem querer entrar diretamente na solução de Leibniz para o problema da "união alma e corpo", é preciso entender como o autor trata a questão da suposta relação entre as substâncias. Apesar de no sentido estrito, o metafísico, não haver qualquer influência de uma sobre a outra (Th 290, 296 e 400), o autor não descarta uma idéia de causalidade, mas apenas no mundo físico, o plano dos fenômenos, que não deixa de ser o ambiente (visível) das criaturas. Fora isso, a única forma de vínculo substancia ocorre a partir do princípio da harmonia (agora pensado termos de substâncias). Isso é essencial para entender o momento em que ele fala da presença de uma multiplicidade dentro da unidade: as percepções (Mon. 13 e 14). Independente de suas percepções nascerem do seu próprio fundo, uma substância pode espelhar o seu mund o através de percepções. Esse detalhe (índice de distinção, já que cada substância tem "as suas percepções" - Mon. 9) permite que surjam representações exteriores no interior da substância. Pode parecer inaceitável, pelo menos de imediato, mas Leibniz procurou mostrar que os seres podem se relacionar com o universo que os cerca somente pela via perceptiva.

As percepções permitem aquele modo de dizer, ou melhor, uma substância pode ter uma forma de acesso ao que se encontra no seu exterior. Elas estão na base daquilo que 
é conhecido como apetite, passagem de uma percepção para a outra (Mon. 15; GP VI 598). Os apetites fazem um ser tender ao movimento (impetus), e o que está fora não deixa de ter uma participação (indireta). Assim, surgem suas representações, "o inverso" das percepções, as quais permitem a captação dos outros seres (exteriores) ou a expressão daquilo que as cerca (GP IV 484) ${ }^{48}$. As representações fixam um eco ${ }^{49}$ do que se encontra fora da substância.

Cada substância tem acesso perceptivo a tudo que a envolve, formando representações de todo o seu universo. As representações que ela tem do mundo são algo que lhe é particular, o que faz Leibniz denominar essas perspectivas de pontos de vista, pois ela representa o universo à sua maneira. Isso criará um jogo de percepções e representações entre todos os seres que entram na formação de um plano possível. Um ser se apresenta (e também o mundo) ao seu modo, ao mesmo tempo em que identifica os outros seres (e o mundo) de uma maneira particular.

Como o tudo é pleno (GP VI 598), sem qualquer vazio (ausência de ser), cada substância se apresenta a todo o universo, o que permite dizer que sua ação repercute em todas as outras substâncias, pelo menos no campo ideal ${ }^{50}$. Os infinitos seres surgiram no momento em que Leibniz procurou as verdadeiras unidades das coisas (GP IV 478-479); já no caminho inverso, ele afirmou que a matéria surge nesse processo expressivo, no qual entram uma infinidade de seres reais. Com suas percepções/representações, as substâncias têm as suas ações articuladas de tal forma que geram o campo dos fenômenos. Eis que surge o plano material, expressão sensível do encontro marcado entre os seres.

Ainda que realizem apenas o que está em suas noções, sem se entrechocarem, nada impede que no plano sensível, abarcado pela física, se diga que uma coisa age sobre a outra. Uma substância age conforme sua noção. Ela mesma coloca as vias que irá seguir, pois age independente de qualquer fator externo, ou para usar uma linguagem de cunho aristotélico: ela mesma tem o seu princípio de ação (EN III 1). Na contramão disso, o

\footnotetext{
${ }^{48}$ Como nota N. Rescher no seu comentário à Mon. 60, in: G. W. Leibniz's Monadology.

49 Analogia que também dá idéia de uma imperfeição no interior das percepções, pois nunca são idênticas aos objetos externos; são apenasidéias (O 178-179).

50 Leibniz faz uma analogia no seu Primae veritates (p. 11) para deixar clara esta idéia de plenitude: «(..) nous voyons en effet dans un récipient empli de liquide (l'univers entier st un tel récipient) qu'un mouvement produit au milieu se propage aux extrémités, quoiqu'il soit rendu de plus en plus insensible au fur et à mesure qu'il s'éloigne davantage de l'origine».
} 
mundo físico, onde reina a causalidade direta entre os corpos, é mais adequado falar que há um império das causas eficientes em detrimento da finalidade.

$\mathrm{Na}$ perspectiva metafísica, as substâncias agem espontaneamente de maneira absoluta; ela se auto-orienta para os seus fins, já que segue os seus apetites. O apetite opera como a finalidade interna à ação da criatura, pois está ligado ao que é identificado como um bem. No espaço sensível, o popular, reina a idéia do movimento dos corpos a partir da influência de uma coisa sobre a outra, os choques. Apesar de falar em campo da verdade estrita (metafísica), da mesma maneira como Leibniz não renega a matéria, ele também não proíbe a relação de causalidade (Th 290), desde que limitada ao sentido popular. As relações causais também são as expressões "superficiais" daquilo que ocorre numa outra esfera. Isso fica claro quando ele fala acerca da ação e da paixão. Dentro da economia da linguagem popular, quando se fala que algo age é porque dentro da relação causal a coisa tem papel destacado dentro da ação, sendo-lhe atribuído o papel de agente. Por outro lado, o que é percebido como passivo seria o portador de um papel coadjuvante na ação, como se tivesse sido empurrado pelo outro, o agente. Porém, o modelo da mesa de bilhar é válido apenas para o os fenômenos, lugar da física (e da moral). Já no plano das verdades estritas, o que vale é a lei dos apetites ou das finalidades.

"Na mônada, as percepções nascem umas de outras segundo as leis dos apetites ou das causas finais do bem e do mal, que consistem nas percepções notáveis, reguladas ou desreguladas, assim como as mudanças dos corpos e os fenômenos externos nascem uns de outros segundo as leis das causas eficientes, isto é, dos movimentos. Assim, há uma harmonia perfeita entre as percepções da mônada e os movimentos dos corpos, preestabelecida de antemão entre o sistema das causas eficientes e o das causas finais, e nisto consiste o acordo e a união física da alma e do corpo, sem que um deles possa mudar as leis do outro" (GP VI 599 - grifo do autor/ "Princípios da natureza...", in: Discuso de Metafísica e outros textos, p.154).

O mundo material e as ações surgem como reflexo do que ocorre na dimensão da metafísica.

Já que esta passagem fala em corpos, é preciso dizer que seres viventes (plantas e animais) são compostos por um conjunto de substâncias bem ordenadas ou em harmonia. Uma substância reflete todo o mundo, mas de maneira confusa, pois ela se perde na totalidade do universo, que é uma imensa coleção de infinitas substâncias. Mesmo que reflita confusamente a totalidade do mundo, ela pode ter um melhor índice de expressão do 
corpo que integra. Nos animais, essa expressão é ainda mais adequada, pois as substâncias que entram na sua formação se organizam de tal maneira que se tornam um só ser: uma substância composta (GP VI 599). Nesse conjunto de substâncias, que forma os seres vivos, há aquilo que Leibniz chama de mônada dominante (ibidem), que funciona como um ser central, ao qual as outras substâncias simples estão subordinadas ${ }^{51}$. A mônada dominante está cercada por uma matéria, que na verdade também é um aglomerado de outras substâncias, e cria uma relação de domínio sobre elas.

Mas uma outra informação merece ser colocada: qual é o lugar dos homens na nova trama ontológica? Antes de qualquer protesto do leitor, pode-se perguntar o porquê das várias fases do conceito de substância serem tratadas de maneira indistinta, dado que o aparecimento da substância individual não foi suficiente para pôr um fim todo o processo de aprimoramento da filosofia (madura) leibnizina. Em primeiro lugar, isso pode ser justificado com um argumento básico: o objetivo aqui é oferecer subsídios para a "solução" do labirinto da liberdade, e não ao do contínuo; para este, a variação do conceito de substância é crucial. Foi visto que o conceito de substância está indireta ou diretamente ligado ao seu sistema há muito tempo. Além das várias características gerais, é importante notar que, mesmo não usando mais a idéia das substâncias corporais - critério de substancialidade utilizado até o final do séc. XVII ${ }^{52}$ - Leibniz sempre procurou manter um caráter de substância para os seres vivos em geral, inclusive para o homem. Apesar de não ser uma substância simples, ele é uma; ele tem uma mônada dominante que orienta a massa de substâncias que a cerca (alma).

Feitos esses esclarecimentos, é importante dizer que o homem vai além das demais substâncias simples por uma característica que lhe é peculiar: ele é dotado de apercepção (GP VI 599-600; Mon. 14). O homem tem percepções-representações, memória (também presente nos animais) e possui uma capacidade reflexiva. Se as percepções têm alguma relação com os objetos exteriores, conservadas as devidas ressalvas

\footnotetext{
${ }^{51}$ Isso já permite apresentar rapidamente da solução (madura) de Leibniz para a questão da união entre alma e corpo. Ele dispensa a necessidade de uma força miraculosa que realize tal ligação. Em primeiro lugar, principalmente nos últimos textos, isso não será mais considerado uma relação entre duas substâncias distintas, pois o corpo não será mais uma substância no sentido estrito; ele é apenas a expressão sensível do conjunto das mônadas que o integram. Isso permitiu o autor alemão afirmar a ocorrência de uma relação harmônica entre o que ocorre na alma (esfera metafísica) e o que ocorre no corpo (campo dos fenômenos).

52 Ou como diria Fichant (2000, p.32): elas começaram a entrar no anonimato, pois Alexandre, César, Judas entre outros já não terão o mesmo status de substancialidadade como tinham antes (substâncias simples); "Leibniz passou a não tratar mais os seres por um nome próprio".
} 
vistas acima, as apercepções são frutos de um processo interno ao sujeito no sentido mais forte que essa afirmação possa ser entendida. As percepções são a maneira como o sujeito "representa" o seu mundo (exterior), já a apercepção é modo como ele representa o universo, exclusivamente, a partir de si mesmo: uma expressão de si enquanto expressão do $m u n d o^{53}$. Os espíritos podem ter o conhecimento daquilo que é necessário, o conhecimento de si mesmo e o conhecimento de Deus.

"Mas o conhecimento das verdades necessárias e eternas é o que nos distingue dos simples animais e nos faz possuidores da razão e das ciências, elevando-nos ao conhecimento de nós mesmos e de Deus. É o que se chama de Alma Racional ou espíritos" (Mon. 29 - grifo do autor).

Logo, o homem tem algo que vai além dos outros seres, que apenas agem espontaneamente em função de seus apetites. O que entra nas simples representações é integrado a um processo intelectual. Devido à sua capacidade reflexiva, os espíritos podem ser comparados ao seu próprio criador.

Esses últimos detalhes permitem o arremate do quadro geral da ontologia leibniziana. As outras implicações serão apresentadas no que virá logo abaixo. Mas antes de serem introduzidas, é importante sintetizar o que foi visto até aqui.

No inicio de 1680, Leibniz iniciou um processo de sofisticação metafísica. O conceito de infinitas substâncias foi o seu grande aliado no momento de recuperar a vontade divina junto ao "desprendimento ontológico" das criaturas. Quando estas alcançaram o título de seres, e não mais o de meros acidentes, elas alto grau de autonomia. Deus não é apenas uma região que combina os primitivae simplices; ele também pondera sobre conjuntos de uma nova forma de unidade, a substância completa (e até mesmo na sua constituição, mas sem arbitrariedade). No que diz respeito ao homem, já seria possível começar "a responsabilizá-lo moralmente" nas coisas que faz, já que além de agir por si só, ele é capaz de "criticar" aquilo que percebe, podendo ou não fazer algo. Mas os outros detalhes sobre isso ficam para depois.

Ao final, outras coisas chamam a atenção. Uma questão, muito importante neste caso, seria saber como seria possível que uma criatura fizesse algo diferente daquilo que faz, pois é difícil sustentar sua capacidade de poder ir para outra direção, mesmo que ela

${ }^{53}$ Leinkauf, p. 270. 
tenha o seu conceito completamente acabado, chegando a refletir as noções dos outros seres que a acompanham. É preciso saber se as ações podem ser ditas contingentes, sem que as noções completas, fruto do in-esse, sejam afetadas, pois a máxima razão exige que elas possuam a totalidade dos seus atributos de antemão. 


\section{II}

\section{O PROBLEMA DA CONTINGÊNCIA}

Não basta reconhecer um bem e agir por si para que uma ação seja considerada livre. É preciso que haja legítimas opções de escolha. Se tudo fosse absolutamente necessário, estariam certos os que diziam que de nada adiantaria tentar fugir dos males, visto que ocorreriam independente do que fosse feito para evitá-los. Leibniz, porém, não concordava com isso que foi conhecido como o sofisma do preguiçoso (lógos árgos), o qual era imputado aos turcos (GP VII 391; Gr 363), que afirmavam não valer a pena abandonar os lugares assolados pelas pestes (Th 55); a desgraça seria inevitável. Não adiantaria tentar fazer qualquer coisa, pois consideravam ocorrer o domínio da pura necessidade. Assim, a aparição da contingência é o um outro passo para responder aqueles que defendiam o sofisma do preguiçoso. $\mathrm{O}$ destino não seria tão fatal a ponto de não haver possibilidade de agir de outra maneira. Quem se mantém estático e apenas espera pelo destino comete um equívoco. Não seria correto afirmar que tudo se realizaria independente da opção do agente, como se não houvesse outra maneira de fazer as coisas. Aqui começa um dos principais pontos da controvérsia.

Meu principal interesse é entender a contingência nas ações das criaturas, sobretudo nas racionais, o que exigirá a retomada e o aprofundamento de alguns pontos vistos anteriormente. Porém, é preciso voltar ao plano dos mundos possíveis, primeiro lugar onde a idéia de contingência deve se instalar, para que se perceba gradualmente se ela tem participação em todos os níveis do sistema de Leibniz, a começar pela origem. É aceitável afirmar que Deus escolhe entre uma infinidade de mundos que se apresentam ao seu intelecto, dentre os quais a vontade divina se encarrega de fornecer existência para algum dentre eles ${ }^{54}$.

A existência deste mundo não pró́be que se conceba a idéia de uma infinidade de outros planos, que poderiam entrar no seu lugar. As infinitas substâncias possíveis

\footnotetext{
${ }^{54}$ Leibniz entendeu que a decisão divina é tomada em um único lance, mas não se pode ignorar o fato de que ela se dá fora da esfera temporal, locus divino. Já a existência apenas reflete gradualmente aquilo que vem do campo atemporal, e tal transição depende do expediente de Deus. A criação não é um processo absolutamente imediato.
} 
entram na composição dos seus respectivos universos, também em número infinito. Arnauld considerava quimérica a idéia de possibilidade no horizonte do criador, nos moldes leibnizianos, e pensou que isso não passava de outro artifício. Pensar que Deus opta entre infinitos planos possíveis, conjuntos de infinitas substâncias, não combinaria em nada com a idéia de um ser perfeito, como é o artífice do mundo. Foram vistas as principais idéias que fundamentavam essa crítica; o teólogo francês pensava que não passaria de uma projeção antropomórfica sobre as ações do criador. Deus, como portador de um poder absoluto, não precisaria operar sobre as diferentes opções, fosse para conhecer ou para decretar. Pôde-se notar como Leibniz resolveu a questão do conhecimento divino, que respeitava a própria distinção entre as verdades que dependiam apenas do seu intelecto e aquelas que dependiam da sua vontade para existir. Mas todas eram identificadas intelectualmente, sem que fossem compreendidas voluntariamente.

Tudo leva a crer que todos os planos são igualmente possíveis, ou ao menos podem ser concebidos dessa maneira. Mesmo que os infinitos mundos não sejam compossíveis, eles não se auto-impedem enquanto opções de escolha. Eles apenas não podem existir em conjunto, já que a totalidade das coisas concebíveis não é realizável. Se assim não fosse, tudo existiria e a própria idéia de razão poderia ser eliminada (uma coisa ao invés de outra - Gr 305). Se existem infinitas proposições acerca de mundos possíveis, referentes às possíveis existências destes, que são abarcadas pelo intelecto divino, isso não significa que todas poderiam ser efetivadas com o decreto, apesar de não poderem ser menosprezadas enquanto alternativas legítimas. Se não houvesse vias alternativas, isso sim tornaria quimérica a idéia de liberdade (GP II 45). Logo, observou Leibniz, esses caminhos que são concebíveis em função de um discurso, não enqua nto existentes, têm o direito de serem chamados de possíveis.

«Pour appeler quelque chose possible, ce n'est assez qu'on puisse former une notion, quand elle ne seroit que dans l'entendement divin, qui est pour ainsi dire le pays des réalités possibles. Ainsi en parlant des possibles, je me contente qu'on en puisse former des propositions véritables, comme l'on peut juger, par exemple, qu'un quarré parfait n'implique point de contradiction, quand mème il n'y auroit point de quarré parfait au monde. Et si on vouloit rejetter absolument les purs possibles, on détruiroit la contingence et la liberté ; car s'il n'y avoit rien de possible que ce que Dieu crée effectivement, ce que Dieu crée seroit nécessaire, et Dieu voulant créer quelque chose, ne pourroit créer que cela seul, sans avoir la liberté de choix » (GP II 56 - grifo meu). 
Oferecer um puro voluntarismo para Deus e recusar os possíveis poderiam ocasionar um grande necessitarismo na a obra do mesmo, ou seja, negar que o criador pondere entre alternativas logicamente concebíveis e pensar que ele conhece e cria apenas em função da vontade sem limites elimina a idéia de contingência no mundo, inclusive nas próprias ações divinas. Segundo Leibniz, este é o ponto em que os cartesianos estavam próximos do espinosismo ${ }^{55}$. Eles queriam mostrar que Deus conhecia apenas o que ele queria; o reflexo disso é o fato do criador oferecer existência a tudo o que aparece na sua mente, o que eles chamavam de possível (Th 171). Como poderia falar-se em possibilidade nesse caso, visto que Deus efetivaria tudo o que surgisse na sua mente? Na interpretação do filósofo alemão, eles defendiam algo ainda mais absurdo, a saber, que todos os possíveis ganhariam realidade em algum momento e em algum lugar (FC 179; Gr 305). Até as maiores obras de ficção seriam reais algum dia desses. Leibniz dizia que, na perspectiva cartesiana, ninguém deveria assustar-se ao ver algum personagem de romance perambulando por aí.

A noção de possibilidade deve ser intrínseca a cada mundo, sem que ela dependa da vontade Deus. Ela está naquilo que poderá existir, mas não no que fornece realidade. Se a noção de possibilidade pertencesse apenas ao ser que tem o poder de criar, poder-se-ia dizer que é possível apenas o que o criador elege (GP VI 442). Se fosse dessa forma, nada seria possível a não ser aquilo que existe, ou seja, o que Deus elege; segundo Leibniz, isso foi o grande erro de Abelardo (Th 171 e 235). É preciso manter uma autonomia dos possíveis em relação à vontade de Deus para que haja razão na existência de alguns deles, sem que ela seja intrínseca a eles próprios. As opções divinas precisam ser necessariamente possíveis. Elas devem ser possíveis em si. Um mundo não trás a sua existência na sua própria noção, mas é possível de ser criado por si mesmo; ele se oferece a um possível decreto (GP II 51). Se não houvesse diferentes opções de decreto, dificilmente haveria alguma chance para a liberdade divina. Logo, Leibniz levou bastante a sério a necessidade de se conceber os possíveis não realizados, os quais são logicamente consistentes. Era preciso colocar efetivamente a tese da infinidade dos mundos possíveis perante o horizonte divino. A primeira parte mostrou como tal tese ganhou força ao longo do desenvolvimento da ontologia leibniziana.

\footnotetext{
${ }^{55}$ Moura (2003), pp. $271-274$.
} 
Tudo indica que a contingência consegue infiltrar-se no mundo por meio da idéia de possibilidade em si, e isso parecia valer para as substâncias que entram na composição dos seus respectivos mundos. Nada impede que se pense no "César que não atravessa o Rubicão", ao contrário de uma proposição matemática, absolutamente necessária. Uma coisa visível é que as proposições referentes ao "pecado de Adão", à "traição de Judas", à "travessia de César" etc. não são modelos de proposições em que qualquer afirmação oposta seja totalmente proibida. Posso dizer que "César não atravessa o Rubicão", mas não que "a soma dos ângulos do triângulo é diferente de $180^{\circ}$ ".

Outro detalhe acerca das proposições de ordem geométrica que chama a atenção é o fato de não dependerem da presença efetiva dos objetos no mundo existente. Elas mesmas trazem suas verdades, suas razões, de maneira intrínseca, sem que necessitem de algo além para se efetivarem como verdadeira ou qualquer exemplificação, a não ser suas próprias afirmações. Não há necessidade da existência de qualquer triângulo para que seja comprovado o valor da soma dos seus ângulos. Isto é uma situação oposta à das verdades de fato, que estão vinculadas à existência, que dependem da presença dos objetos no mundo para serem reais.

Como foi constantemente ressaltado, as verdades de fato pressupõem algo que lhes auxilie na sua efetivação; ao contrário das proposições necessárias, elas não têm uma razão (verdade e existência) intrínseca (Rech. 247). Isso é um dos principais pontos de diferenciação entre as duas modalidades de proposições que vêm sendo indicadas e que Leibniz referiu-se em boa parte dos seus textos. É essencial que haja um ente de existência necessária (o operador do PRS) para fornecer realidade aos seres, os portadores das verdades de fato.

Após os esclarecimentos realizados na primeira parte (e feitas todas as ressalvas), a Confessio pode auxiliar a compreensão de alguns detalhes sobre o problema da necessidade e contingência. O Teólogo Catequista apresentou uma questão das mais simples, mas que ainda é uma das mais emblemáticas (Conf. 54-57): do necessário não se segue o necessário? O Filósofo Catecúmeno procurou responder ao tentar colocar as coisas no seu devido lugar. Era preciso entender as noções de necessidade que estão envolvidas em tal afirmação. 
As proposições absolutamente necessárias trazem uma razão em si, ou seja, não dependem de nada mais do que de suas afirmações para se imporem como verdade. Por exemplo, mesmo que não existisse qualquer coisa, inclusive qua lquer círculo que pudesse exemplificá-lo, o número ? ainda teria o mesmo valor (GP II 50). Na contramão das verdades necessárias, as verdades de fato não trazem uma razão em si, ao contrário da sua idéia de possibilidade. Para que sejam coroadas como verdades efetivas (não meramente conceituais), elas dependem de um decreto possível, uma causa, para se tornarem reais. Elas existem caso o ser necessário queira que elas existam. Nisso Leibniz formulou aquela necessidade ex alterius hypothesis (Conf. 53-54). Essa forma de necessidade já fora indicada nos anos 70, ainda sem toda a força que ela encontrou a partir de $1680^{56}$.

«Des choses existentes ne suit nécessairement que Dieu; tout le reste qui suit de la série des choses supposée, c'est-à-dire de l'harmonie des choses, ou de l'existence de Dieu, est par soi contingent et seulement hypothétiquement nécessaire, encore qu'il n'y ait rien fortuit, puisque tout découle de la destinée, c'est-à-dire d'une raison déterminée de la providence » (Conf. 56-57 - grifo do autor).

Seria falso afirmar que o que é por si necessário gera algo também absolutamente necessário, mas o que é verdadeiro não deixa de originar o que é verdadeiro. Caso Deus opte por criar a alternativa oferecida pela máxima ciência, é certo que o fato ocorrerá, mas não porque este seja necessário em si. Essa questão fica clara com diferenciação aplicada entre a necessidade de conseqüência e a necessidade do conseqüente (Thk 14). Não é porque Deus optou por uma substância de noção completa que o futuro desta torna-se necessário por si; a conseqüência seria necessária, mas não o conseqüente $^{57}$. Será algo verdadeiro, mas desde que o ser de existência necessária queira a efetivação do conceito que lhe aparece. É certo que se uma substância individual A, portadora do conceito completo $\mathrm{C}$, for eleita, todo o seu futuro ocorrerá conforme $\mathrm{C}$, mas desde que Deus a conduza à existência. Em tal processo, o que é criado não apresenta autonomia absoluta para ser considerado totalmente independente do criador, pois isso significaria que a criatura seria portadora de um conceito necessário em si. É certo que as coisas não são de origem arbitrária, e sim são tributárias de uma máxima razão, que caso não seja totalmente em si, ela também depende de outra coisa. Em vista desse princípio, o

\footnotetext{
${ }^{56}$ Adams (1994), pp.136-137

${ }^{57}$ Ibidem, p. 134.
} 
autor pôde afirmar a presença prévia da verdade daquilo que deverá ser, mas sem a ocorrência de uma verdade absolutamente necessária. Deus opta por um conjunto de coisas que gradualmente ocorrerão no mundo criado, conforme os seus conceitos.

Segundo o autor, ocorrem muitos problemas por falta de esclarecimento sobre certos termos, tais como o de necessidade e de contingência. Em muitos casos, eles são utilizados sem que sejam conhecidas as idéias que os fundamentam. Por isso, era importante deixar claro que é necessário ou verdadeiro por si e aquilo que não é apenas em função do seu conceito, ou seja, aquilo que não é verdadeiro apenas em função de si. Desde que não sejam autocontraditórias, as verdades de fato, são possíveis em si, não necessárias em si ou verdadeiras em si, pois dependem da hipótese de uma causa.

Que este mundo, composto de infinitas substâncias, exista é algo absolutamente possível, contanto que Deus queira tal realidade. Apenas o criador tem existência absoluta. Ele é o único que existe pela sua própria necessidade, já que independe da hipótese de uma causa. O mundo não tem uma razão por si, mas depende que um ser de existência necessária (Mon. 37-39) opte pelo mesmo ${ }^{58}$.

Ao contrário das proposições necessárias e da existência de Deus, as proposições contingentes são necessárias ou verdadeiras em função da hipótese da causa. Mas algo chama imediatamente atenção: por que usar exatamente o nome de necessidade neste caso? Isso exigiria entrar no território metafísico e moral, o que deverá ser feito gradualmente, pois outros problemas merecem ser levantados em meio a esta tarefa.

A possibilidade em si estava fortemente ligada ao conceito de necessidade hipotética e já procurava oferecer algum espaço para a noção de contingência. Mas nem tudo parece fluir da melhor maneira para o terceiro ingrediente da liberdade. Todo ser tem a totalidade dos seus predicados conforme a noção geral da verdade formulada por Leibniz. Entender que uma substância contém todo o seu futuro no seu conceito não seria uma tese

\footnotetext{
${ }^{58}$ É preciso ficar claro que quando se fala em ex hypothesis, há uma forte referência à vontade divina, pois ela é o fundamento da existência de toda criatura.
} 
que se oporia a qualquer idéia de contingência e de ação livre? Ele mesmo tomou consciência das dificuldades.

"Dissemos que a noção de uma substância individual contém, de uma vez por todas, tudo quanto lhe pode acontecer, e que, considerando esta noção, nela se pode ver tudo o que é verdadeiramente possível enunciar dela, como na natureza do círculo podemos ver todas as propriedades que se podem produzir dela. Parece, porém, com isto, destruir-se a diferença entre verdades contingentes e necessárias, não haver lugar para a liberdade humana e reinar sobre todas as ações, bem como sobre todos os acontecimentos do mundo, uma fatalidade absoluta" (DM XIII).

No entanto, o autor procurou compatibilizar todos esses conceitos. Para ele contingência e liberdade não precisavam ser eliminadas apenas por causa da sua concepção de substância. Não era preciso considerar que havia atos livres à custa da máxima razão.

Já foi visto que Leibniz procurou acalmar os nervos do teólogo ao procurar mostrar que Deus ainda podia querer algo, mas numa perspectiva adequada à sua figura. Mas se ele assegurou a vontade e, em parte, a liberdade do criador, ele parecia não ter deixado qualquer espaço para a contingência e liberdade nas ações das criaturas. Ele até tentou, num primeiro momento, valer-se do modelo alternativo de necessidade, o que também foi alvo de protesto para Arnauld. A identificação da necessidade ex hypothesis não alcançou todo o efeito desejado e não chegou a um pretenso desfecho. O próprio teólogo confirmou que se valia da necessidade hipotética na sua argumentação ${ }^{59}$, apesar de não ver como o seu correspondente poderia sustentar que os fatos do mundo permanecessem hipoteticamente necessários. É certo que as ações de Deus foram poupadas da necessidade no decorrer da correspondência. Entretanto, no caso das criaturas, de que valeria dizer que suas ações são contingentes em função da vontade de um outro ser, sem

\footnotetext{
${ }^{59}$ Não se pode esquecer da figura do Intermediário, Ernst (landgrave de Hessen-Rheinfels), pois graças ao seu expediente é que a Correspondência entre Leibniz e Arnauld tornou -se possível, mesmo que o seu copista não tivera um papel tão nobre. Sleigh (1990) mostrou que isso teve alguma influência sobre a correspondência. As seguintes passagens deixam isso claro:

"Que la notion individuelle de chaque personne enferme une fois pour toutes ce qui luy arrivera à jamais etc. Si cela est, Dieu a été libre de créer Adam; mais supposant, qu'il l'ait voulu créer tout ce qui est depuis arrivé au genre humain, et qui luy arrivera à jamais, a dû et doit arrivé plus que fatale"(carta de Arnauld para Leibniz, in G II, p.15, grifo meu).

O mesmo trecho é reconstruído por Leibniz da seguinte maneira:

"Si cela est (savoir que la notion individuelle de chaque personne enferme une fois pour toutes ce qui luy arrivera à jamais), Dieu n'a pas este libre de créer tout ce qui est depuis arrivé au genre humain et ce qui luy arrivera à jamais doit arriver par une nécessité plus que fatale(il y avoit quelque faute dans la copie, mais je croy de la pouvoir restituer comme je viens de faire) (in G II, p.18).
} 
que elas tenham um legítimo poder sobre suas ações? Poderiam ser chamadas ações contingentes e livres? Foi dito que elas são portadoras das suas próprias ações, mas elas não parecem ter qualquer controle, por si mesmas, sobre os seus conceitos ou sobre a razão das suas noções.

"A travessia do Rubicão" já se encontra no conceito individual de César, e Deus conhece isso desde sempre. Que "César atravessa o Rubicão no momento t" já era algo previsível porque a noção completa de César inclui a propriedade independentemente de existir. Eis que isso levanta uma questão: era possível que "César não atravesse aquele rio em t”, mesmo que tal proposição tenha o direito de ser proferida? A afirmação de que tal verdade depende de uma outra vontade, e não a da criatura, ainda não era suficiente. A noção de substância comp leta, que parecia um verdadeiro aliado no momento de engendrar os possíveis e compossíveis, acabava por tornar-se uma grande vilã. Segundo o conceito de substância, o ser de César é absolutamente completo; o conceito do imperador inclui a totalidade das suas propriedades, inclusive a sua "travessia do Rubicão". Ora, caso esse imperador não realizasse o seu ato, ele alteraria o seu conceito de substância e invalidaria a previsão divina (GP II 52).

Leibniz, nas suas cartas para Arnauld, formulou sua idéia de substância individual, que além das suas propriedades necessárias, também possui os predicados de ordem existencial. Mas todos se encontram igualmente na noção dos seus respectivos sujeitos. Essa característica central das substâncias é transmitida diretamente para os mundos possíveis, visto que são compostos a partir de infinitas substâncias. Assim como a substância é portadora de todos os seus atributos, eles também são absolutamente completos; eles possuem a totalidade das suas substâncias, e cada uma delas possui todas as suas propriedades.

Até aqui não há tantas novidades em relação ao capítulo anterior, mas são detalhes que devem ficar bem guardados, pois é preciso notar se a contingência pode harmonizar-se com os outros detalhes do sistema. Deve ficar claro que, neste momento, o ponto da discussão não é exatamente se há participação da vontade de Deus na criação, pois há uma modalidade de propriedades que dependem do arbítrio divino para se efetivarem; apesar de que a comprovação da contingência dos fatos (fundamentada na necessidade hipotética) é importante para ratificar o que foi visto no primeiro capítulo, onde já fora 
introduzida a necessidade hipotética, mas em outra perspectiva. Daqui por diante, é necessário entender como a criatura pode fazer algo diferente ${ }^{60}$ do que está inscrito no seu conceito, e isso parece indicar que uma propriedade pode estar ausente da noção daquela, o que contradiz a tese central do conceito de substância.

Leibniz discutiu este ponto com Arnauld exatamente ao expor a déia de seres possíveis em si. Eles precisavam ser pressupostos para que as idéias de contingência e de liberdade fizessem sentido. Ele exemplificou isso com "o caso de Adão". É possível pensar em um “Adão que não peca, não casa com Eva, não mora no Paraíso etc”, e ainda pode-se pensar em uma infinidade de "Adãos" ${ }^{\text {61 }}$ que se distinguem do Adão existente. E haveria outros mundos possíveis em função das substâncias possíveis, já que elas entram na formação dos seus respectivos planos. Entretanto, além de valer-se das suas próprias teses, Arnauld insistiu na falha da argumentação leibniziana através da principal munição do próprio Leibniz: a substância individual.

O teólogo francês não via tanto sentido em postular a idéia de "Adãos" possíveis. Sob a ótica da noção completa, cada um desses “Adãos" seria um indivíduo diferente. Quando se postulava a noção de substância, por meio da noção completa, e concebia-se a noção de versões possíveis sobre o conceito daquela, isso parecia algo contraditório. Apesar de pensar de maneira distinta de Leibniz, Arnauld se valeu de um argumento trivial, visto que afirmava não entender como seria possível formular o conceito de uma substância, de natureza singular, de modo que ela servisse de referência para outro ser que não fosse ela mesma. Ou para deixar mais claro, como ele próprio questionou: como seria possível conceber vários "Adãos" juntos à idéia de um Adão, de natureza exclusiva? Arnauld utilizourse como exemplo para mostrar qual seria o grande problema: "seria como conceber 'eus' que se diferenciam do eu".

« Car je ne puis penser à moi sans que je ne me considère comme une nature singulière, tellement distinguée de toute autre existente ou possible, que je puis aussi peu concevoir divers moi que concevoir un rond, qui n'ait pas tous les diamètres égaux. La raison est, que ces divers moi seroient differens les uns des autres, autrement ce ne seroit pas plusieurs moi. Il foudrait donc qu'il y fût qulqu'un de ces moi, qui ne fust pas moi: ce qui est une contradition visible $\gg(\mathrm{GP}$ II, 30).

\footnotetext{
${ }^{60}$ Frankel, pp. 284-286.

${ }^{61}$ As aspas servem para diferenciar o Adão existente dos "Adãos" possíveis e do "Adão" geral.
} 
O correspondente francês não era partidário do uso abusivo da mente divina e nem permitia que Deus fosse visto como um criador orientado apenas pelo entendimento. Leibniz apresentou bons argumentos contra essa posição. Porém, o novo obstáculo ainda podia abalar fortemente o sistema, visto que Arnauld também considerou que o erro de Leibniz foi ocasionado pelo uso excessivo da imaginação ao se conceber "Adãos alternativos". Aparentemente, a objeção ganharia força e solução com o conceito de substância sugerido pelo próprio Arnauld, definida somente em temos do princípio de identidade. Se o conceito de Adão fosse armado apenas em termos dos seus predicados necessários, seria impossível pensá- lo sem qualquer uma das suas propriedades centrais. Seria impossível pensá-lo como "não animal”, p. ex.; por outro lado, ele poderia ser pensado como "não-pecador", sem que isso afetasse o seu conceito, isso ainda na perspectiva do teólogo ${ }^{62}$. Fundamentado por sua tese - substância individual em termos de predicados necessários - Arnauld pensou que se fosse tomada a idéia de substância puramente possível, poder-se-ia conceber um Adão que pensa junto à noção de um outro Adão que talvez não pense. Logo, se fossem detectados "Adãos" diferentes de Adão, isso significaria que algum predicado do segundo estaria ausente naqueles outros, o que seria uma contradição. Se C indicasse um conceito essencial de um indivíduo A, seria contraditório que houvesse um indivíduo, também A, para o qual não valesse o mesmo conceito C. Arnauld concluiu que o melhor, em tal situação, seria deixar de lado a idéia dos possíveis não realizados, pois não passariam de quimeras. Isso era óbvio para o caso de uma substância definida apenas em termos do princípio de identidade ${ }^{63}$. De alguma forma, isso podia ser transmitido para a substância elaborada por Leibniz, na qual todos os atributos encontram-se na noção do sujeito ${ }^{64}$. Mesmo que tenha sido assegurada a vontade de Deus, essa última questão ainda teve alguma validade, já que a resposta de Leibniz rõo foi totalmente eficaz na Correspondência.

\footnotetext{
${ }^{62}$ Cf. supra p. 37.

63 É perceptível que essa afirmação traz um pressuposto, a saber, que noção de substância formulada por Arnauld também serviria para delimitar um indivíduo. Segundo Sleigh (1990, p.57), isso não pode ser concluído por meio dos escritos daquele. Já foi visto que, conforme o pensamento de Leibniz, se uma noção for definida apenas pelo princípio de identidade, corre-se o risco da sua partilha entre mais de um ser, pois lhe faltaria o restante das suas propriedades. Arnauld não parece ter-se preocupou com esse problema.

${ }^{64}$ Elas não deixam de ter um grau de parentesco, pois ambas possuem os seus predicados a priori, mesmo que o grande trabalho de Leibniz fosse mostrar que a segunda noção, individual, não se reduz à primeira, abstrata (GP II 38-39).
} 
O princípio da máxima distinção das substâncias - conseqüência direta do princípio de in-esse - fortalecia ainda mais o argumento de Arnauld. A radicalização do conceito de substância eliminou qualquer idéia de diferença puramente numérica (DM IX; GP II 42 e VII 393-394 e 481). Uma noção completa é exemplificada por apenas um ser, pois a noção não pode ser compartilhada por mais de uma substância. Se houvesse duas substâncias com o mesmo conjunto de propriedades, elas seriam absolutamente idênticas e diferenciadas apenas numericamente. Porém, conforme o princípio da identidade dos indiscerníveis, se duas substâncias possuírem exatamente as mesmas propriedades, elas não passariam de um único ser. Isso fortalece ainda mais a idéia de uma substância conter a totalidade dos seus predicados em absoluto, ou ainda, toda propriedade da substância pode ser-lhe atribuída sempre de maneira exclusiva.

A vontade divina auxiliou a distinção entre verdades necessárias e verdades contingentes, pois as verdades de fato podem existir mediante uma suposta criação, ao contrário das verdades de razão. Mas é fato que mesmo as verdades contingentes encontram-se previamente na noção do sujeito, i. é, são proposições em que a ligação entre o sujeito e o predicado caracteriza-se como intrínseca. Arnauld considerou essa propriedade como sinônima de necessidade (GP II 28). Tudo estaria no interior do sujeito, fossem os atributos referentes ao passado, ao presente ou ao futuro da substância. Leibniz aceitou a idéia de todas as proposições serem intrínsecas ao conceito do sujeito, mas sem que significasse que todas fossem necessárias. E isto, ao final, não deixa de oferecer ainda mais certeza ao destino das coisas.

"Todo acontecimento futuro é futuro com a mesma certeza que o passado é passado. Não porque isso seja necessário por si mesmo, senão porque é derivado das circunstâncias presentes estabelecidas (por exemplo, a pré-ciência de Deus e, igualmente, a série das coisas). É verdadeiro, sem exceção, que tudo o que é futuro haverá de ser; tudo o que é verdadeiro é certamente verdadeiro (para aquele que sabe). Logo, é certo que tudo o que é futuro haverá de ser. Tudo o que é certo é inevitável. Tudo o que é inevitável é necessário. Logo, todo futuro é necessário. Mas, isso conforme uma necessidade por acidente ou hipotética, a qual me referia dizendo que certamente não suprime a contingência ou a liberdade" ${ }^{35}$ (grifo meu).

Há grandes dificuldades em entender tal afirmação, mas elas são ainda maiores quando se trata de pensar as verdades em termos de predicações essenciais e acidentais.

65 “Diálogo com o Bispo Esteno acerca da Liberdade", op. cit. p.186. 
Como pensar em acidente se tudo passou a ser intrínseco ao conceito do sujeito? Tudo seria essencial? No $8^{\circ}$ artigo do $D M$ (integral), o autor fez uma afirmação ainda mais intrigante: "uma substância individual tem uma noção tão completa que seria permitido deduzir tudo o que pertence ao sujeito ao qual ela é atribuída”. Como falar em dedução sem cair no puro essencialismo, ou ainda, no necessitarismo? Ora, foi possível falar em dedução porque de alguma forma Leibniz corroborou a acusação de homogeneização essencial e acidental, pois a noção individual eliminou essa diferença, ou pelo menos parte dela.

Segundo Lopes dos Santos, uma das conseqüências da concepção leibniziana de substância é a dissolução da distinção entre atributos essenciais e acidentais ${ }^{66}$, pelo menos em termos aristotélicos, e com a qual Arnauld parecia continuar de acordo. As duas modalidades de predicação passaram a ser pensadas a partir desta tese: existe um conjunto de predicados necessários que podem compor o núcleo de várias substâncias, mas todo predicado particular é essencial em relação ao conceito completo de alguma substância. A partir disso, Leibniz parece ter-se preocupado com a distinção entre sub ratione generalitatis e sub ratione possibilitatis na Correspondência ${ }^{67}$, e entre necessidade e contingência na maioria dos outros textos, mas não em termos de predicados essenciais e predicados acidentais; o que realmente lhe interessava. Ele ainda utilizou os termos essencial e acidental, principalmente referindo-se à esfera temporal ${ }^{68}$ (Gr 278; GP II 207), ou para deixar mais claro, a distinção entre o que é essência e o que é acidental passou a representar a distinção entre propriedades permanentes e propriedades não-permanentes. Ele procurou mostrar a diferença entre aqueles predicados que perduram no tempo e aqueles que se realizam em determinado momento, dependentes do decreto divino, mas sem deixarem de encontrar-se a priori em um conceito completo.

Já no $13^{\circ}$ artigo do $D M$, ele imediatamente buscou deixar claro o que ele queria dizer com dedução, para mostrar que isso não significava o fim da contingência. Todo o conceito de uma substância já estaria pronto, com todos os seus predicados no seu interior.

\footnotetext{
66 1998, pp. 105-110.

${ }^{67}$ Como escreveu Madouas (p.378):

"La distinction de l'accidentel et l'essential se déplace: la distinction entre essential et accidental revient à distinguer des propriétés omnitemporelles qui relévent précisément du niveau de compréhension de l'Adam vague - par exemple être homme pou Alexandre - et des propriétés qu'un individu possède à $\mathrm{t} 1$ mais pas à $\mathrm{t} 2$-par exemple pour Alexandre, être roi."

${ }^{68}$ Mondadori, pp. 277-279.
} 
Nem todo predicado pode ser apresentado a partir do conceito do sujeito, e mostrar isso também foi uma das grandes tarefas de Leibniz. Mas aqui se torna visível uma das grandes dificuldades que acompanham uma leitura dos textos desse autor. Na Correspondência (GP II, 20), p. ex., para ilustrar a máxima distinção entre as substâncias, Leibniz utilizou o exemplo da diferença entre a elipse e o círculo. Isso pode causar estranheza, pois essas duas figuras abstratas têm noções simples, ao contrário do caso das substâncias. Todavia, como Leibniz considerou as noções individuais como detentoras das suas predicações, neste aspecto, elas podem ser alvo de tal analogia, pois assim como as figuras geométricas se diferenciam de modo absoluto na matemática, as substâncias se diferenciam entre si. Assim, de alguma forma mesmo a noção de substância indicada por Arnauld representava parcialmente a idéia da substância completa. Uma noção específica não deixa de ser completa, mas dentro do limite das predicações a que ela se refere: apenas verdades absolutamente necessárias; a diferença é que o seu conceito é muito mais limitado do que o de uma substância. Não se deve esquecer a diferença entre a noção específica de esfera e a esfera do túmulo de Arquimedes. Mesmo a primeira tem certa completude enquanto espécie, o que lhe torna semelhante a uma substância, mas é a segunda que atinge o ápice da integralidade e da unidade ${ }^{69}$. Mas já foi indicado que ainda há diferença entre elas; segundo o pensamento de Leibniz, como ele procurou mostrar com o exemplos das esferas (GP II 53), existem predicados que integram a essência de várias substâncias, pois são predicados gerais, ou seja, são insuficientes para definir uma noção completa. Por outro

\footnotetext{
${ }^{69}$ É claro que esse exemplo da "esfera do túmulo de Arquimedes" não está livre de problemas, pois até que ponto esse objeto pode ser apresentado como similar a uma substância? Aparentemente, essa "noção individual" de esfera não está no mesmo patamar de Adão, exemplo indubitável de substância (Sleigh, 1990, p.55). $\mathrm{Q}$ exemplos de Leibniz, principalmente aqueles tomados da geometria, muitas vezes, geram uma confusão dos seus significados (a minha última tentativa de explicação mostra isso). Tomando a Correspondência e o DM, pode-se ver algumas amostras de como ele usou os exemplos da geometria de várias maneiras. Resumindo:

a. enquanto possuidor de uma noção completa a priori, Adão tem uma noção igual à da esfera, permitindo, assim, que se possa identificar todos os seus predicados da mesma maneira que as propriedades desta.

b. "Adão" tem uma noção igual à da noção específica de esfera, enquanto noção sub ratione generalitatis.

c. Adão tem uma noção equivalente à da esfera do túmulo de Arquimedes enquanto substância completa e, portanto, possui uma noção sub ratione possibilitatis.

d. Adão tem uma noção tão distinta, que pode ser diferenciada de qualquer outra da mesma maneira que a elipse se diferencia do círculo.

Parece surpreendente detectar problemas como este nos textos de alguém que teve tanta preocupação com o uso dos termos, apesar de que o autor procura, em alguns casos, explicar os seus exemplos de maneira mais adequada (cf. DM VIII e XIII e um opúsculo inédito traduzido por Sleigh (1990), Appendix C, p.195).
} 
lado, fora os predicados sub ratione generalitatis, sobram os predicados que são essenciais para os indivíduos, já que são intrínsecos a alguma noção completa. Ser geômetra e ser profeta são duas coisas distintas, observa Leibniz, pois a totalidade dos predicados não se reduz ao modelo das proposições geométricas ${ }^{70}$; nem todos os predicados são permanentes. É preciso sempre relembrar que ele não gostaria que sua tese de substância se igualasse à de Arnauld, pois há predicados de cunho existencial ou que dependem da vontade divina, os quais se diferenciam daqueles que integram o núcleo de proposições necessárias.

Entretanto, mesmo após essas informações, que me parecem importantes, a dificuldade principal permanece, pois é difícil aceitar uma idéia de contingência, quando se confirma que todo predicado é intrínseco a alguma noção; assim, mais uma vez: se faltar qualquer um dos predicados, não será mais a mesma substância. Se "César não atravessa o Rubicão", isso significa que é um ser que se distingue daquele que realizou a travessia. E se ele tem noção diferente, isso quer dizer que integra outro mundo, e não aquele composto pela substância que cometeu aquela ação. Logo, se tal fato não ocorresse, isso significaria que tudo seria completamente diferente e distinto. Não basta entender que a dife rença entre as modalidades de predicados se baseia no fato de uma parte depender da hipótese da criação para receber razão, ao passo que a outra apenas compõe um núcleo específico, sem que dependa de qualquer vontade para se efetivar; o mesmo parece valer para a diferenciação fundamentada em termos temporais, que indica a presença de propriedades permanentes e propriedades não-permanetes.

Existem comentadores, como Mondadori ${ }^{71}$, que entendem que a forma mais consistente de contingência, após a formulação da tese da substância individual, seria aquela apresentada anteriormente: a de possibilidade de troca de mundos. Para esse estudioso, a noção completa levaria a um superessencialismo ${ }^{72}$, pois como a falta de qualquer predicado alteraria o conceito de uma substância, isso significaria que todo predicado é essencial ao conceito da substância. Mondadori se valeu da afirmação de que

\footnotetext{
${ }^{70}$ Provavelmente as idéias de análise finita e análise infinita estão por detrás dessa afirmação. Uma substância individual não permite que sejam demonstradas as suas proposições, como ocorre no caso das figuras geométricas. Ela é muito mais complexa do que as noções gerais. Mais adiante procurarei esclarecer o que fundamenta o conceito de análise infinita; mas já é preciso estar atento que mesmo quando Leibniz fahava em dedução (um termo não muito feliz) das propriedades de uma noção completa, ele jamais se referia a uma demonstração.

${ }^{71}$ Mondadori (1994).

72 Ibidem, p. 266
} 
até os predicados contingentes são intrínsecos à noção do seu sujeito (in-esse), mesmo que não sejam absolutamente necessários. A contingência teria sentido basicamente na esfera temporal, não no interior dos conceitos. Seria contingente que tal noção encontra-se o seu exemplo efetivo no plano criado. Essa seria simplesmente uma contingência de existência $^{73}$. Sleigh Jr. prefere usar o termo supeintrinsecalness ${ }^{74}$; talvez para enfraquecer um pouco a afirmação do seu amigo ${ }^{75}$. De qualquer forma, numa primeira leitura, os textos de Leibniz parecem autorizar a tese de Mondadori.

Logo, a maneira como Leibniz defendeu a diferença entre necessidade e contingência para as substâncias não foi completamente eficaz na Correspondência? Esse não era o ponto central a ser resolvido nessas cartas, mas Leibniz teve consciência do problema e procurou solucioná-lo ainda na própria discussão com o teólogo. Na continuação da sua estratégia, ele procurou escapar ao insistir na idéia dos conceitos sub ratione generalitatis e sub ratione possibilitatis, não apenas para salvar a vontade e liberdade divina. A imaginação, segundo ele, não era tão ruim quanto pensava o seu interlocutor. Os outros "Adãos" não deveriam ser abandonados. O Adão criado possuiria um conjunto de predicados gerais que poderiam ser compartilhados por outras noções, completas e possíveis, os outros "Adãos", possíveis em si mesmos. Eles seriam versões disjuntivas de uma mesma noção geral (GP II 54). Leibniz não viu o menor problema em afirmar que esses possíveis fossem tomados a partir do que já existe; eles seriam fundamentados em proposições que estão abertas para uma suposta verdade (não autocontraditórias), o que podia abrir espaço também para a contingência. É possível falar que "César não atravessa o Rubicão" de modo que essa proposição seja tomada como possível, mesmo que seja oposta ao que ocorreu de fato, "a travessia daquele rio”. Não se deveria deixar de pensar nas versões possíveis.

Apenas a idéia de uma noção sub ratione generalitatis já seria suficiente (sim!) para criar o conceito de possíveis (em si), sem a necessidade de se conceber integralmente as idéias desses outros possíveis ${ }^{76}$. Uma noção geral, por não caracterizar um indivíduo, é compartilhada por mais de um ser, logo, é suficiente para considerar que há outras possibilidades fundadas numa noção específica. Uma noção geral é equivalente a uma

\footnotetext{
${ }^{73}$ Ibidem, p. 274. Pinheiro, pp. 76-77.

${ }_{75}^{74}$ Seleigh (1990), pp. $57-58$ e 67.

75 Ibidem, p. 68. Na sua análise da Correspondência, ele monta um forte argumento contra a posição de Mondadori para mostrar que ser uma propriedade intrínseca não é o mesmo que ser uma propriedade essencial.

${ }^{76} \ll(\ldots)$ l'Adam actuel permet de parler d'Adams possibles au sens d'Adam vague. Pour savoir ce qui est possible pour cette chose ou cet individu, on peut se contenter d'aller moins loin que l'individuation - le vague suffit» (Madouas, p.385).
} 
função, pois quando aplicada a cada mundo, resultaria numa configuração diferente dos compossíveis, ou simplesmente em um mundo distinto ${ }^{77}$.

«Lorsque Dieu produit la chose, il la produit comme un individu, et non pas comme un universel de logique, je l'avoue; mais il produit son essence avant ses accidents, sa nature avant ses opérations, suivant la priorité de leur nature, et in signo anteriore rationis» (Th 390).

Deus tem a posse dessas noções gerais, não em si mesmas, mas pelo menos na pré-criação e antes de refletir sobre suas combinações. Apesar de falar-se em antes e pré-, não se pode esquecer que isso tudo ocorre numa dimensão atemporal. A sua reflexão realiza as conexões possíveis $^{78}$. Além disso, como os mundos seriam absolutamente distintos entre si, foram exatamente as noções vagas que permitiram Leibniz postular uma comparação entre mundos, como no caso da pirâmide do mito de Sextus (Th 414).

Um conceito geral não é exatamente uma noção necessária, mas um núcleo comum entre vários indivíduos. As proposições necessárias são consideradas como aquelas que independem da existência e que valem para qualquer mundo. Já uma noção sub ratione generalitatis é incompleta, sem que abarque predicados relacionais (GP II). O que chama a atenção no "Adão", enquanto noção vaga, é que ele é definido de maneira negativa, como oposto de uma noção completa, apesar da sua proximidade com os indivíduos. Uma noção vaga pode ser entendida simplesmente como compartilhada por vários indivíduos possíveis, mas sem chegar a definir qualquer unidade substancial. São noções que atravessam todo um

\footnotetext{
${ }^{77}$ Idem, p.383.

${ }^{78}$ Vale a pena citar este longo trecho da Teodicéia (Th 225), pois ele sintetiza boa parte de tudo o que foi visto, deixando algumas coisas mais claras:

«L'infinité des possibles, quelque grande qu'elle soit, ne l'est pas plus que celle de la sagesse de Dieu, qui connaît tous les possibles. On peut même dire que si cette sagesse ne surpasse point les possibles extensivement, puisque les objets de l'entendement ne sauraient aller au-delà du possible, qui en un sens est seul inteligible, elle les surpasse intensivement, à cause des combinaisons infinement infinies qu'elle en fait, et d'autant de réflexions qu'elle fait là dessus. La sagesse de Dieu, non contente d'embrasser tous les possibles, les pénètre, les compare, les pèse les uns contre les autres, pour en estimer les degrés de perfection ou d'imperfection, le fort et le faible, le bien et le mal; elle va même au-delà des combinaisons finies, elle en fait une infinité d'infinies, c'est-à-dire une infinité des suites possibles de l'univers dont chacune contient une infinité de créatures ; et par ce moyen la sagesse divine distribue tous les possibles qu'elle avait dejà envisagés à part en autant des systèmes universels, qu'elle compare encore entre eux: et le résultat de toutes ces comparaisons et réflexions est le choix du meilleur d'entre tous ces systèmes possibles, que la sagesse fait pour satisfaire pleinement à la bonté, ce qui est justement le plan de l'univers actuel. Et toutes ces opérations de l'entendement divin, quoiqu'elles aient entre elles un ordre et une priorité de nature, se font toujours ensemble, sans qu'il y ait entre elles aucune priorité de temps ».
} 
universo de possibilidades, mas sem pertencerem exclusivamente a qualquer mundo ${ }^{79}$. Logo, os conceitos sub ratione generalitatis não portam a compossibilidade, pois se caracterizam apenas como parcelas das noções, sem que façam referência direta a qualquer mundo, visto que não dizem nada a respeito aos outros seres; as noções incompletas não têm uma relação harmônica, assim como ocorre com as substâncias ${ }^{80}$.

É possível pensar em substâncias possíveis a partir de noções vagas, que atravessam mundos e geram resultados diferentes em cada lugar em que elas participam. Uma noção sub ratione generalitatis transita por vários planos possíveis, e é inegável que certas substâncias a têm como ponto comum; contudo, a semelhança limita-se exatamente a este ponto. A partir do momento em que uma noção geral passa a integrar uma substância, após a entrada do restante das propriedades do sujeito, este passa a ser um indivíduo, completamente distinto dos outros, nos quais também entra a noção específica. Dessa forma, novamente aparece a objeção inspirada nos argumentos de Arnauld. Haveria, neste caso, substâncias completas e absolutamente distintas. Os Adãos possíveis teriam apenas nomes em comum, mas seriam indivíduos diferentes; isso seria resultado direto da noção de substância individual e, por conseguinte, do princípio da identidade os indiscerníveis. Uma noção geral não pode ser confundida com uma substância (sub ratione possibilitatis), já que esta não atravessa os vários mundos, pois se limita à composição de apenas um.

Logo, tudo leva a crer que a melhor opção para a contingência seja a contingência de existência, que parece ter o aval de Leibniz. No entanto, isso pode comprovar a impressão de nada valer dizer que "César pode fazer diferente", visto que se não fizer, é "outro César" 81 . A contingência seria apenas a troca completa de criaturas com os seus respectivos mundos? Haveria, portanto, apenas uma contingência externa, que não penetraria nas próprias criaturas? Como não pensar na necessidade do conseqüente ${ }^{82}$, mesmo após o conceito de necessidade hipotética? Tudo isso abriria margem para a contingência ser sinônimo de simples ignorância, pois tudo seria necessário, quando tomada na perspectiva das criaturas, e o que fosse considerado contingente seria originado a partir da falta de conhecimento das criaturas? Mas é preciso deixar algo claro: Leibniz

\footnotetext{
${ }^{79}$ Madouas, p.376.

${ }^{80}$ Parece que as próprias noções vagas não formam um "mundo" vago, pois um mundo poderia surgir apenas a partir da passagem sub ratione generalitatis ad individuum (GP II 54).

${ }^{81}$ Moura (2000), p.33.

${ }^{82}$ Adams (1994), p.134.
} 
defendeu a idéia de contingência da existência de determinado mundo e a contingência nas ações das criaturas (GP II 46). É óbvio que isso gera a questão mais simples: como? Nem a vontade divina e nem as noções gerais pareciam salvar as criaturas da necessidade geométrica. Qual poderia ser a solução? Talvez a mais simples: entender que aquela idéia de que o oposto é possível em si ocorre num sentido restrito, e prosseguir com o restante da sua estratégia, ou melhor, avançar ainda mais nas conseqüências geradas a partir da tese da substância individual.

Foi visto, há pouco, que a diferença entre predicados essenciais e predicados acidentais passou a representar apenas a diferença entre propriedades permanentes e propriedades que se apresentam em determinado momento. Mas independente de serem proposições que entram apenas no núcleo sub ratione generalitatis ou na noção sub ratone possibilitatis, todos têm algo em comum: eles estão em alguma noção; as noções específicas nas incompletas, e as noções possíveis nas completas. Mas mesmo que se trate de uma substância, esta não deixa de ter todos os seus predicados, apesar de que nem todos são permanentes; ne nhum deles jamais poderá estar ausente do seu conceito sem que este se torne incompleto ou mesmo alterado, formando outra substância, o que mudaria toda sua configuração original. Desta forma, faz sentido dizer que um determinado predicado (contingente) pode ser concebido como ausente, na substância, apenas na esfera temporal, mas não pode faltar ao próprio conceito desta. À primeira vista, tudo isso leva a uma conclusão chocante: mesmo as verdades de fato estão necessariamente ligadas ao conceito do sujeito ${ }^{83}$. A conexão entre o conceito do predicado com o seu sujeito não pode ser, em sentido próprio, ser classificada como contingente, mas, por enquanto, apenas a existência de determinado sujeito, detentor de todos os seus predicados. Foi visto que a vontade do criador não tem como foco a conexão entre os seres e suas propriedades, mas sim a

\footnotetext{
${ }^{83}$ Mondadori resume claramente isso de uma maneira bastante curiosa, por meio de um exemplo que se vale de um ex-presidente dos EUA e uma suposta propriedade que poderia ser-lhe atribuída:

"In other words, what is possible (from the temporal point of view) is that Nixon should cease to posses the property of not being a circus clown and that he should thereby acquire that of being $a$ circus clown. And what is not possible (from the non-temporal point of view of super-essentialism) is that Nixon should not have possessed the former and should not have acquired the latter (supposing that he in fact acquires it)" (p. 281 - grifo do autor).

Apenas na esfera temporal é que se pode fazer referência a alguma propriedade (circus clown) diversa à substância (Nixon). Isso, porém, não vale para o conceito, que pertence à dimensão atemporal. Cf. Lopes dos Santos (1998), p. $118-119$.
} 
realização de cada uma das substâncias com suas respectivas propriedades, sendo que estas se ligam à noção daquelas a priori.

Em quase todos os momentos em que Leibniz introduziu a idéia de contingência, ele simplesmente afirmava: uma verdade contingente é aquela em que a afirmação oposta permanece possível. Após a realização desse percurso, ela parece uma idéia banal e sem muita força, mas somente quando não se percebe o que está por detrás da mesma, ou melhor, o que caminha junto a ela. O conceito de substância parece impedir tal definição, visto que todos os seus predicados são essenciais ao seu conceito. Contudo, a possibilidade em si pode equilibrar o conceito de substância, desde que seja bem localizada no pensamento leibniziano.

Até este ponto, é importante manter esta idéia de que nenhuma propriedade pode estar ausente da noção de uma substância. O predicado "a travessia do Rubicão" não pode estar fora do conce ito de "César"; isso pode apenas ser concebido no tempo. Parece que apenas neste campo que se pode conceber a possibilidade em si do oposto ("a não travessia"), pois no que se refere ao conceito (na esfera atemporal) é impossível que "César não atravesse o Rubicão”. Portanto, conforme Leibniz, a contingência deveria ser encarada de uma nova maneira, assim como o conceito de liberdade.

Por sorte, assim como a substância individual, a noção de liberdade não é definida apenas logicamente, pois a lógica apenas reflete o campo metafísico. Muitos erros ocorrem quando não se tem isso em mente. Por exemplo, a liberdade não deve ser definida como pura contingência da conexão do conceito do sujeito com o seu predicado. Além disso, a contingência, no seu sentido mais geral, é apenas uma das faces, sem que traga todo o significado de ação livre. Leibniz jamais considerou que a contingência das ações significasse que elas são feitas de qualquer maneira. Os escritos de Leibniz indicam que muitos, no anseio de alcançar a idéia de liberdade, a definiam apenas através de uma idéia (ainda errônea) de contingência. Se a liberdade fosse definida apenas em termos de uma pura contingência, isso poderia gerar muitos problemas, pois ela poderia ser igualada à indiferença absoluta (C 21). Porém, para Leibniz, isso seria até mesmo pior do que considerar tudo absolutamente necessário. Era importante aceitar a contingência, mas que refletisse realmente a metafísica (a possibilidade de fazer diferente). Por outro lado, também não é a pura necessidade que expressa as ações das criaturas, mesmo que haja uma 
conexão a priori da noção da substância com todas as suas propriedades. Se houvesse apenas necessidade absoluta, todos os atos seriam inevitáveis, e a criatura não responderia por mais nada, já que tudo seria inevitável.

A maioria defende apenas uma das vias: ou há apenas necessidade absoluta dos fatos ou há uma completa indeterminação de tudo. O principal erro é considerar que a contingência ocasiona a pura indeterminação do conceito de cada substância e, consecutivamente, uma indiferença absoluta.

Mas afinal, como não defender que Leibniz prega a necessidade absoluta, se o próprio conceito de cada criatura indica que atos serão realizados? Que tipo de contingência seria possível defender após as consequiências desastrosas geradas pela defesa do conceito de substância? Ora, invocar a diferença entre noção específica e noção individual não teria, portanto, nenhuma função relevante? No que elas propõem indicar, sim. A distinção sub ratione generalitatis e sub ratione possibilitatis apenas procuram mostrar a distinção entre predicados permanentes e predicados não-permanentes, e não que alguns dos predicados estão previamente no conceito da substância e outros não. O importante é notar que as verdades de fato não se contrapõem aos predicados permanentes, absolutamente necessários. As noções gerais auxiliam a pensar nas substâncias disjuntivas (distintas), algo fundamental para se pensar os possíveis não realizados (FC 178); no entanto, elas não operam por si sós na manutenção da contingência dos atos de cada criatura.

Neste momento, parece que restaria invocar o argumento da análise infinita para recuperar as verdades de fato. Leibniz o utilizou muitas vezes, principalmente nas duas últimas décadas do séc. XVII. É fato que uma verdade razão pode ser demonstrada em número finito de passos, ou seja, pode-se alcançar uma identidade nas verdades necessárias. As proposições da geometria, p. ex. ${ }^{84}$, são demonstráveis, ao passo que uma verdade referente a qualquer fato existencial se desdobra de maneira infinita; esta tem algo análogo ao que ocorre com uma parcela das proposições matemáticas, que também se desdobra numa série infinita; p. ex., o caso dos números incomensuráveis. No entanto, a idéia de indemonstrabilidade das verdades existenciais refere-se muito mais aos aspectos do conhecimento do que exatamente uma resposta para a diferença entre a necessidade e a

${ }^{84}$ Cf. o principal exemplo utilizado por Leibniz para mostrar como se dá uma análise infinita in: FC 178 e C 19. 
contingência no pensamento leibiniziano ${ }^{85}$. A tese da análise infinita não resolve por si só esse problema, mas apenas reflete o que ocorre no próprio fundamento das substâncias.

Leibniz entendeu que a idéia de infinito entra nas coisas existentes, impossibilitando qualquer idéia de demonstrabilidade dos fatos do mundo, porque qualquer parte extraída da matéria, por menor que seja, ainda inclui infinitos seres na sua composição (FC 183-184). Todas as substâncias, portadoras de infinitos atributos, estão interligadas no interior do seu mundo; se alguém quisesse conhecer efetivamente qualquer fato, ele precisaria percorrer todas as substâncias, devido o fato de cada uma expressar todo o seu universo. Leibniz disse que, p. ex., se alguém quisesse ter certeza absoluta de que "o sol nascerá amanhã", como o criador tem, ele não teria como comprovar previamente tal fato, pois ele teria que percorrer todo o universo onde astro rei se localiza (C 18). E mesmo esse esforço não seria suficiente. Apenas a experiência pode oferecer a certeza absoluta dos fatos para os espíritos.

Mas por que seria preciso percorrer todo o universo? Isso pode causar espanto, já que sempre foi dito que nenhuma substância tem poder efetivo de ação sobre outra, ou seja, nenhuma substância é causa da ação de outra; no sentido estrito, nenhuma substância depende de qualquer outra, pois o seu conceito é auto-suficiente. Entretanto não se pode esquecer que, antes de decretar, Deus reflete sobre todos os seres que entram na formação de cada um dos mundos, sem que isto queira dizer que as substâncias tenham efeito umas sobre as outras, a não ser no campo sensível. Mas para conhecer o mundo, seria necessário seguir o mesmo percurso realizado pelo criador (refletir simultaneamente sobre todos os seres e enxergá-los em harmonia em determinados agrupamentos), algo que está muito além do poder de conhecimento das criaturas (essencialmente imperfeito). Esse mundo é fruto de uma reflexão sobre o infinito, pois há uma ponderação sobre infinitos mundos, compostos de infinitas substâncias (C 19). Em suma, seria necessário espelhar perfeitamente o entendimento de Deus para que fosse possível conhecer a priori as verdades de fato e entender porque ele quis este mundo e não outro. $\mathrm{O}$ esforço para mostrar, antes da experiência, que o "sol nascerá amanhã" exige que se entenda porque Deus optou por este plano em detrimento das infinitas possibilidades que lhe aparecem.

\footnotetext{
${ }^{85}$ Frankel, p. 292.
} 
No entanto, parece que nada é alterado no que diz respeito às criaturas, pois o princípio de in-esse permanece. Apesar de se sustentar que toda substância tem infinitos predicados, ela não escapa da tese da noção completa, ou seja, o predicado já está no conceito do sujeito. É certo que as verdades de fato não são interdependentes, pois elas não são como as proposições necessárias, que podem formar uma cadeia demonstrativa ${ }^{86}$. Mas é preciso prestar atenção nesta idéia: as verdades contingentes não estão conectadas umas às outras, mas apenas ao conceito dos seus respectivos sujeitos. Isso se dá porque, no campo metafísico, as ações são fundamentadas apenas na vontade do agente ${ }^{87}$, sem que nada o determine senão ele mesmo. Isso oferecerá o último e mais relevante para a contingência das ações das criaturas.

Sem uma compreensão da base ontológica e da base moral, a análise infinita pode ser reduzida apenas a uma impossibilidade de conhecimento. O reflexo ontológico da não interdependência das verdades de fato é que cada substância pode portar todos os seus atributos, mas ela faz tudo conforme sua natureza, sem que nada possa impedir que ela mude de direção, fora ela mesma. Nada impede a sua mudança de direção, sem que haja demonstração do futuro da criatura. Em se tratando dos seres racionais, uma ação não é determinada pela anterior, mas pela decisão do agente.

Se no âmbito do conceito, a tese da contingência de predicação não tem espaço, é porque o predicado não pertence senão ao próprio conceito. Isso significa o seguinte: toda ação é da substância, e sua noção apenas representa isso. O fundamento das verdades de fato não deverá mais ser buscado numa simples estrutura lógica, e sim na própria natureza do agente, que não é definida apenas em termos lógicos. Quando se trata deste campo, os predicados são necessariamente incluídos na noção do sujeito. Nada influencia a ligação do conceito do sujeito (substância) com o seu predicado, nem mesmo o criador. §uus, ser onipotente, não pode alterar o conceito de uma substância, porque este não está aberto a tal situação; a ligação da noção com seus predicados ocorre no âmbito do conceito, e por isso o ser onipotente apenas a identifica intelectualmente ${ }^{88}$. Deus não opta por atribuir certas propriedades à natureza de determinado ser, mas apenas identifica que essa mesma natureza tem suas respectivas propriedades. É desta forma que também deve ser entendido o fato de

\footnotetext{
${ }^{86}$ Pinheiro, pp. 78-81.

${ }_{87}$ Aqui, refiro-me aos seres racionais.

${ }^{88}$ Lopes dos Santos, pp. 118-119.
} 
Leibniz usar o termo (infeliz) dedução, pois este apenas expressa o fato do predicado estar no sujeito, quando se refere às verdades de fato, e não que haja uma conexão entre estas. Nem mesmo Deus pode demonstrar que uma verdade de fato encontra-se no conceito de determinado sujeito, pois essa modalidade de proposição é completamente distinta das verdades absolutamente necessárias. Deus apenas detecta que tal sujeito $\mathrm{S}$ possui o predicado contingente $\mathrm{P}$, sem que isso se desdobre numa demonstração. Ele é capaz de identificar que uma propriedade pertence a determinado sujeito, mas não de formar uma série de todos os predicados pertencentes a tal sujeito (C 19-20).

Em suma, em primeiro lugar, para Leibniz, a contingência tem seu lugar assegurado no plano da criação; há infinitos mundos possíveis, dos quais um é eleito com a existência. Um mundo existe a partir da hipótese da causa ou da vontade de Deus. Porém, não é tão fácil identificar a idéia de verdades contingentes no interior de um mundo. Uma substância não pode realizar o oposto do seu ato por uma ruptura do seu conceito, o que é impossível, já que ela é determinada em função de tais e tais predicados que compõem o seu conceito.

Será preciso entender melhor o que significa a vontade do agente e como ela é fundamental para entender a natureza do mesmo. Deve-se tomar consciência de que, para o autor do $D M$, nenhuma ação é realizada por uma pura necessidade, já que isto pode ser sinônimo de constrangimento, e nem por um puro acaso. Todo ato é motivado por algo que participa do conceito do agente. Contudo, é preciso sublinhar que quando se trata da natureza do agente racional a vontade é o conceito chave. A ação livre (e contingente) é fruto da vontade, a qual fundamenta a natureza do agente. Neste ponto, Leibniz invoca o exemplo da balança (GP VII 389), pois da mesma maneira que os braços descem ou sobem conforme os pesos que são colocados sobre ela, toda ação é motivada por algo. Uma escolha surge a partir dos motivos que aparecem, sem que isso indique que o agente não tira sua ação de si. É preciso entender me lhor o que significa essa analogia entre a balança e a necessidade moral ou razão suficiente da ação, da qual nem o criador escapa.

Esta etapa procurou apenas introduzir o sentido geral da contingência e alguns dos principais problemas envolvidos nesta (que não se esgotam aqui), pelo menos por uma via negativa. É insuficiente invocar uma simples idéia de contingência, já que ela pode levar à perda de muitas das teses do sistema leibniziano. A principal participação da idéia 
de contingência não se dá no campo dos conceitos (atemporal), apesar de que é importante defender a capacidade do agente poder fazer diferente, segundo Leibniz. O restante dos detalhes será visto a seguir, inclusive a questão da contingência da existência do melhor mundo, que não está tão assegurada quanto pareceu até aqui. É preciso entender isto que pode assolar o próprio criador: como sua obra pode não ser absolutamente necessária? A afirmação acerca das várias possibilidades de criação não é suficiente para qualificar a ação divina como contingente, como poderá ser visto. Será preciso entender a necessidade moral, da qual Deus é o principal defensor. Deverão ser mostrados os últimos detalhes que podem contribuir para a compreensão de como o sujeito pode fazer diferente e do significado da idéia de liberdade em Leibniz. 


\section{III}

\section{NECESSIDADE MORAL E LIBERDADE}

Da mesma forma que Leibniz quis evitar o sofisma do preguiçoso, ele também não quis que a pura indiferença imperasse sobre as ações (GP II 56). A contingência é apenas capaz de auxiliar na composição da noção de liberdade, de uma maneira bastante específica, mas não de exprimi-la completamente. Haveria um grande problema se ser livre fosse apenas agir de modo contingente, pois poderia significar que o próprio acaso orienta $\mathrm{o}$ agente. O asno de Buridano é tomado como caso exemplar de indiferença absoluta, visto que esse animal, sem poder decidir-se para qual dos lados devia buscar seu alimento, acabou por morrer de inanição (GP III 168 e VII 111). Agir livremente não é agir de qualquer maneira. Não se pode esquecer que a liberdade não está apartada da predeterminação. É preciso, então, entender o que está envolvido nesta idéia: tudo está predeterminado e o agente coopera com isso. Eis o retorno daquelas duas idéias centrais: todo o ser possui a totalidade das suas propriedades e Deus conhece tudo a priori.

Muitos costumam entender que um ato deve ser considerado livre enquanto não houver qualquer determinação, pois a ação deve partir absolutamente do agente, e se houvesse algo além, a ação poderia ser considerada como oriunda de uma compulsão externa. Nada deveria prender a atenção do agente na encruzilhada em que ele se encontra, e seria isto que o tornaria livre: ir para A ou para B sem qualquer motivo ${ }^{89}$. Nenhum objeto poderia ter qualquer influência sobre a decisão do agente num ato livre. "É aí que eles se enganam”, afirmava Leibniz (Th 35), pois se alguém agisse pelo simples motivo de agir, ele teria o nada como fonte dos seus atos (Th 320), logo, não deveria responder por mais nada, já que seria indiferente realizar $\mathrm{A}$ ou $\mathrm{B}^{90}$. Felizmente, as coisas não acontecem assim, a começar pela própria origem do mundo. Essa idéia de agir determinado por algo deverá ser bem entendida, pois Leibniz também não considerou que uma ação é simplesmente determinada por um objeto, o que poderia indicar que, no seu pensamento, todo ato é fruto

\footnotetext{
${ }^{89} \mathrm{O}$ combate a essa idéia é o eixo da crítica de Leibniz dirigida ao livro de W. King (Cf. Thk).

${ }^{90} \mathrm{O}$ artigo de Moura (2004) trata desse assunto desde suas primeiras páginas.
} 
de uma compulsão externa. Leibniz também estava longe de pensar isso, pois a sua idéia de liberdade tem a vontade do agente (racional) como o foco.

Ora, dizia Leibniz, por mais difícil que seja aceitar esta idéia, as ações são necessárias, não conforme uma necessidade geométrica, mas conforme a natureza do agente e por uma necessidade moral, já que fazer de outra maneira sempre será possível em si, mesmo que isso não se refira ao seu próprio conceito. Para começar (e retomar): todo ser age por uma razão suficiente ou necessidade moral. Se a razão não estiver integralmente na própria substância, como ocorre em Deus, está na própria origem do mundo. Deus tem a própria razão da sua existência e ainda fornece a razão da existência de determinadas criaturas, com suas respectivas propriedades.

Não há ninguém melhor do que o criador para oferecer melhores detalhes sobre este ponto. Há necessidade de arrematar tudo o que foi dito sobre o criador até aqui para que, assim, seja comprovado como se dão as ações e, finalmente, o que Leibniz entende por liberdade; sem tal explicação, também há o risco de tudo desmoronar-se, sem que se possa falar em qualquer tipo de ação moral.

Foram apresentados muitos detalhes sobre a natureza divina e de como Deus opera (Deus arquiteto). Ele enxerga o melhor e opta por criá-lo. De início, é preciso responder à questão (deixada em aberto) que pode excluir a idéia de contingência por completo: Deus poderia fazer diferente sem prejudicar a sua qualidade de ser perfeito? Aparentemente, ele seria obrigado a fazer o que ele identifica como o melhor; como ser onipotente, ele deve efetivá-lo. Por um lado, é verdade que ele é obrigado a decretar o que é identificado como ótimo, mas se tal afirmação não for bem entendida, isso pode criar um efeito contrário, pois pode indicar que Deus não é livre, que ele apenas opera de maneira imediata e volta-se à estaca zero: o império da fatalidade e a inutilidade dos possíveis. Eis o retorno do terceiro atributo (principal) do criador: a bondade (GP VI 441). Esta se distingue da onisciência e da onipotência, visto que ela revela-se apenas a partir da ação divina; para que Deus seja visto como infinitamente bom, ele precisa ter sua vontade direcionada para o melhor objeto.

Não foi difícil considerar, num primeiro momento, que as opções de criação são possíveis em si. Por outro lado, Deus deve existir em função de suas perfeições, que formam a base da sua existência necessária. Nesse conjunto de perfeições entra aquela 
referente à moral, ou seja, Deus deve agir da maneira que melhor lhe convém. Não há dúvida que é difícil defender que ele não age de maneira absolutamente necessária, ao contrário do que foi visto acima. Eis que surge um problema ainda mais forte quando se defende que Deus existe necessariamente, sem que deva agir de maneira absolutamente necessária ${ }^{91}$. Tudo leva a crer que sua criação é totalmente necessária.

Como sair desse impasse? Segundo Leibniz, não é tão complicado, visto que Deus é inclinado, porque quer o melhor, mas não é constrangido a agir do melhor modo. Pôde-se ver que o mundo não surgiu como ocorria no espinosismo, pois Leibniz não via a criação como originada da pura necessidade da natureza divina, como fora sustentado pelo outro filósofo.

«(...)Spinoza cherchait-il une nécessité de sa métaphysique dans les événements, il ne croiait pas que Dieu fût determiné par sa bonté et par sa perfection (que cet auteur traitait de chimè res par rapport à l'univers), mais par la nécessité de sa nature: comme le demi-cercle est obligé de ne comprendre que les angles droits, sans en avoir la conaissance, ni la volonté » (Th 174).

No geral, a criação do mundo mais harmônico pode e deve ser caracterizada como contingente. Sem dúvida, é difícil entender como há uma espécie de obrigação (inclinação), mas não uma pura necessidade das ações divinas, devido às várias maneiras como Leibniz afirma tal coisa ${ }^{92}$.

Mas afinal, como a contingência, que parecia assegurada no capítulo anterior, poderia entrar na esfera da criação sem que Deus prejudicasse sua imagem? As várias possibilidades se apresentam perante o criador e este escolhe certamente uma dentre elas. Desde já, o principal detalhe a ser guardado é: toda ação exige que haja um bem a ser perseguido; no caso do criador, o melhor será o seu objeto. Entretanto, ele não é obrigado a escolher apenas porque conhece e porque pode, mas também por que quer.

\footnotetext{
${ }_{91}$ Russel, p. 39; Rescher (1952), pp. 32-36.

92 O principal ponto da discussão dos estudiosos acerca desse assunto é sber onde está o centro da contingência quando se trata do decreto divino. Ele estaria nas várias possibilidades, no próprio querer divino ou mesmo no fato de que aquilo que é considerado o melhor mundo pode não passar de uma afirmação contingente? Esta última idéia foi indicada por Adams (1994, pp. 141-143), mas não parece ser das melhores, mesmo que ele invoque a noção de análise infinita, que foi vista acima. Não se pode esquecer que a armação dos mundos tem alto grau de objetividade, e isso parece exigir que o melhor apareça necessariamente ao intelecto divino (Frankel, pp. 290-291). Dizer que o melhor mundo é armado de modo contingente pode abrir margem para um puro voluntarismo.
} 
Leibniz deixou esta estrutura clara na Teodicéia. Ele usou o exemplo do caminho entre dois pontos (Th 234). Há várias maneiras de realizar o trajeto entre ambos, mas a reta é o melhor, por ser o mais curto. Todavia, se ela é a opção mais adequada, ela não torna os outros caminhos impossíveis, mesmo que sejam literalmente tortuosos. Quando se diz que Deus escolheu o mundo mais harmonioso, seria como se tivesse escolhido a reta, sem que tivesse tornado os outros mundos impossíveis (em si). Eles poderiam entrar no lugar daquele, mas não foi algo conveniente. Ele fez isso conforme sua natureza de ser perfeito ou de maneira moralmente necessária, mas num campo de possibilidades. Do ponto de vista metafísico, sempre foi contingente que Deus criasse tal mundo, mas sempre foi moralmente necessário que ele fizesse o que fez. Deus criou o melhor porque é inclinado a escolher algo e porque o seu objetivo é realizar tal obra. A natureza divina indica que ele agiria dessa forma.

«Dieu a choisi entre différents partis tous possibles ; ainsi, méthaphysiquement parlant, il pouvait choisir ou faire ce qui ne fût point le meilleur ; mais il ne le pouvait point moralment parlant» (Th 234).

Há coisas que foram recusadas, que jamais virão a existir, e que permanecem possíveis por acidente. $\mathrm{O}$ fato de Deus não querer não significa que são impossíveis; não se pode esquecer que o critério de possibilidade é autônomo, sem que dependa diretamente da vontade divina, que se limita a escolher. Leibniz deixou clara sua posição contra os que negavam a possibilidade de tudo o que não foi criado. Caso seja logicamente concebível, tudo aquilo que não existe poderia existir, mas apenas por acidente (Conf. 56-57). Por isso a afirmação daquela forma de contingência, possibilidade do oposto, não foi de pouca validade para o que Leibniz propôs explicar.

Deus tem máxima inteligência, ou seja, tem um conhecimento distinto de tudo. Ele age por si, sem que nada de exterior interfira na sua ação; os seus objetos não fornecem o tom final para sua ação, mas tudo ocorre a partir da sua decisão. Isso sintetiza o significado do agir perfeitamente pela própria natureza, no caso de Deus. 
No primeiro capítulo, foi demonstrado que as criaturas agem por si; de agora em diante, é preciso entender ainda mais sobre sua s naturezas e notar como estas imitam imperfeitamente a natureza do criador.

Deus conhece cada ser porque cada um tem uma natureza que se apresenta integralmente ao seu intelecto. Assim, o futuro detectado pelo criador apenas representa aquilo que a criatura irá fazer por si mesma. Como já parece visível, este é o ponto central para começar a entender a idéia de liberdade para Leibniz: toda criatura tem suas ações no seu conceito, de maneira livre e contingente. Essa é idéia que norteia o capítulo anterior junto a este. No seu quinto escrito a Clarke, Leibniz resumiu isso da seguinte maneira:

"Mas nem essa presciência nem essa preordenação atentam contra a liberdade. De fato, Deus, levado pela suprema razão a fazer a escolha, entre muitas seqüências de coisas ou mundos possíveis, daquele em que criaturas livres tomassem tais ou tais resoluções, ainda que não sem seu concurso, tornou assim todo acontecimento certo e determinado de uma vez por todas, sem derrogar com isso a liberdade das criaturas, pois esse simples decreto da escolha não muda, mas apenas atualiza as suas naturezas, vistas por ele em suas idéias" (GP VII 390/ LP I 194 - grifo meu).

Toda criatura também se dirige para um bem, ou seja, toda ação ocorre em função de um objeto detectado e almejado. No caso das criaturas racionais, elas têm o poder de deliberar sobre o seu futuro, se assemelhando ao criador. Os homens não apenas agem em função do que lhes surge como um bem, como também escolhem os seus objetos. Eles podem mudar de opinião acerca de uma escolha (C 20-21); que eles façam isso ou não, já é outra história.

As criaturas espelham o mundo, já os espíritos refletem o criador. As substâncias simples têm a espontaneidade como o principal elemento das suas naturezas. Elas também agem em função de um objeto, mas por uma perseguição simples do seu fim (GP VI 600). Foi dito que os animais distinguem-se das simples substâncias - eles têm memória -, mas não possuem o ingrediente que aproxima os homens de Deus: o entendimento (GP VI 600-601). Isso permite que estes reflitam sobre os objetos e, assim, possam adequá-los às suas escolhas.

Deus segue o que é o melhor; no caso do restante das criaturas, elas seguem o que lhes parece melhor. Assim como os pesos fazem com que desça um dos braços da balança, é um bem que faz com que haja a opção por uma determinada ação (GP VII 389 e 392). O fato de uma substância agir conforme o que lhe surge como um bem expressa uma 
espécie de necessidade. Mesmo que os motivos não sejam perceptíveis, por envolverem um número infinito de coisas, ninguém deve duvidar que estejam sempre presentes (Conf. 7071) e indicados no conceito de cada substância.

No caso das substâncias simples, para usar uma expressão de Frankel, elas são ontologicamente responsáveis pelos conceitos das suas naturezas. O homem, ser semelhante ao criador, também é moralmente responsável pela sua natureza ${ }^{93}$, ou melhor, suas ações deliberadas entram na composição do seu conceito ${ }^{94}$, devido a participação do seu intelecto. Suas escolhas lhe são intrínsecas. Essa semelhança entre criador e espíritos deve ser bem entendida, pois também há aquela forma de necessidade (moral) no caso das criaturas racionais. Como afirmou Leibniz, eles são inclinados em todas as ações. É preciso explicar um pouco do mecanismo da escolha dos homens.

As criaturas possuem suas percepções e representações ${ }^{95}$. Nos espíritos, o entendimento processa a representação de um objeto para o agente fulgamento que proporciona bens em vários níveis de adequação) e orienta este na direção daquele.

Boa parte dos que defendem a absoluta indiferença como definição da liberdade entende que se um objeto tiver algum papel na ação do agente, este corre o risco de ser constrangido por algo exterior. Ora - diria Leibniz -, o objeto exterior tem grande importância para o agente, sem que também seja suficiente para gerar a escolha (GP VII 455). Ele é apenas um motivo para a vontade.

«(...)une chose active peut recevoir de dehors quelque détermination ou direction
capable de changer celle qu'elle aurait d'elle-même. Enfin, lors même qu'une
substance active n'est déterminée que par elle-même, il ne s'ensuit point qu'elle ne soit
point mue par les objets; car c'est la représentation de l'objet qui est en elle-même, qui
contribue à la détermination; laquele ainsi ne vient poin de dehors, et, par conséquant,
la spontaneité y est tout entière. Les objets n'agissent point sur les substances
intelligentes comme causes efficientes et physiques, mais come causes finales et
morales » (Thk 20).

\footnotetext{
${ }^{93}$ Frankel, p. 297:

"Ontological responsability, in the sense that a stone is ontologically responsible for its heaviness, because that is part of its complete concept, is necessary but not sufficient for moral responsibility. In order to be morally responsible an individual must not only be ontologically responsible - the source of the action - but also must be intelligent and must actively will the action".

${ }^{94}$ Idem, pp. 287, 298-300.

${ }^{95}$ Cf. supra p. 48.
} 
Não é o objeto que move, mas o agente que se move a partir da identificação de um objeto, aceitando este ou não. No sentido metafísico, todos agem apenas em função de si. Uma substância age apenas em função da representação de um bem, pois as percepções permitem que algo lhe apareça; mas todo esse processo é interno à mônada, onde o exterior se apresenta como uma espécie de eco (GP VI 599; Mon 25).

Mesmo como uma das principais peças das ações, Leibniz observou que a vontade não opera sozinha, mas é auxiliada pelo entendime nto nas escolhas. Ele ilumina a vontade. O intelecto está sempre presente na representação do bem, mas não de um único modo. $\mathrm{O}$ entendimento pode ter o seu papel reduzido a níveis quase ínfimos, que acaba por gerar a impressão da sua total ausência nas escolhas. Quando não funciona da melhor maneira, principalmente devido às imperfeições do agente, o entendimento não oferece o objeto determinante da vontade, e ocorre o domínio das simples aparências. Mas o entendimento sempre terá o seu papel na representação do bem desejado, mesmo que este não seja um bem adequado. A vontade oferece o aval final acerca da representação do objeto, sem que seja o único ingrediente da realização do ato. A vontade não atribui peso ao objeto, mas ele surge com determinado peso perante ela após ter passado pelo entendimento.

« Supposé que par mon choix, qui fait que e donne à lóbjet choisi six degré de bonté, et qu'il y eût auparavant deux degrés de mal dans mon état: je deviendrai hereux tout d'un coup et à mon aise ; car j'aurais quatre dégrés de revenant bon, ou de bien franc. Voilà qui est beau, sans doute ; mais, par malheur, il est impossible. Car que moyen de donner ces six degrés de bonté à l'objet ? Il nous faudrait pour cela la puissance de changer notre goût ou les choses comme bon nous semble. Ce serait à peu près comme si je pouvais dire efficacement au plomb : Tu seras or ; au caillou : Tu seras diamant ; ou du moins : Vous me ferez le même effet » (Thk 18).

Torna-se ainda mais visível porque Leibniz criticou aqueles que queriam um império absoluto da vontade pelo fato de que se tudo fosse tributário dessa, haveria o risco do reaparecimento do problema da indiferença absoluta. A ação tem início com após a identificação de um certo objeto que pode fazer com que o agente se dirija ao mesmo. Tudo isso, somado à autodeterminação, faz com que o ato seja efetivado. Quando o objeto é convertido num bem, Leibniz afirma não restar dúvida de que se partirá imediatamente na direção daquele, principalmente se não houver obstáculos. 
É importante, desde já, entender que o objeto da vontade não é simples fruto da vontade. Leibniz sempre procurou mostrar que ninguém deseja querer algo, já que isso inviabilizaria a ocorrência de algum princípio para a ação e, assim, seria um processo infinito de quereres. A vontade nunca está vazia de conteúdo. O objeto da vontade é originado no processo de representação do mesmo e funciona como ponto de partida para a escolha realizada pelo agente. Afinal, a vontade não passa do deleite em relação à existência de algo que lhe é oferecido e passível de aceitação (Conf. 66-67); a vontade é fundamental para o homem, mas sem que tenha um poder absoluto de decisão e de intelecção sobre aquilo que é almejado. O sujeito é dotado de apetites (Thk 910), e æe deleita com os fatos que ocorrem diante dos seus olhos (identificação), sem que crie o seu bem por si mesmo.

«(...) bien qu'il soit en notre pouvoir de faire ce que nous voulons, il n'est pas en notre pouvoir de vouloir ce que nous voulons, mais ce que nous sentons agréable ou nous jugeons être bon. Or juger ou ne pas juger bon quelque chose n'est pas en notre pouvoir, persone pas même en s'y échinant, qu'il le veuille ou non, ne ferait sans raisons que ce qu'il croit, il ne croie pas. Puisque donc la croyance n'est pas au pouvoir de la volonté, la volonté non plus n'est pas au pouvoir de la volonté. Et mettez que nous voulions parce que nous voulons : porquoi voulons-nous vouloir ? est-ce, derechef, en vertu d'une autre volonté, ou en vertu de rien, c'est-à-dire sans raisons?» (Conf. 67$69)^{96}$.

A própria vontade não é objeto de querer, pois ninguém quer ter vontade, mas tem vontade de algo, de um bem, pois se não fosse desta maneira isso poderia ir ao infinito. Mesmo Deus não se vale desse poder quimérico, pois ele não tem o poder de determinar voluntariamente o que ele quer, mas sim a partir do que lhe aparece no seu entendimento, que é convertido no seu bem.

\footnotetext{
${ }^{96}$ Esta outra passagem oferece mais explicações (Thk 16):

«Si la Volonté doit juger, ou prendre connoissance des raisons et des inclinations que l'entendement ou les sens luy present, il luy faudra un autre entendement dans elle même, pour entendre ce qu'on luy present. La verité est, que l'Ame, ou la Substance qui pense entend les raisons, et sent les inclinations, et se determine selon la prevalence des representations qui modifient sa force active, pour especifier l'action».
} 
Mas e o caso daqueles que defendem a possibilidade de fazer algo que vá de encontro ao que é identificado como o legítimo bem, a ponto mesmo de considerarem este o melhor símbolo para a liberdade, ao invés de seguir a razão ou aquilo que lhes parece melhor? Leibniz entendeu que isso seria uma grande ilusão. Neste caso, a obstinação seria superior ao que eles consideram ser "um bem", e eles acabam por gerar uma inversão: "agir contra o "melhor"” transforma-se na razão da ação. Leibniz ilustra isso com o seu comentário do famoso verso de Ovídio:

"Video meliora proboque, deteriora sequor"

Ora, para Leibniz, essa passagem sofre de uma má interpretação, tornando-a o símbolo da liberdade quimérica. Para ele, ela apenas ilustra a inversão realizada pela personagem, Medéia, que acredita ter substituído um verdadeiro bem por uma escolha infame. O que ocorre realmente é a troca de um bem, que poderia realmente ser a melhor opção, por um motivo considerado mais forte pelo agente. Por um defeito das disposições do agente, ele procura algo inferior, seja um desejo excessivo ou qualquer coisa que pode prejudicátlo no futuro. Por fim, ele não deixa de procurar um bem e, como foi visto, geralmente é um bem apenas em aparência, apesar de não deixar de ser a finalidade da ação.

Um julgamento adequado não é simplesmente abandonado, mas antes pode ser substituído por uma impressão mais forte. Mesmo uma ação vergonhosa também é fundamentada por uma razão, um motivo. Sempre haverá algo desejado na base da ação (deleite pela existência de algo). Os motivos não estão exatamente no poder da vontade, mas é de sua alçada aceitá-los ou não como objetos do ato. Nada será feito sem que algum deles seja tomado como fim e, assim, se algum motivo é abandonado, é porque aparece uma razão mais forte para o agente, independente do verdadeiro valor do objeto. Apenas um desejo substitui outro desejo ${ }^{98}$. Uma opção pode ser abandonada desde que substituída por outra ainda mais forte: um novo bem. No caso de Medéia, Leibniz entendia que o discurso proferido pela personagem apenas ilustrava a dissimulação de um auto-engano.

\footnotetext{
97 "Vejo o melhor, aprovo-o, mas faço o pior" (Metamorfoses, VII, 20).

98 Aqui uso essa palavra no sentido geral, pois vale tanto para os desejos naturais, os apetites, quanto para aqueles que são filtrados pela razão, como poderá ser visto.
} 
Não é razoável pensar que agir livremente seja escolher o oposto daquilo que é reconhecido como melhor. Mesmo que alguém pense que pode escolher algo supostamente contrário ao que lhe parece melhor - e realmente pode -, o que ele faz é apenas seguir uma razão mais forte; neste caso, seria o próprio ato de contrariar. O agente tem poder para não realizar o ato, mas não é este o principal símbolo da liberdade (DM XXX).

A liberdade não tem um aspecto irracional na sua base, ela não é fruto de um capricho, pensou Leibniz. É impossível que os dois lados da escolha tenham o mesmo valor como pesos iguais nos dois lados da balança, tanto pelo lado do objeto, como do agente (Th 35). Logo que algo surge como a melhor opção, não se pode duvidar que seja o objeto a ser perseguido, como já está indicado na natureza do agente.

Até aqui, foi completado o quadro da necessidade moral ou hipotética, que sempre envolve uma vontade. No caso da totalidade do mundo, ela envolve a vontade divina, que permite dizer que é orientada pelo princípio do melhor ${ }^{99}$. Mas tudo indica que esse princípio é subalterno ao próprio PRS. Deus, dotado de máxima bondade, se dirige ao que lhe surge como a obra mais adequada. No caso dos espíritos, eles também se dirigem para o que consideram melhor; sempre há uma razão suficiente para os seus atos, fundamentada nas suas vontades. Isso não significa que eles perseguem necessariamente o legítimo bem, mas não deixam de buscar aquilo que suas naturezas indicam, e que é previsto pelo criador.

"Deus, concorrendo ordinariamente para as nossas ações, apenas segue as leis que estabeleceu, isto é, conserva e produz continuamente o nosso ser de forma que nossos pensamentos nos chegam espontânea e livremente, segundo a ordem implícita da noção da nossa substância individual, na qual se podiam prever desde toda eternidade. Ademais, em virtude do decreto por ele estabelecido da vontade tender sempre para o bem aparente, exprimindo ou imitando a vontade de Deus sob certos aspectos particulares, relativamente aos quais esse bem aparente tem sempre algo de verdadeiro, determina a nossa para a escolha do que parece melhor, sem, contudo, a necessitar. Porque, falando de modo absoluto, a vontade está na indiferença, desde que se oponha à necessidade, e tem o poder de proceder diversamente ou ainda de suspender de todo a sua ação, pois ambos os partidos são e continuam possíveis" (DM XXX).

${ }^{99}$ Rescher (1952), pp. 29-32. 
A tese da ação conforme a natureza não se contrapõe à noção de contingência; pelo contrário, pois ela é assegurada por esta. Leib niz dizia que era certo que nenhuma criatura usaria esse poder de fazer diferente, mas essa capacidade nunca está apartada do horizonte da criatura (DM XXX), e isso era suficiente para os seus propósitos de manutenção da contingência ${ }^{100}$. A ação da criatura racional é contingente, assim como a própria criação de determinado mundo, mas ambas são frutos de uma necessidade moral ou de uma razão suficiente. E, como foi visto, as ações de uma substância constituem o seu conceito; elas podem ser realizadas livremente, conforme a vontade do agente, mas já integram previamente a noção deste ${ }^{101}$. O conceito de uma substância racional indica que ela escolherá o que lhe parece melhor, de maneira voluntária e contingente, pois ela não é determinada senão por sua natureza ${ }^{102}$; em outras palavras, as ações são fundamentadas apenas na vontade do agente, sem que nada o determine senão ele mesmo.

A determinação fundamentada no bem não representa uma necessidade absoluta. Além de ser escolhido em função de um fim, o mundo é totalmente ordenado a partir da idéia de finalidade da ação das criaturas, e é possível elaborar leis subalternas para muitos dos fatos por meio de um processo indutivo, devido o alto grau de determinação da ação. Mesmo as substâncias simples agem conforme um fim; no caso destas, a finalidade é, em muitos casos, facilmente detectada. Que o "sol vá nascer amanhã" ou que "essa pedra irá cair em tal ponto ao ser lançada" (C 18-19) são casos que podem ser razoavelmente previstos a partir do que está envolvido em tais fatos, apesar de serem indemonstráveis. Os seres não racionais são ontologicamente responsáveis pelas suas naturezas; eles perseguem seus fins, sem o mesmo grau de autonomia dos espíritos, e permitem uma maneira de exprimir os seus movimentos. É mais simples prever os seus movimentos, já que eles espelham principalmente o mundo e não o criador ${ }^{103}$.

\footnotetext{
${ }^{100}$ Frankel, pp.293 e 298-300.

${ }^{101}$ Frankel, p. 287.

102 Lopes dos Santos (1999), pp. 394 -396.

103 Isso retoma a relação harmônica das causas finais com as causas eficientes. No plano dos fenômenos, é possível formular leis que expressem as ações das substâncias simples. As leis físicas também dependem da vontade divina em escolher determinado mundo - são necessidades hipotéticas - e estão sob a orientação das naturezas dos agentes (DM XVI). Apesar de que as leis físicas podem ser quebradas por meio dos milagres, pois não deixam de ser contingentes; são leis apenas subalternas (particulares) à lei geral que rege o mundo ou máxima razão, a qual jamais é quebrada, pois é ela que sintetiza toda a beleza da obra divina (C 19). O "sol
} 
Os espíritos assemelham-se ao criador de maneira imperfeita, o que inviabiliza qualquer certeza acerca do bem que irão buscar. Leibniz afirma que eles caracterizam uma espécie de milagre privado (C 20), pois há uma grande flutuação nas suas escolhas. As ações humanas não permitem um grau tão exato nas suas previsões. Eles se assemelham ao criador mais em função do modelo de ação do que com relação à finalidade propria mente dita. O objeto de Deus é identificável, ao contrário dos objetos dos homens. Por mais surpreendente que possa parecer, a ação de Deus tem uma natureza moralmente determinada (C 21), que o aproxima de uma necessidade de ordem física ${ }^{104}$, sem que isso signifique que ele seja coagido ou por lhe faltar a capacidade de escolher: é certo que ele agirá da melhor maneira. O seu bem lhe atrai de tal forma que sua ação (moral) se assemelha à previsão do "lançamento da pedra". Ele não faz diferente, mesmo que ele possa. Deus não quer e faz senão o melhor. A confusão acerca do bem ocorre, sobretudo, nas cabeças dos homens, visto que se fossem racional e moralmente perfeitos, estariam muito próximos do criador, como ocorre no caso dos anjos (C 21). Todavia, não se deve menosprezar a necessidade moral não se distancia completamente dos espíritos, o que pode oferecer um maior grau de determinação também nas suas ações; eles sempre procuram seus bens aparentes. No entanto, enquanto estão presos apenas às simples aparências das coisas, dificilmente é perceptível o que eles farão; a não ser que se tornem mais esclarecidos acerca dos seus objetos, o que pode permitir uma previsão daquilo que determinado espírito fará. Em tal caso (de esclarecimento) eles não apenas perseguem seus bens, como também perseguem aquilo que se aproxima do objeto divino.

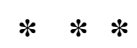

As criaturas podem ser consideradas livres na medida em que podem agir por si mesmas e em direção de um bem, de maneira contingente. Entretanto, ao contrário de Deus, elas normalmente perseguem um bem aparente. A natureza divina impede que ele deixe de

pode não nascer amanha", quebrando uma regra indutiva, mas sem que isso signifique que as leis gerais do mundo tenham sido feridas.

${ }^{104}$ Natureza e física são dois termos que têm bastante afinidade. Basta lembrar que eles têm uma raiz comum, a palavra físis (Adams, 2005, p. 186). 
buscar o melhor, segundo a idéia central de liberdade (Th 110). Deus é o ser mais livre não simplesmente por possuir uma vontade independente de qualquer determinação, mas por se ligar àquilo que lhe dará o caráter de bom. Foi importante mostrar que, segundo Leibniz, a liberdade não é sustentada apenas pela simples possibilidade da escolha da posição contrária, mas antes por um aspecto intelectual, o reconhecimento racional do objeto e a opção pelo mesmo.

Contudo, por que os homens imitam o criador de maneira imperfeita? Para compreender melhor essas falhas das criaturas racionais e porque elas não são totalmente livres, é necessário retomar novamente aquela característica vista acima: elas sofrem de uma limitação essencial ${ }^{105}$ (Gr 364-365; GP VI 449-450). O criador é responsável somente pelo que há de positivo na sua obra (C 22 e 24; Gr 363-364; GP VI 448-450), tanto na perspectiva metafísica quanto moral, tanto no todo quanto nas partes. Ele quer apenas o que há de bom, seja a totalidade, seja o que há de bom no interior da sua obra. Ele quer o melhor no todo, não os defeitos localizados nas partes; assim, ele não é causa imediata das falhas que se integram no mundo e nem quer esses defeitos. Deus enxerga e cria um plano repleto de criaturas, que apenas exprimem o todo de maneira particular - são apenas pontos de vista. Isso possibilita entrada das imperfeições (Gr 306). Apenas Deus é totalmente perfeito; a perfeição não pode ser transmitida integralmente para o criado, já que poderia abrir espaço para mais de um Deus, o que traria contradição no sistema. Deus é único (Conf. 44-47).

Como cada criatura tem uma natureza essencialmente imperfeita, isso permite a aparição de duas principais modalidades de mal. Há imperfeições ou limites possuídos por uma criatura que não dependem exatamente da maneira como ela se comporta; fazem parte deste tipo de mal, p. ex., as dores e os incômodos em geral. Tudo o que há de ruim e que a criatura depara-se, sem que ela tenha influência direta, forma o que Leibniz denominava como mal físico.

Há ainda outra forma de imperfeição, a saber, a imperfeição moral. Este tipo de mal, ao contrário dos outros, não participa do conceito de todos os seres, mas apenas daqueles dotados de razão, que é o caso dos homens. O mal moral também pode ser chamado de pecado ou mal de culpa (GP VI 444).

\footnotetext{
${ }^{105}$ Cf. supra p. 26.
} 
« Dieu fournit toutes les conditions du péché, sauf la volonté, et par conséquent il ne pèche pas. Je pense donc que les péchés sont imputables non à la volonté mais à l'entedement divin, ou ce qui revien au même, aux fameuses idées éternelles, c'est-àdire à la nature des choses, afin qu'on n'aille pas imaginer qu'il y a deux principes des choses, des juemaux ennemis, un pour le bien, l'autre pour le mal »(Conf. 42-43 - grifo meu).

O mal de culpa pode gerar mal físico, pois as criaturas, a partir de suas ações, podem prejudicar-se de tal forma que acabam por trazer consequiências que já não estão mais sobre os seus controles. As próprias dores exemplificam tal fato, além das punições que elas terão que arcar futuramente ${ }^{106}$.

Deus age da melhor maneira, ou seja, o seu ato é moralmente perfeito e contingente, sem que participe diretamente de qualquer uma das modalidades de imperfeição das criaturas (Gr 368). O criador mantém-se à parte das imperfeições e maldades, visíveis na esfera do particular. Como foi visto desde o início, ele permite os males porque o mundo mais elaborado contém imperfeições em meio às partes, não enquanto todo.

Tendo em vista a explicação do mal de culpa, Leibniz tomou uma déia inspirada em Kepler, a saber: a inércia natural das criaturas. Numa situação de movimento, o retardamento deste é atribuído ao corpo, e não à própria força que gera o deslocamento. Isso fica claro quando Leibniz toma o exemplo do "rio e do barco". O rio oferece a mesma velocidade de deslocamento para todas as embarcações, mas a variação de velocidade destas depende da quantidade de carga transportada. Assim como a carga refere-se ao barco, a criatura é responsável pelos seus atos e pelos efeitos destes. Leibniz defendeu que Deus não foi injusto no momento de oferecer as oportunidades para todos, pois ele, como ser bom, sempre amou todas de maneira equilibrada. O restante dos problemas que invadem a vida das criaturas compete a elas mesmas.

Os homens podem dizer que Deus é o único responsável pelo que fazem. Porém, ele não interfere nos atos que eles mesmos escolhem e pelos quais eles mesmos respondem. O criador apenas permite que eles cumpram aquilo que está nas suas naturezas,

\footnotetext{
${ }^{106}$ Belaval deixa claro esta outra forma de manifestação do mal físico (1962, pp. 269-270):

«A son tour, le mal physique, «c'est-à-dire, les souffrances, les misères » (Th 241), est une conséquence du mal moral: ce qui signifie que le mal physique peut être considére à la fois comme conséquence physique de la limitation originelle, et comme conséquence éthique, punition du péché ».
} 
que incluem as más ações. Esses atos integram o melhor mundo, que Deus se vê na obrigação de criar, sem que ele queira o mal em si (Thc 38). Para que ele mesmo não caísse em imperfeição, Deus precisou fazer tal mundo, que abarca o mal nas suas partes (Gr 449).

Outra reclamação combatida por Leibniz foi a daqueles que culpavam Deus por não tê-los criado de outra maneira, com melhor disposição e sem que pecassem ${ }^{107}$. Entretanto, isso levantava dois grandes problemas: eles seriam outros seres e poderia ser dito que as vontades das criaturas apenas escondem o que elas realmente são: a vontade de Deus. Tudo o que foi visto acima mostrou como Leibniz tentou armar uma idéia de natureza que fosse própria à criatura. Ele bus cou oferecer um alto grau de autonomia para cada uma, exceto no que dizia respeito à existência. Tal processo resultou naquelas implicações, vistas na primeira parte: o princípio de máxima distinção, a espontaneidade, a idéia de liberdade da criatura etc. Esta outra queixa poderia revogar todas as características conquistadas pelo sistema. A vontade da criatura deve destacar-se da vontade divina. Ele apenas permite que ela seja exercida da maneira como a criatura considera mais conveniente.

Muitos reclamavam das coisas como se o destino dominasse a vida das criaturas, sem que eles tivessem qualquer poder de ação. Leibniz mostrou que a razão do preguiçoso não deveria encontrar lugar no seu sistema. Nem mesmo o destino estóico deveria ser o modelo a ser seguido. O fatum stoicum deveria ser afastado (GP VI 30), visto que Leibniz entendeu que não bastava esperar pacientemente a obra de um destino absolutamente necessário, pois deveria ser possível e necessário agir do modo como se quer e a partir daquilo que se deseja.

Mas mesmo após todos os argumentos que foram apresentados, ainda havia aqueles que insistiam no problema da predeterminação e da previsão divina. Leibniz ofereceu uma reposta curiosa (e até mesmo astuta) para os que persistiam na defesa da impossibilidade da liberdade das ações. Boa parte das queixa apareciam por não se notar como as ações partem do próprio agente, pois eles não enxergavam a distinção entre as razões, uma da totalidade e uma outra da ação, e como uma leva à outra. O agente não percebe que ele mesmo contribui para a inteligibilidade do mundo, apesar de jamais deixar de integrá-lo espontaneamente e com a sua vontade. Há previsão porque ele age de certa

${ }^{107}$ Escritos em torno..., op. cit. p. 67 
maneira no seu mundo, e sempre esteve previsto que ele agiria de maneira contingente e livre. Todos estão num ambiente abarcado pela contingência das ações, que independe do criador, apesar da necessidade hipotética. Se a desgraça aconteceu na vida de alguém, foi porque o criador permitiu e porque o sujeito contribuiu para sua ocorrência (Th 55). Se alguém não foge da peste, ele mesmo permite que ela o assole; bastava mudar-se, disse Leibniz.

Se Judas errou, foi porque ele realmente pôde e quis. Estava previsto porque ele iria fazer e não o contrário, ou seja, ele não fez apenas pelo fato de estar previsto (DM XXX). É óbvio que ele imediatamente poderia reclamar que viera ao mundo para errar. Leibniz afirmou que de alguma forma isso é verdade ${ }^{108}$. A idéia de Judas já apresentava a traição como algo que viria a acontecer de maneira infalível. Isso não absolveria Judas? Se a ação não partisse deste, sim. Não é o que acontece. Deus tem a idéia do discípulo e já sabia que a eleição de Judas com a existência implicaria na ocorrência da traição ${ }^{109}$.

Um dos principais problemas na reclamação de Judas é a aparição tardia, depois que o pecado fora cometido, sem que nada pudesse ser feito, a não ser a condenação. Por que não reclamara antes? É certo que não faz muito sentido alguém pensar que já está condenado antes do próprio ato, principalmente diante de outras possibilidades, pois bastava fazer diferente (DM XXX). Que ele não queira realmente pecar, já seria uma outra coisa. Dificilmente quem deseja o seu bem realiza o oposto, mesmo com todas as possibilidades na sua frente. Sextus Tarquinius não deixou de dominar Roma e trazer grande desgraça para este império, mesmo depois de Júpiter ter indicado outras possibilidades que tornariam aquele mais feliz (Th 415-416). Porque queixar-se com Deus, se ele mesmo é o autor da sua condenação? Fazer diferente foi sempre concebível e realizável.

"Depende, portanto, da alma precaver-se contra as surpresas das aparências por uma firme vontade de refletir, e de nunca agir nem julgar em certas ocasiões, senão depois de ter deliberado bem maduramente. E, no entanto, verdadeiro e mesmo certo, desde toda eternidade, que nenhuma alma se há de servir deste poder em determinadas circunstâncias. Mas quem é culpado disso? E pode acaso ela queixar-se senão de si

\footnotetext{
108 “Conversasión...,", op. cit. pp.180-181. Lopes dos Santos (1998), p. 97.

109 "Conversasión...," p.182.
} 
mesma? Pois todas essas queixas depois dos acontecimentos são tão njustas quanto teriam sido antes dele" (DM XXX).

Leibniz mostrou que a criatura não age conforme um conhecimento prévio do seu futuro, como Deus conhece. Nem mesmo Deus, ser onisciente, age porque ele tem um conhecimento prévio do que ele mesmo iria fazer, o que também não teria muito cabimento $(\mathrm{C} 23)^{110}$. Ela conhece o seu futuro na medida em que o constrói. Ela não age por causa de um saber, pois ninguém conhece sua ação antes de fazê-la. Ninguém é condenado antes de cometer o erro. A ação não é comandada pelo conhecimento prévio do destino, mas antes este é construído pelas ações que serão realizadas.

Por todas essas contradições, Leibniz tentou mostrar a fonte dos erros dos pecadores. Eles percebem seus erros somente após errarem, e tentam acusar o criador quando tudo está feito. Poderiam ter feito diferente, mas não quiseram. Eles pensam que agem fora do mundo, mas não vêem que contribuem para a construção deste. Eles se preocupam com o destino apenas após o ato, e confirmam o que era previsível: que eles iriam pecar. Todavia, essas criaturas podiam agir como salvos se quisessem, pois o futuro ainda estava em aberto antes da ação. Mas como no caso de Judas e de Sextus, estavam “cegas". De onde poderiam dizer que já estavam condenados (DM XXX)? Talvez não estivessem. Eles agem na direção do futuro castigo.

Ser livre não é contrariar a ordem do mundo, mas antes segui-la da melhor maneira. Porém, respeitar a ordem do mundo não é deixar ser levado pelo fluxo, e sim acompanhá-lo pelas próprias forças e da melhor maneira. Mas mesmo aquele que não opta pelo verdadeiro bem, não deixa também de contribuir com o seu mundo, mas de maneira má, não como luz, e sim como sombra ${ }^{111}$. Há uma razão que sabe qual será a escolha, porém ela não elimina a vontade das criaturas, me smo com suas más inclinações. De fato, essas vontades também entram em harmonia.

\footnotetext{
110 Apesar de que isto gera uma grande dificuldade para Leibniz: Deus cria porque sabe que irá criar o melhor (C 23). Esse problema é ocasionado pelas principais características divinas, sua perfeição e o fato de suas operações ocorrerem fora do tempo. Como ele é perfeito, ele conhece tudo, e isso parece incluir o conhecimento da futura criação; por suas ações ocorrerem fora da temporalidade, não faria muito sentido que o processo de criação se desse de maneira sucessiva (1: reflexão sobre as possibilidades; 2: ponderação; 3 : decreto...), mas tudo deveria ocorrer de maneira imediata. Indico isto apenas para levantar o problema, mas penso não haver outra saída, a criação deve ser pensada e exprimida em etapas, pois não é fácil explicar um processo que ocorre na dimensão atemporal. O próprio Leibniz teve dificuldades em explicar o processo do decreto de maneira totalmente clara.

${ }^{111}$ Da Origem Primeira das Coisas (LP1 159).
} 
Foi visto também que havia aqueles que diziam não poder ter vontade própria, pois queriam a sua vontade, o que seria absurdo na opinião de Leibniz, pois eles não deixam de querer algo, e continuam sustentando que não seguiam suas vontades. Os homens acusam o destino de determinar suas vontades, i. é, que Deus os mandaria quererem (Conf. 80-81). Eles não percebem que ser realmente livre não é simplesmente ser dono da vontade, algo que já são, mas é saber usá-la de maneira adequada.

Como um espírito poderia corrigir tal cegueira? Eles são semelhantes ao criador em função dos seus intelectos, e isso permite a busca por um conhecimento adequado das coisas ou, como afirmou Leibniz, eles podem conhecer as verdades eternas. Eles podem conhecer as verdades absolutamente necessárias; basta ver o conhecimento teórico que eles alcançam com as ciências (Mon 29). Eles podem ter um conhecimento indutivo, como ocorre no caso das ciências da natureza. Mas eles não se limitam apenas a essa capacidade, pois os seus intelectos também podem contribuir para suas ações. Eles podem conhecer a si mesmos e o seu próprio criador, a partir das obras deste (Mon 29-30). E, por último, um espírito pode canalizar sua atenção para os seus bens e limitar a escravidão da sensibilidade.

Entretanto, essa correção não depende apenas do entendimento, pois é preciso haver uma boa vontade.

"É verdade que, graças a Deus, no que diz respeito ao mais importante, a summa rerum, a felicidade e a miséria, não carecemos de tantos conhecimentos e ajudas, como seria necessário para julgar bem em se tratando de um conselho de Estado ou de guerra, em um tribunal de justiça, em uma consulta de medicina, em uma controvérsia de teologia ou de história, ou em algum ponto da matemática ou da mecânica. Em compensação, requer-se mais firmeza de hábito no que concerne a este grande ponto da felicidade e da virtude, para tornar sempre boas resoluções e para segui-las. Em uma palavra, para verdadeira felicidade se requer menos conhecimento e mais boa vontade: assim sendo, pode atingi la facilmente tanto o maior iletrado como a pessoa mais douta" (NE II xxi 67 - grifo meu).

Judas não pecou apenas por uma falta de um entendimento purificado, mas também por uma falta de boa disposição da sua parte, ou pela sua extrema imperfeição moral. Ele tinha uma forma de conhecimento, como há em toda perseguição de um bem, mas ele se dirigiu para aquilo que estava completamente longe de ser verdadeiramente bom. Segundo Leibniz, existem criminosos que se valem da sua razão no momento de 
cometerem seus atos, pelo menos no que diz respeito aos meios de realizá-los, o que os tornam ainda mais condenáveis.

Como é possível aparecer essa boa vontade? Para uma explicação geral acerca desse assunto, seria necessário tratar dos escritos teológicos de Leibniz, o que excederia a minha proposta. De qualquer forma, para não deixar este tópico completamente vazio, Deus sempre afirmou que o primeiro passo para imitar o criador seria mudar o olhar sobre o mundo, ou melhor, seria preciso enxergá-lo como a melhor obra que já foi concebida. $\mathrm{O}$ mundo é fruto de uma arquitetura exemplar, e todos devem deleitar-se com esse fato. As falhas que aparecem no seu interior devem ser ignoradas perante o melhor dos mundos possíveis; o plano mais ordenado, que foi pensado, criado e é dirigido pelo criador (DM XXXVI - XXXVII). A partir desse pensamento, os homens podem começar a adequar os seus atos a tal estrutura. É óbvio que para que isso seja absolutamente possível, eles devem estar dispostos para essa tarefa, o que pode acontecer a partir de uma boa educação ou mesmo devido à própria graça divina. Eles também não devem sofrer de qualquer anomalia que possa interferir nos seus entendimentos. Logo, é perceptível que não basta uma correção intelectual para que aconteça uma suposta aproximação com a verdadeira Liberdade. Mas os outros detalhes acerca do uso efetivo da razão ficam para uma outra oportunidade. 


\section{LIBERDADE EM LEIBNIZ}

Leibniz nunca escondeu o que entendia por liberdade. De alguma maneira, desde os seus anos de juventude, ele já tinha em mente o que seria a melhor definição para a mesma. Mesmo que seu ponto de partida tenha sido a noção aristotélica de deliberação, ele desenvolveu uma idéia peculiar para tal conceito. Antes de chegar à definição consistente de ações livres, ele se viu obrigado a desenvolver um fundamento metafísico que se adequasse às suas intenções teológico-morais, e foi além não apenas do filósofo de Estagira, como também ultrapassou as teses de outros pensadores. Como bom filósofo, o autor da Teodicéia, mais do que se contentar com a simples reprodução do pensamento dos vários dos seus antecedentes e contemporâneos, acabou por levar o pensamento destes além do que eles mesmos poderiam imaginar; isso foi o próprio motor da filosofia leibniziana.

Não custa repetir que a resposta de Leibniz pode ser sintetizada da seguinte maneira: ser livre é agir por si na direção daquilo que é visto como um bem, sem que nada interfira na decisão do agente, senão ele mesmo, e sem que lhe seja proibido fazer diferente. Se nada impedir o agente, é certo que ele perseguirá o que lhe parece melhor. Todo esse processo é algo que pertence exclusivamente ao agente, podendo mesmo ser previsto por um ser que tenha um conhecimento perfeito das coisas, ou seja, é possível saber para onde uma criatura se dirige através da natureza desta, que opera em função da necessidade moral. No caso do criador, ele age conforme o princípio do melhor, pois sempre persegue o verdadeiro bem. Todo fato, ao final, é absolutamente inteligível; apenas uma insuficiência de conhecimento impede a compreensão $a$ priori da ação.

Observando-se a partir do seu sistema, não se pode negar que Leibniz apresenta argumentos coerentes na sua definição de liberdade. Tudo deve ter uma razão para que seja aberto um espaço para o criador, e toda ação dos espíritos deve ser sustentada em atos livres para que a responsabilidade destes seja garantida. Mesmo que a criatura racional permita a previsão divina, sua natureza de substância é fruto de suas decisões, e não de qualquer outro ser. Entretanto, alguém ainda pode defender que todo o esforço do autor desemboca na liberdade como sinônimo de ignorância. Ora, me parece que de alguma maneira isso ocorre, mas de uma forma que deve ser bem entendida, conforme o trigésimo 
artigo do Discurso de Metafísica. Ali, quando Leibniz questiona "como alguém pode saber se está condenado antes de agir?”, é algo que merece ser sublinhado. É logicamente impossível que o sujeito conheça o seu futuro antes de fazê-lo. Ele só o conhecerá em ato, construindo-o. Neste aspecto, o filósofo alemão entende que nenhum homem deve preocupar-se com o destino, que este mesmo constrói. Leibniz ainda parece radicalizar a ação conforme a razão de tal forma que mesmo se o futuro fosse apresentado previamente a alguém, este ainda realizaria o seu ato conforme o que já é indicado pela sua natureza; o exemplo de Sextus Tarquinius indica isso. O princ ipal fundamento da liberdade deveria ser sustentado principalmente na vontade do sujeito, que também constitui a natureza deste, e não na simples contingência das coisas, que poderia gerar a indiferença absoluta.

Gostaria apenas de levantar uma última questão acerca da relação entre entendimento e vontade, e sobre a verdadeira Liberdade. Leibniz mostrou que o agente sempre age em função de um bem, mesmo que seja aparente; e quem nega isso, apenas dissimula o fato de estar buscando o que lhe parece mais vantajoso (o caso de Medéia). Por outro lado, ele não deixou totalmente claro como alguém pode ter suas ações cada vez mais livres das puras aparências. $\mathrm{O}$ foco para a diminuição da escravidão é o entendimento. Mas foi visto que é preciso uma boa vontade para ativá-lo, o que parece indicar um desejo pelo próprio conhecer. É perceptível que não basta uma correção intelectual para que aconteça uma suposta aproximação com a verdadeira Liberdade. Mas, e este é o ponto da dificuldade, o bom uso do entendimento já nã o pressuporia uma escolha, o que geraria uma espécie de círculo? Afinal, onde é o ponto de partida para a correção das disposições do agente? De onde poderia surgir a boa vontade? Não se pode ignorar que Leibniz também negou que isso seja puro problema de volição, pois não se pode simplesmente querer fazer um bom uso do querer; ninguém pode querer querer, e isso parece aumentar a dificuldade. Ninguém pode querer querer melhor. Tudo isso entraria numa esfera mais profunda da formação da disposição e dos hábitos do agente; mas seria interessante entender se isso já caracteriza uma decisão ou não. Mas isso são apenas conjecturas e questões que devem ser esclarecidas em uma outra oportunidade.

Se alguém não concorda com nenhum dos argumentos de Leibniz, pelo me nos é inegável que os outros autores não saem ilesos da crítica leibniziana. Basta ver suas objeções dirigidas principalmente a Hobbes, Descartes e Espinosa. Porém, é de se 
compreender as dificuldades em se aceitar totalmente a posição de Leibniz. O futuro totalmente predeterminado associado à contingência e liberdade das ações ainda é algo não livre de complicações. Quanto ao fato do autor entender que este é o melhor dos mundos possíveis, isso nem cogitarei em tratar...

Não procurei apresentar algo no intuito de eliminar a polêmica que ocorre ao se procurar conciliar a existência do destino inflexível associada às ações livres, pois essa é uma daquelas questões que não foram feitas para serem absolutamente resolvidas, e seria um grande engano pensar que Leibniz, ou ainda pior, que eu pudesse bater o martelo para mesma. Minha principal tarefa foi mostrar como um filósofo se depara com estes grandes dilemas e a maneira como ele constrói um discurso que possa estruturar-se de maneira coerente e, portanto, ser razoavelmente aceitável. Nisso, Leibniz apresenta uma obra das mais admiráveis, pois o seu esforço discursivo é algo que facilmente chama a atenção em qualquer momento. Dizer as coisas do mundo é sempre um desafio, mas tratar os grandes dilemas é exponencialmente pior e, em muitos casos, é algo condenado à frustração. 


\section{REFERÊNCIAS BIBLIOGRÁFICAS}

1. Textos de Leibniz:

- Confessio Philosophi - La profession de foi du Philosophe, par Yvon Belaval. Paris, Ed. Vrin, 1970.

- Correspondence: G. W. Leibniz and Samuel Clarke, ed. by Roger Ariew. Indianapolis/Cambridge: Hackett Publishing, Inc, 2000.

- De Summa Rerum, Metaphysical Papers 1675-1676, Translated with an introduction and notes by G.H.R. Parkinson, New Haven and London: Yale University Press, 1992.

- Die Philosphischen Schriften von Gottfried Wilhem Leibniz, 7vols, Gerhardt. Hildeshein: Olms, 1961.

- Discours de Métaphysique, Mnadologie et autres textses, édeition établie, présentée et annptée par Michel Fichant. Paris : Éditions Gallimard, 2004.

- Discurse on Metaphysics and other essays, ed. and trad. by Daniel Garber. Indianapolis/Cambridge: Hackett Publishing, Inc, 1991.

- Discurso de Metafísica e outros escritos, apresentação e notas de Tessa M. Lacerda. São Paulo: Martins Fontes, 2004.

- Les deux labyrintes, textes choisis par Alain Chauve, Paris: PUF, 1973.

- G. W. Leibniz's Monadology, ed. and coment. Nicolas Rescher.

- Escritos en torno a la libertad, el azar e el destino, estudio preliminar y notas de Concha R. Panadero. Madrid: Ed. Tecnos, 1990.

- Escritos Filososficos, edición de Ezequiel de Olaso. Buenos Aires: Editorial Charcas, 1982.

- Essais de Théodicée, ed. par J. Brunschwig. Paris, Garnier-Flammarion, 1969 ; ou em: GPVI.

- Filosofia para Princesas, prólogo, edición y notas de Javier Echeverría. Madrid: Alianza Editorial, 1989.

- Leibniz lexicon : a dual concordance to Leibniz's Philosophiche Schriften, compiled by Reinhard Finster ... [et al.]. Hildesheim; New York: Olms-Weidmann, 1988.

- Leibniz`s Monadology, ed. by Nicolas Rescher. University of Pittisburg Press, 1999. 
- I. Newton e G. W. Leibniz :Coleção Os Pensadores. São Paulo: Abril Cultura, 1979.

- Novos Ensaios sobre o Entendimento Humano, trad. Luiz João Baraúna. São Paulo: Nova Cultural, 1999.

- Oeuvres de G. W. Leibniz, tome I, ed. Par Lucy Prenant. Paris: Ed.Aubier Montaigne, 1972.

- Philosophical Essays, translated by R. Ariew and D. Garber. Indianapolis: Hackett Publishing Copany Inc, 1989.

- "Primae veritates", in: Couturat (1995).

- Opuscules et fragments inédits de Leibniz, org. Par L. Couturat, Paris: Félix Alcan Éditeur, 1903.

- Philosophical Essays, trad. and ed. by Roger Ariew and Daniel Garber. Indianapolis/Cambridge: Hackett Publishing, Inc, 1989.

- Philosophical papers and letters, ed. Leroy E. Loemker. Dordrecht- Holland: D. Reidel Publishing Company, (1969) 1976.

- Recherches générales sur l'analyse des notions et des vérités 24 thèses métaphysiques, ed. Michel Fichant. Paris, PUF, 1998.

- Réfutatio inédite de Spinoza, lecture et appareil critique de Martine de Gaudemar. Paris: Babel, 1999.

- Sämtliche Schriften und Briefe, hrsg. von der Preussischen, bzw. der Deutschen Akademie der Wissenschaften zu Berlin. Darmstadt, 1923 ss., Leipzig, 1938, Berlin, 1950 ss.

- Sistema Novo da natureza e da comunicação das substâncias e outros textos, seleção e tradução de Edgar Marques, Belo Horizonte: Ed. Da UFMG, 2002.

- Système Nouveau de la nature et de la communication des substances et autres textes (1690-1703), présentation et notes de Christiane Frémont. Paris :GF-Flammarion,1994.

- Textes inédits : d'après les manuscrits de la Bibliothèque provinciale de Hanovre, publiés et annotés par Gaston Grua. Paris: PUF, 1998, c1948.

2. Outras obras, comentadores e artigos:

ADAMS, R. M., “Leibniz's Theories of Contingency”. In: Whoolhouse, R. S.(1993), 128173. 
, Leibniz : Determinist, Theist, Idealist. New York, Oxford University Press, 1994.

"Moral Necessity". In: Ruthefor (2005), 181-193.

ARISTOTE, Catégories, presentation, traduction et commentaries de Frédérique Ildefonse er Jean Lallot. Paris : Éditions du Seuil, 2002.

ARISTOTLE, The Complete Works of Aristotle, 2 vols., ed. by Jonathan Barnes. Princeton/ New Jersey: Princeton University Press, 1984.

, The Basic Works, edited by Richard McKeon. New York: The Modern Library, 2001.

AUBENQUE, P., A Prudência em Aristóteles, trad. de Marisa Lopes. São Paulo: 2003.

BELAVAL, Y., Leibniz Critique de Descartes. Paris : Édition Gallimard, 1960. , Leibniz: Initiation a sa philosphie. Paris : Vrin, 1962.

COTTINGHAM, J., The Rationalists. Oxfor/ New York : Oxfor University Press, 1988.

COUTURAT, L., "Sur la métaphisique de Leibniz". In: Revue de Métaphisique et de Moral, Paris, ${ }^{\circ} 1$ (1995), 13-30.

FICHANT, M., "Da Substância Individual à Mônada”. In: Analytica, vol.5, nº1-2 (2000), 1134. , "L'origine de la négation". In: M. Fichant (1998), . , Science et métaphysique dans Descartes et Leibniz. Paris: PUF, 1998.

FORLIN, E Jr., A teoria cartesiana da verdade. Tese de Doutoramento defendida no Dep. Filosofia - FFLCH - USP, São Paulo, 2000.

FRANKEL, L., "Being Able to do Otherwise: Leibniz on Freedom and Contingency". In: Whoolhouse, R. S. (1993), 284-302.

GARBER, D., "Motion and Metaphysics in the Young Leibniz. In: Hooker, M. (1982). "L'origine de la negation".

GAUDEMAR, M., "Réfutation ou Confrontation? Les périls d'une rencontre: Leibniz au risque du spinozisme”. In: Réfutation inédite de Spinoza (1999), 59-96.

GUEROULT, M., Etudes sur Descartes, Spinoza, Malebranche et Leibniz. New York: Georg Olms Verlag Hildesheim, 1970.

HOOKER, M. (ed.), Leibniz: Critical and Interpretive Essays. Minneapolis: University of Minnesota Press, 1982. 
JOLLEY, N., Leibniz. New York, Routledge, 2005.

,(ed.), The Cambrige Companion to Leibniz. San Diego: Cambridge University Press, 1995.

KNEALE, W AND M., “O desenvolvimento da Lógica”, trad. M. S. Lourenço. Lisboa: Fundação Calouste Gulbenkian, 1991.

LEBRUN, G., "O conceito de Paixão". In: Novaes, A (org.), Os Sentidos da Paixão. São Paulo: Funarte/Companhia das Letras, 1986.

LEINKAUF, T., "Gottfried Wilhelm Leibniz - Transformação sistemática da substância: unidade, força, espírito”. In: Kreimendahl, L. (org.), Filósofos do século XVII, São Leopoldo (RS): Editora Unisinos (2003), 260-290.

LOPES DOS SANTOS, L.H., "Anotações sobre Leibniz, o Estoicismo, Substâncias e Labirintos”. In: MARQUES, E.(1999), 389-400.

, "Leibniz e a Questão dos Futuros Contingentes", in Analytica, vol.3, n¹, (1998), 91-121.

MADOUAS, S., "L' Adam vague et la constituition des mondes possibles: une pensée de l'individu". In: Berlioz, D. (ed.), L'Actualité de Leibniz: Les Deux Labyrinthes, Studia Leibinitiana Supplementa, Stuttgart. Franz-Steiner Verlag, n³4 (1999), 363-388.

MARQUES, E., “Apresentação". In: Sistema novo da natureza e da comunicação das substâncias e outros textos, apresentação, seleção e tradução de Edgar Marques, Belo Horizonte: Ed. Da UFMG, 2002. , "Necessidade e Contingência em Leibniz e Arnauld". In: Kriterion, Belo Horizonte, vol. XXXIX, n97 (1998), 212-226. , “A Noção de 'Possível em Si' e a Solução Leibniziana do Problema da Liberdade", in Analytica, vol.5, n 1-2 (2000), 35-48. (org.), Verdade, conhecimento e ação, Ensaios em Homenagem a Guido Antônio de Almeida e Raul Landim F. São Paulo: Loyola (1999), 389-400.

MERCER, C. and SLEIGH JR., R. C., "The early period to the Discource on Metaphysics". In: Jolley, N. (1995).

MONDADORI, F., "Leibniz and the Doctrine of Inter-World Identiry". In:

Whoolhouse, R. S. (1993), 257-289. 
MOURA, C.A.R., "A indiferença e a balança". In: Évora, F., Lógica e Ontologia: Ensaios em homenagem a Balthazar Barbosa Filho. São Paulo: Discurso Editorial (2004), 245262.

, “Contingência e Infinito". In: Racionalidade e Crise. São Paulo: Discurso Editorial e UFPR, 2001.

, "Leibniz, a Liberdade e os Possíveis", Coleção CLE, vol.36 (2003), 268-283.

MONDADORI, F., “Leibniz and the Doctrine of Inter-World Identiry”. In:

Whoolhouse, R. S. (1993), 257-289.

MURRAY, M. J., "Spontaneity and Freedom in Leibniz”. In: Routheford, D. and Cover, J. A. (2005).

PARKINSON, G.H.R., Logic and Reality in Leibniz's Metaphysics. Oxford Univesity Press, 1965.

PINHEIRO, U., “Contingência e Análise Infinita em Leibniz”. In: Kriterion, Belo Horizonte, vol. XXXIX, n97 (1998),

RESCHER, N., "Contingence in the philosophy of Leibniz". In: The Philosophical Review, vol. 61, n¹ (jan. 1952), 72-96.

RUSSEL, B., A critical exposition of the philosophy of Leibniz. London: Allen \& Unwin, 1958.

RUTHEFORD, D., Leibniz and the rational order of nature. Cambridge University Press: 1998.

RUTHEFORD, D and COVER, J. A., Leibniz: Nature and Freedom. Oxfor Univesity Press: 2005.

SLEIGH JR, R.C., Leibniz and Arnaud: a commentary on their correspondence. New Haven and London: Yale University Press, 1990.

, “Leibniz's First Theodicy". In: Philosophical Perspectives, 10, Metaphysics (1996), 481-499.

VAILATI, E., Leibniz \& Clarke : a study of their correspondence. New York : Oxford University Press, 1997

WILSON, C., Leibniz's metaphysics. Princeton, N.J. : Princeton University Press, 1989.

WOOLHOUSE, R.S., Gottfried Wilhelm Leibniz: Critical assentments, 4vol. London an New York: Routledge, 1993. 